$$
\text { UNIVERSIDADE DE SÃO PAULO }
$$

FACULDADE DE ZOOTECNIA E ENGENHARIA DE ALIMENTOS

\author{
Camila Velludo Molina
}

\title{
BETA-CAROTENO ENCAPSULADO EM MICROPARTÍCULAS LIPÍDICAS SÓLIDAS: AVALIAÇÃO TECNOLÓGICA E SENSORIAL DA INCORPORAÇÃO EM IOGURTE
}


Camila Velludo Molina

\title{
BETA-CAROTENO ENCAPSULADO EM MICROPARTÍCULAS LIPÍDICAS SÓLIDAS: AVALIAÇÃO TECNOLÓGICA E SENSORIAL DA INCORPORAÇÃO EM IOGURTE
}

\author{
VERSÃO CORRIGIDA
}

Dissertação apresentada à Faculdade de Zootecnia e Engenharia de Alimentos da Universidade de São Paulo, como parte dos requisitos para a obtenção do Título de Mestre em Ciências.

Área de concentração: Ciências da Engenharia de Alimentos

Orientadora: Prof. ${ }^{a}$ Dr. ${ }^{a}$ Samantha Cristina de Pinho 
Dados Internacionais de Catalogação na Publicação

Serviço de Biblioteca e Informação da Faculdade de Zootecnia e Engenharia de Alimentos da Universidade de São Paulo

Molina, Camila Velludo
Beta-caroteno encapsulado em micropartículas

lipídicas sólidas: avaliação tecnológica e sensorial da

Incorporação em iogurte / Camila Velludo Molina. --

Pirassununga, 2014

$96 \mathrm{f}$.

Dissertação (Mestrado) -- Faculdade de Zootecnia e

Engenharia de Alimentos - Universidade de São Paulo.

Departamento de Engenharia de Alimentos.

Área de Concentração: Ciências da Engenharia de Alimentos.

Orientadora: Profa. Dra. Samantha Cristina de Pinho.

1. Beta-caroteno 2. Microencapsulação

3. Micropartículas lipídicas sólidas 4. Iogurte.

I. Título. 
A minha filha "meu amor maior do que o universo": Laura E ao meu companheiro, incentivador e inspirador, José Antonio Dedico tudo isso e muito mais.

Amo vocês. 


\section{AGRADECIMENTOS}

À minha orientadora, Prof ${ }^{\mathrm{a} .}$ Dr $^{\mathrm{a}}$ Samantha Cristina de Pinho, por assumir a orientação deste trabalho com extrema dedicação e comprometimento. Sou grata por ter aceitado dividir comigo o gosto por desafios. Obrigada pela sua generosidade e amizade.

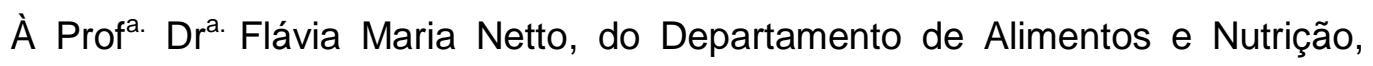
Faculdade de Engenharia de Alimentos da UNICAMP, pelo grande auxílio na condução dos trabalhos de caracterização proteica.

À MSc. Eliana Pettiroussi do Laboratório de Fontes Proteicas (LAFOP/ FEA/UNICAMP), pela ajuda com as análises de caracterização do isolado proteico de soja.

À Prof ${ }^{a}$ Dr. Izabel C.F. Moraes pela ajuda com as análises reológicas.

À Prof ${ }^{\text {a. }}$ Dr $^{\text {a. }}$ Rose Naal da FCFRP / USP e técnica MSc. Laila Deliberto pela ajuda nas análises espectrofluorimétricas.

À Ana Monica, Edneli e Carla pela ajuda com os ensaios de DSC, colorimetria e tensão interfacial.

À Agropalma pela doação da estearina de palma refinada.

À Danisco pela doação da goma xantana.

À Liotécnica pela doação da cenoura desidratada.

À Symrise Aromas e Fragrâncias, e às Engenheiras de Alimentos Cíntia Ribeiro Schimming e Beatriz Ott Andrade, pela doação dos aromas de mel e laranja.

A Prefeitura do Campus da USP de Pirassununga/PUSP-P e Faculdade de Zootecnia e Engenharia de Alimentos/FZEA, das quais fiz e faço parte do quadro funcional, respectivamente, pela liberação concedida para realização deste trabalho.

À Seção de Laticínios/PUSP-P pela doação das matérias-primas e pela dedicação do Sr. Osvaldo e funcionária Silvia, na fabricação dos iogurtes.

Às alunas de graduação Thais Carvalho Brito e Juliana Gobbi de Lima, pela persistência e eficiência na execução dos trabalhos.

Aos amigos e colegas de Laboratório de Coloides/ZEA, em especial: Marília, Taíse, Grazi, Thais Borrin, Matheus, Camila Cazado, Caio e Marluci por todo o apoio, pelos momentos em que dividimos nossas dúvidas cotidianas e coloidianas ("será que está estável?"), pelas troca de ideias produtivas que tais dúvidas nos proporcionavam, pelas risadas, pelo apoio imprescindível nas análises sensoriais, (e pelos selfies depois), pelos seminários com confraternizações gastronômicas às sextas-feiras e muito mais... 
Ao CNPq pelo financiamento do projeto de Pesquisa (Edital Universal, processo 471689/2012-2),

Muito obrigada a todos que me ajudaram a conferir a esse trabalho todo valor e significado que ele tem. 


\section{RESUMO}

MOLINA, C.V. BETA-CAROTENO ENCAPSULADO EM MICROPARTÍCULAS LIPÍDICAS SÓLIDAS: AVALIAÇÃO TECNOLÓGICA E SENSORIAL DA INCORPORAÇÃO EM IOGURTE. 2014. 91f. Dissertação (Mestrado) - Faculdade de Zootecnia e Engenharia de Alimentos, Universidade de São Paulo, Pirassununga, 2014.

O beta-caroteno é uma substância lipofílica com características nutricionais importantes, mas devido a sua susceptibilidade à degradação, sua ingestão diária pode ficar comprometida. O sistema de encapsulação em micropartículas lipídicas sólidas pode ser uma alternativa para solucionar essa questão, por possuir a propriedade de liberação controlada do bioativo, que aumenta a biodisponibilidade no organismo humano, entre outras qualidades. Existem questões a serem elucidadas acerca da estrutura, modo de preparo e a aplicabilidade de sistemas de micropartículas lipídicas sólidas, e para isso foram testadas formulações utilizando como lipídio sólido a estearina de palma. O tensoativo utilizado neste trabalho foi o isolado proteico de soja, que foi disperso em água deionizada e submetido a tratamento térmico em diferentes condições de pH. Estas dispersões foram caracterizadas quanto ao potencial zeta, tensão interfacial em contato com a estearina de palma, hidrofobicidade superficial, perfil de aminoácidos, caracterização de frações proteicas por meio de eletroforese (SDS-PAGE), calorimetria diferencial de varredura e difratometria em raios-X. A caracterização físico-química dos sistemas de micropartículas foi realizada através de ensaios de distribuição de tamanho de partícula, potencial zeta e concentração de beta-caroteno. Estes ensaios objetivaram avaliar a viabilidade da aplicação na indústria de alimentos, mais especificamente, de sua incorporação em iogurte. Os iogurtes aplicados de micropartículas lipídicas sólidas encapsulando beta-caroteno foram analisados em termos de colorimetria instrumental, análises de $\mathrm{pH}$, acidez, teor de gordura, proteína, densidade, reologia e avaliação de aceitação sensorial. Os resultados obtidos mostraram a possibilidade de estabilização de sistemas com as dispersões de isolado proteico. As dispersões que obtiveram melhor desempenho foram as submetidas a tratamento térmico em $\mathrm{pH} 12$. Os indicaram alta viabilidade de aplicação, especialmente para os sistemas contendo alfatocoferol.

Palavras-chave: beta-caroteno, microencapsulação, micropartículas lipídicas sólidas, iogurte. 


\section{ABSTRACT}

MOLINA, C.V. ENCAPSULATED BETA-CAROTENE IN SOLID LIPID MICROPARTICLES: TECHNOLOGICAL AND SENSORY ASSESSEMNT OF ITS INCORPORATION IN YOGHURT. 2014. 91f. M. Sc. Dissertation - Faculdade de Zootecnia e Engenharia de Alimentos, Universidade de São Paulo, Pirassununga, 2014.

Beta-carotene is a hydrophobic bioactive compound with important nutritional value but its high tendency to degradation can reduce its health benefits related to dietary intake. Encapsulation lipid carriers such as solid lipid microparticles (SLM) are feasible alternatives to solve this issue, for example, by increasing its bioavailability. There are many questions about structure, formulation and procedures to be answered and also about its feasibility of application on food products. Aiming at answering some of those questions, this present study tested palm stearin as a solid lipid for the formulations. Soy protein isolate dispersed in deionized water at $\mathrm{pH}$ ranging from 3 to 12 were prepared and tested by zeta potential, surface tension in contact with palm stearin, surface hydrophobicity, aminoacids profile, electrophoresis (SDS-PAGE), differential scanning calorimetry (DSC) and Fourier transform infrared spectroscopy. Physicochemical characterization of the SLM systems loaded with beta-carotene was done by particle size, zeta potential and beta-carotene concentration. Aforesaid studies aimed at improving our understanding about the physicochemical stability of those systems and also at evaluating the viability of their incorporation in stirred yoghurt. Different formulations of yoghurt were manufactured and tested by colorimetric analysis, $\mathrm{pH}$, titratable acidity in lactic acid, lipids and protein concentrations, density, rheology and sensory acceptance trials. The results were significantly positive. For the soy protein isolate analysis, the dispersions produced by thermal treatment under alkaline ph (namely, $\mathrm{pH} 12$ ) had the best performance. Concerning the SLM systems incorporated in yoghurt, further interesting results were found. Yoghurts produced with SLM added to alpha-tocopherol (alfa-tocopherol:beta-carotene concentrations of 1:2 and 1:1) were significantly better from those without alpha-tocopherol regarding colour stability for the observation period of 25 days. Future extensions may focus on enhancing beta-carotene loads to SLM systems as well as on testing the incorporation of SLM systems (or their adaptations) in other food products, particularly those requiring additional colour intensity.

Keywords: beta-carotene, microencapsulation, solid lipid microparticles, yoghurt. 


\section{LISTA DE FIGURAS}

Figura 1. Exemplos de estrutura de sistemas encapsulantes lipídicos (adaptado de GONNET et al., 2010)

Figura 2. Exemplos de estruturas encontradas em sistemas lipídicos de encapsulação (adaptado de MCCLEMENTS E LI, 2010).

Figura 3. Esquema simplificado de uma partícula lipídica sólida. 24

Figura 4. Modelos de incorporação de compostos ativos em partículas lipídicas sólidas: (a) matriz homogênea; (b) parede enriquecida e (c) núcleo enriquecido (fonte: SOUTO, 2006)

Figura 5. Estruturas moleculares de carotenoides pró-vitamínicos. (adaptado de Damodaram et al., 2010).

Figura 6. Diagrama de fluxo do protocolo utilizado para dispersão do isolado proteico de soja em água.

Figura 7. Representação esquemática do protocolo experimental utilizado para produção das micropartículas lipídicas.

Figura 8. Fluxograma de produção do iogurte adicionado de micropartículas lipídicas encapsulando beta-caroteno.

Figura 9. Valores de potencial zeta para amostras de dispersões de isolado proteico de soja após tratamento alcalino-térmico.

Figura 10. Eletroforese em gel de poliacrilamida na presença de SDS de amostras de isolado proteico de soja original e após tratamento alcalino-térmico. 52

Figura 11. Espectros de infravermelho obtidos por FT-IR para amostra de isolado proteico de soja original e após tratamento alcalino-térmico.

Figura 12. Fórmula estrutural do ácido 8-anilino-1-naftalenosulfônico. Fonte: SigmaAldrich (2014) 55

Figura 13. Curvas de intensidade de fluorescência obtidas no ensaio de hidrofobicidade superficial para amostras de isolado proteico de soja original............56 Figura 14. Curvas de intensidade de fluorescência obtidas no ensaio de hidrofobicidade superficial para amostras de isolado proteico de soja tratado, dispersas em $\mathrm{pH} 12$. . 56

Figura 15. Curvas de intensidade de fluorescência obtidas no ensaio de hidrofobicidade superficial para amostras de isolado proteico de soja tratado, dispersas em $\mathrm{pH} 9$. 
Figura 16. Curvas obtidas do ensaio de hidrofobicidade superficial para amostras de IPS original (n), tratados com pH 9 (9) e pH 12 (12), ambos a 0,1 g/L de teor proteico dos sobrenadantes.

Figura 17. Composição em aminoácidos totais em amostras de isolado proteico de soja original e após tratamento alcalino-térmico.

Figura 18. Termogramas obtidos por calorimetria diferencial de varredura para 0 isolado proteico de soja original e tratado em $\mathrm{pH} 12$.

Figura 19. Difratograma de raios-X da estearina de palma pura.

Figura 20. Termograma obtido por calorimetria diferencial de varredura para a estearina de palma pura.

Figura 21. Aspecto visual das micropartículas lipídicas sólidas encapsulando betacaroteno.

Figura 22. Curvas de distribuição de tamanho das micropartículas lipídicas sólidas formulação 1 (sem tocoferol).

Figura 23. Curvas de distribuição de tamanho de das micropartículas lipídicas sólidas - formulação 2 (razão 2:1 beta-caroteno:tocoferol).

Figura 24. Curvas de distribuição de tamanho de das micropartículas lipídicas sólidas - formulação 3 (razão 1:1 beta-caroteno:tocoferol)

Figura 25. Valores de potencial zeta obtidos para as micropartículas lipídicas ao longo do tempo de armazenagem.

Figura 26. Perfil temporal de concentração de beta-caroteno nas dispersões de micropartículas lipídicas sólidas com diferentes proporções de alfa-tocoferol: Formulações 1, 2 e 3.

Figura 27. Imagens de amostras de amostras de iogurtes comerciais sabor cenoura, laranja e mel

Figura 28. Parâmetros colorimétricos $L^{*} a^{*} b^{*}$ das amostras de iogurte em comparação com os produtos comerciais.

Figura 29. logurtes produzidos com partículas lipídicas com formulação sem alfatocoferol (1), com 1:2 de alfa-tocoferol: beta-caroteno (2) e 1:1(3) de alfa-tocoferol: beta-caroteno, no dia da produção (dia 0).

Figura 30. logurtes produzidos com partículas lipídicas com formulação sem alfatocoferol (logurte 1), com 1:2 de alfa-tocoferol: beta-caroteno (logurte 2) e 1:1 (logurte 3) de alfa-tocoferol: beta-caroteno, no $15^{\circ}$ dia de estocagem.

Figura 31. Valores de pH de amostras dos iogurtes produzidos, ao longo do período de armazenagem. 
Figura 32. Valores de acidez titulável de amostras dos iogurtes produzidos, ao longo do tempo de armazenagem.

Figura 33. Parâmetros colorimétricos $L^{*}, a^{*} e b^{*}$ obtidos para as amostras de iogurte produzidos, ao longo do tempo de armazenagem.

Figura 34. Valores dos parâmetros croma e ângulo de hue para as amostras de iogurte produzidos, ao longo do tempo de armazenagem. 72

Figura 35. Diferença total de cor para as amostras de iogurte produzidos, ao longo do tempo de armazenagem. 73

Figura 36. Curvas de fluxo para amostras de iogurtes - dia 0 (A), dia 15 (B) e dia 25 (C). 74

Figura 37. Valores de tixotropia dos iogurtes produzidos. 76

Figura 38. Notas atribuídas para os diferentes atributos avaliados na análise sensorial dos iogurtes produzidos com micropartículas lipídicas sólidas encapsulando betacaroteno : (a) cor; (b) textura; (c) sabor; (d) aceitação global. 


\section{LISTA DE TABELAS}

Tabela 1. Exemplos de estudos encontrados na literatura empregando micro e nanopartículas lipídicas sólidas para encapsulação de bioativos de interesse na área alimentícia.

Tabela 2. Parâmetros físico-químicos do iogurte exigidos pela legislação (BRASIL, 2007).

Tabela 3. Perfil de ácidos graxos de amostras de óleo, estearina e oleína de palma (adaptado de Kalustian, 1985).

Tabela 4. Composições dos geis de separação, empacotamento e tampão redutor de amostra.

Tabela 5. Parâmetros utilizados para dispersão de isolado proteico de soja em água.

Tabela 6. Formulações utilizadas para produção das micropartículas lipídicas. 45

Tabela 7. Formulação do iogurte branco.

Tabela 8. Formulação dos iogurtes com adição de partículas lipídicas sólidas encapsulando beta-caroteno produzidos.

Tabela 9. Composição centesimal do isolado proteico de soja empregado neste trabalho de Mestrado.

Tabela 10. Posições das bandas encontradas nos espectros de infravermelho dos isolados proteicos de soja original e tratado. 54

Tabela 11. Concentrações proteicas do sobrenadante das soluções após centrifugação utilizadas nos ensaios de hidrofobicidade superficial.

Tabela 12. Valores de tensão interfacial entre as fases oleosa (estearina de palma a $85^{\circ} \mathrm{C}$ ) e aquosa, utilizando-se como tensoativo dispersões de IPS após tratamento alcalino-térmico, em diferentes valores de $\mathrm{pH}$.

Tabela 13. Caracterização físico-química dos iogurtes produzidos neste trabalho de Mestrado. 70

Tabela 14. Parâmetros reológicos $\tau_{0}$ (tensão de cisalhamento inicial), $k$ (índice de consistência) e $\mathrm{n}$ (índice de comportamento do fluido) obtidos. .75

Tabela 15. Valores de viscosidade aparente de amostras dos iogurtes produzidos....76 


\section{LISTA DE SIGLAS E ABREVIAÇÕES}

ANS - ácido 8-anilino-1-naftalenosulfônico

AAAB - ácido a-aminobutírico

BHT - di-terc-butil metil fenol

DLS - Dynamic Light Scattering / Espalhamento dinâmico de luz

FT-IR - Fourier transform infrared spectroscopy / Espectroscopia no infravermelho com transformada de Fourier

HPLC - High-performance liquid chromatography / Cromatografia líquida de alta eficiência

IPS - isolado proteico de soja

MLS - micropartículas lipídicas sólidas

PITC - Phenyl isothiocyanate / Fenil isotiocianato

SDS - sodium dodecil sulphate / dodecil sulfato de sódio

SDS-PAGE - Sodium Dodecyl Sulfate - Polyacrylamide Gel Electrophoresis /

Eletroforese em gel de poliacrilamida

SLN - solid lipid nanoparticle / nanopartícula lipídica sólida

TEMED - tetrametilenodiamina

TCD - Diferença total de cor

UV - Ultravioleta 


\section{LISTA DE SÍMBOLOS}

$\mathrm{a}^{*}=$ cromaticidade no eixo variando do vermelho/verde

$b^{*}=$ cromaticidade no eixo variando do amarelo/azul

$\dot{\gamma}=$ taxa de deformação $\left(\mathrm{s}^{-1}\right)$

$\Delta \mathrm{H}=$ entalpia de transição de fases

$\mathrm{k}=$ índice de consistência $\left(\mathrm{Pa} . \mathrm{s}^{\mathrm{n}}\right)$

$\mathrm{L}^{*}=$ luminosidade

$\mathrm{n}=$ índice de comportamento (adimensional)

$\tau=$ tensão de cisalhamento $(\mathrm{Pa})$

$\tau_{0}=$ tensão de cisalhamento inicial $(\mathrm{Pa})$ 


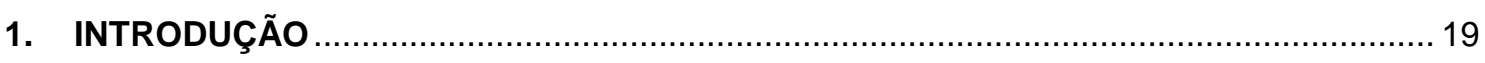

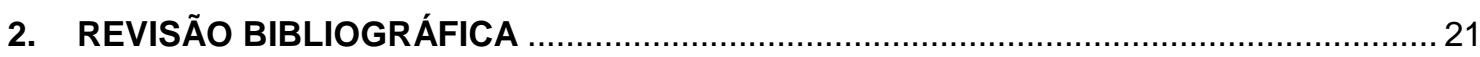

2.1 MICRO E NANOENCAPSULAÇÃO DE BIOATIVOS ALIMENTÍCIOS …......................2 21

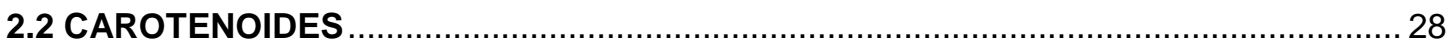

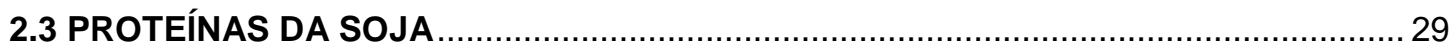

2.4 IOGURTE

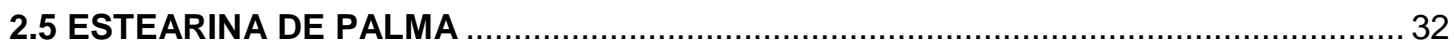

3. OBJETIVOS

4. MATERIAIS

4.1 CARACTERIZAÇÃO DO ISOLADO PROTEICO DE SOJA E PRODUÇÃO DAS

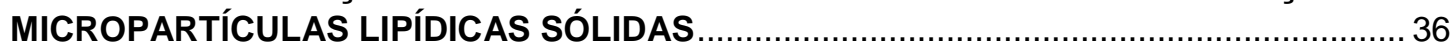

4.2 PRODUÇÃO E CARACTERIZAÇÃO DE IOGURTE ADICIONADO COM BETACAROTENO ENCAPSULADO EM MICROPARTÍCULAS LIPÍDICAS SÓLIDAS …..............37

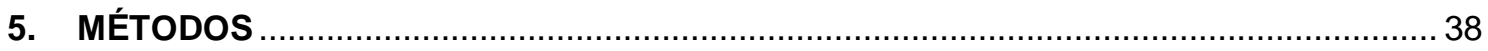

5.1 COMPOSIÇÃO CENTESIMAL DO ISOLADO PROTEICO DE SOJA.............................38

5.1.1. DETERMINAÇÃO DA PORCENTAGEM DE PROTEÍNA …............................... 38

5.1.2. DETERMINAÇÃO DO TEOR LIPÍDICO........................................................... 38

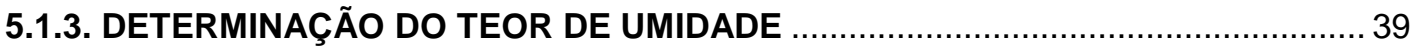

5.2 CARACTERIZAÇÃO E PRODUÇÃO DAS DISPERSÕES DE ISOLADO PROTEICO DE

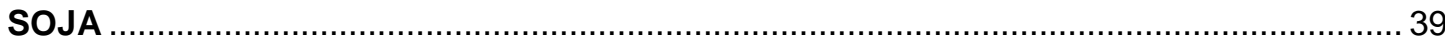

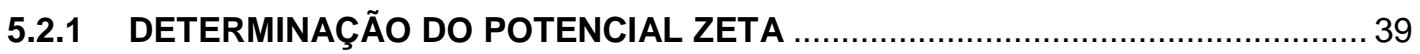

5.2.2. ELETROFORESE EM GEL DE POLIACRILMIDA (SDS-PAGE)............................ 39

5.2.3. ESPECTROSCOPIA DE INFRAVERMELHO COM TRANSFORMADA DE

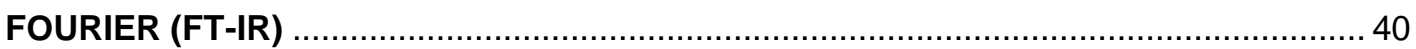

5.2.4. DETERMINAÇÃO DA HIDROFOBICIDADE SUPERFICIAL ............................... 40

5.2.5. DETERMINAÇÃO DO PERFIL DE AMINOÁCIDOS TOTAIS ................................ 41

5.2.6. DETERMINAÇÃO DA TENSÃO INTERFACIAL ENTRE DISPERSÃO DE ISOLADO

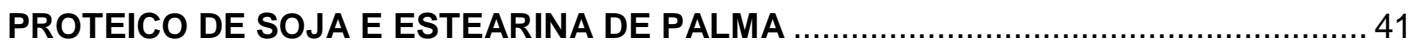

5.2.7. PRODUÇÃO DAS DISPERSÕES DE ISOLADO PROTEICO DE SOJA................. 42

5.3 CARACTERIZAÇÃO FÍSICO-QUÍMICA DA ESTEARINA DE PALMA …................ 43

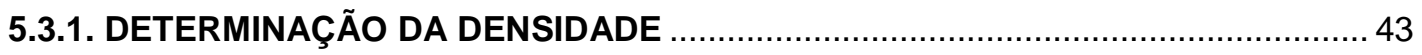

5.3.2. CALORIMETRIA DIFERENCIAL DE VARREDURA (DSC) .............................. 43

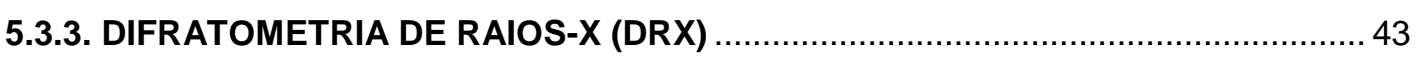

5.4 PRODUÇÃO E CARACTERIZAÇÃO DAS MICROPARTíCULAS LIPÍDICAS

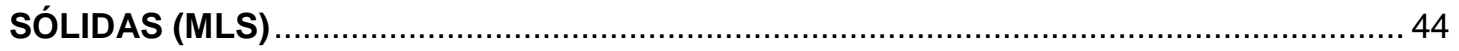

5.4.1. DETERMINAÇÃO DAS DISTRIBUIÇÕES DE TAMANHO DE PARTíCULA ........... 44

5.4.2. QUANTIFICAÇÃO DO BETA-CAROTENO ENCAPSULADO ............................... 44

5.4.3. CALORIMETRIA DIFERENCIAL DE VARREDURA (DSC) ............................... 44 
5.4.4. PRODUÇÃO DAS MICROPARTÍCULAS LIPÍDICAS

5.5 PRODUÇÃo E CARACTERIZAÇÃo DE IOGURTE ADICIONADO DE BETA-

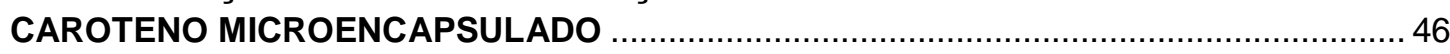

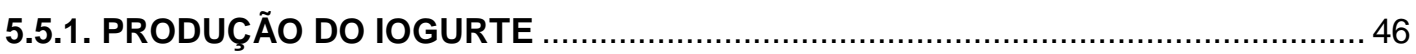

5.5.2. CARACTERIZAÇÃO FÍSICO-QUÍMICA E MONITORAMENTO DA ESTABILIDADE DOS IOGURTES

5.5.3. AVALIAÇÃO SENSORIAL DOS IOGURTES ................................................ 47

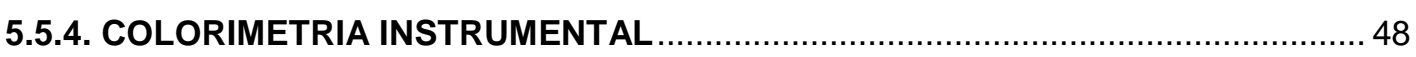

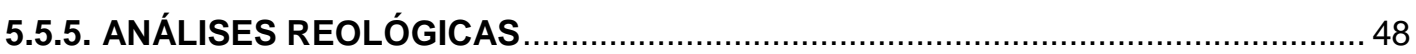

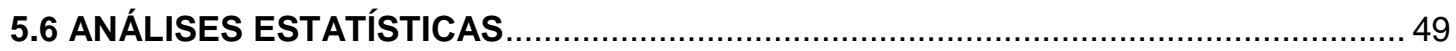

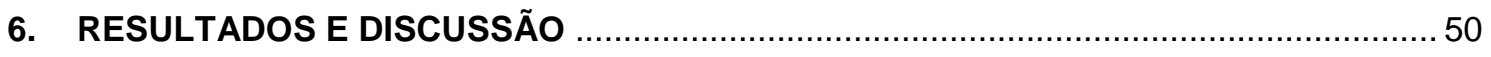

6.1. CARACTERIZAÇÃO DO ISOLADO PROTEICO DE SOJA …................................... 50

6.1.1. COMPOSIÇÃO CENTESIMAL DO ISOLADO PROTEICO DE SOJA .....................50

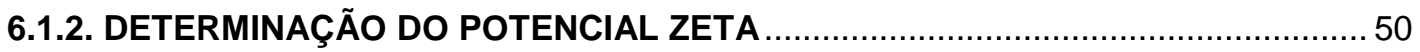

6.1.3. ELETROFORESE EM GEL DE POLIACRILAMIDA (SDS-PAGE) ….................. 52

6.1.4. ESPECTROSCOPIA DE INFRAVERMELHO COM TRANSFORMADA DE

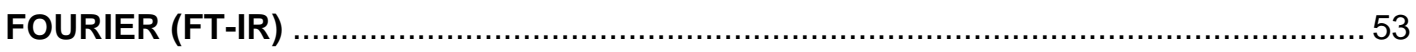

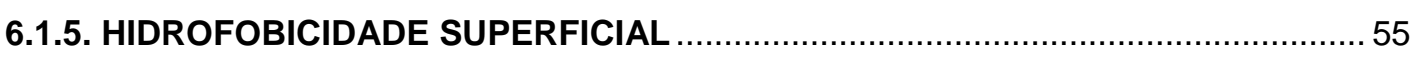

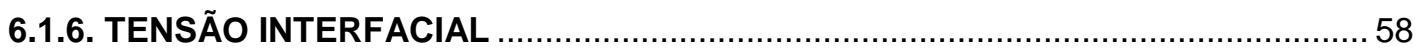

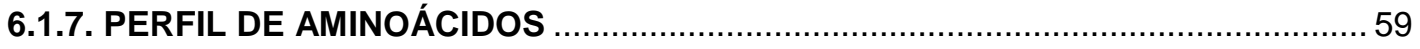

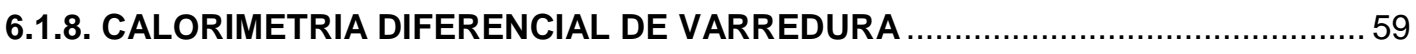

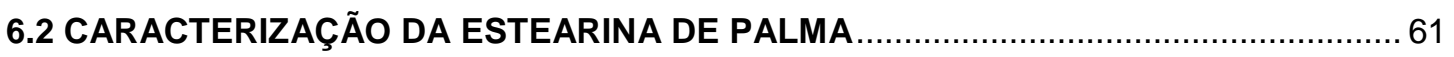

6.3 CARACTERIZAÇÃO FÍSICO-QUÍMICA E MONITORAMENTO DA ESTABILIDADE DAS

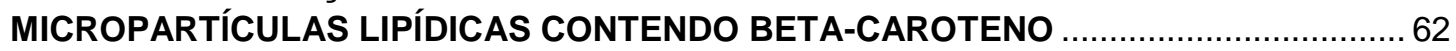

6.4. INCORPORAÇÃO DE MICROPARTÍCULAS LIPÍDICAS SÓLIDAS ENCAPSULANDO

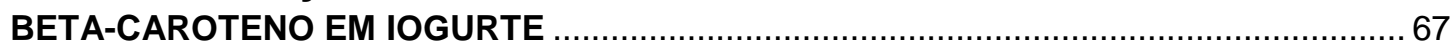

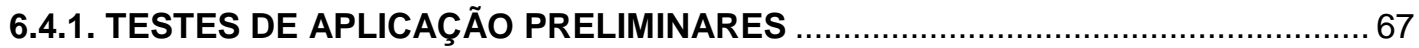

6.4.2. DETERMINAÇÃO DE DENSIDADE, GORDURA, PROTEínA E UMIDADE NOS

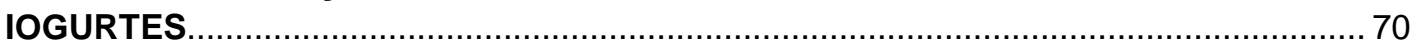

6.4.3. DETERMINAÇÃO DE ACIDEZ EM ÁCIDO LÁTICO E PH ................................. 70

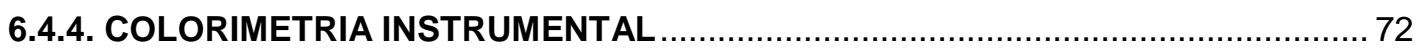

6.4.5. DETERMINAÇÃO DOS PARÂMETROS REOLÓGICOS .................................... 73

6.4.6. AVALIAÇÃO SENSORIAL DOS IOGURTES .............................................. 77

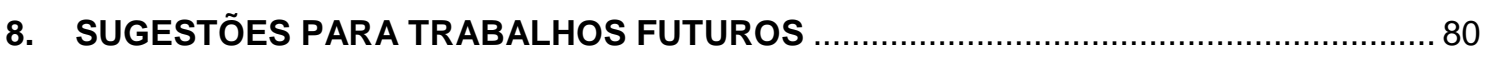

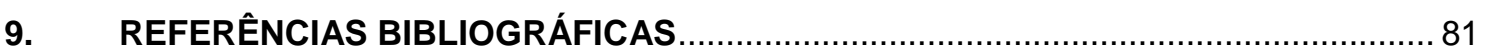

ANEXO 1 - MODELO DE CURVA ANALÍSTICA PARA QUANTIFICAÇÃO PROTEICA .........92

ANEXO 2 - MODELO DE FICHA APLICADA NO TESTE SENSORIAL ................................. 93

ANEXO 3 - MODELO DO TERMO DE CONSENTIMENTO PREENCHIDO PELOS PROVADORES 
ANEXO 4 - ESPECIFICAÇÕES DAS MATÉRIAS-PRIMAS (ESTEARINA DE PALMA E GOMA XANTANA) 


\section{INTRODUÇÃO}

Uma das grandes tendências atuais na área de alimentos é a busca por produtos naturais e saudáveis que possam contribuir para o bem-estar do consumidor. Este fato vem em contraposição à também crescente procura por produtos industrializados, por possuírem, entre outras características, maior conveniência (alta estabilidade, fácil preparo ou prontos para o consumo). Tal problemática vem se refletindo na prática acadêmica e industrial através dos grandes esforços em pesquisa e tecnologia em busca de inovações no sentido da preservação de nutrientes naturalmente presentes nos alimentos. Nos casos onde o processamento industrial requerido pode prejudicar nutricionalmente o alimento, a busca é pela adição de bioativos naturais que estejam devidamente protegidos de processos de degradação. Estes compostos podem vir até a substituir aditivos cuja ingestão é controlada e/ou substituir aqueles que vêm sendo banidos devidos aos efeitos nocivos por consumo prolongado.

Um grande desafio é descobrir um compromisso entre a proteção devida do composto ativo durante as etapas de industrialização e distribuição e sua biodisponibilidade no organismo humano após ingeridos.

Este é o caso específico dos carotenoides, cuja estabilidade depende, entre outros fatores, da sua exposição ao oxigênio, à luz, calor e variações de pH (CONN et al., 1991; EDGE et al., 1997). O grupo dos carotenoides é formado por diversos compostos, dentre os quais os mais importantes para a ingestão humana são aqueles que possuem atividade próvitamina $A$. Não menos importante é sua ação bioquímica como antioxidante. O betacaroteno, o carotenoide mais comumente encontrado e utilizado em alimentos, é um eficiente pro-vitamínico $A$ e tem ação antioxidante atuando na fase de propagação da oxidação lipídica, reagindo com os radicais peroxil e quando em quantidades suficientes, interrompendo a reação (EDGE et al., 1997). Em alimentos também é incorporado para conferir coloração amarelo-alaranjada aos produtos. Importante ressaltar sua comprovada ação de prevenção de doenças coronarianas, cardíacas e alguns tipos de câncer (PALACE et al., 1999; BERTRAM; VINE, 2005).

Sabe-se que a absorção de vitaminas lipossolúveis pelo organismo é aumentada quando ingeridas juntamente com compostos ricos em lipídios (MCCLEMENTS et al., 2009). Uma abordagem interessante é, portanto, encapsular o beta-caroteno em matrizes lipídicas, como os sistemas coloidais lipídicos de encapsulação como emulsões, lipossomas e as partículas lipídicas sólidas. As partículas lipídicas sólidas são estruturas que possuem um núcleo de lipídio sólido envolvido por uma monocamada de tensoativo, o que as torna 
estruturas hidrofóbicas, mas dispersíveis em meios aquosos. Podem ser produzidas em escala micrométrica ou nanométrica, misturando-se diferentes tipos de lipídios (ceras, gorduras, óleos), dando origem a uma vasta gama de microestruturas

O iogurte integral é um alimento rico em lipídios cujo consumo está relacionado com alimentação saudável e nutricionalmente balanceada. Este produto é desejado tanto pelas suas qualidades nutricionais, tais como aporte de cálcio, proteínas de alto valor nutricional e vitaminas lipossolúveis quanto pela manutenção e balanceamento da microbiota intestinal e atributos sensoriais. (ROBINSON, et al. 2006). O iogurte é um produto versátil que pode ser consumido puro ou com adição de frutas, mel, cereais e até como tempero e ingrediente em diversas preparações culinárias. Além disso, o mercado do iogurte no Brasil é promissor e encontra-se em crescimento. Dados do Ministério da Agricultura, Pecuária e Abastecimento (BRASIL, 2013) revelam que a demanda do iogurte cresceu 2,97\% ao ano entre 2008 e 2012.

Neste contexto, o objetivo principal deste trabalho de Mestrado foi a produção e a caracterização de micropartículas sólidas encapsulando beta-caroteno, estabilizadas com isolado proteico de soja bem como a aplicação de tais sistemas em iogurte. 


\section{REVISÃO BIBLIOGRÁFICA}

\subsection{MICRO E NANOENCAPSULAÇÃO DE BIOATIVOS ALIMENTÍCIOS}

As técnicas de microencapsulação vêm sendo aplicadas à produção de fármacos há mais de três décadas, e devido às suas vantagens, também tornaram-se alvos de interesse das indústrias química, veterinária, cosmética e de alimentos (GOUIN, 2004; DESAI E PARK, 2005; MADENE et al., 2006). A necessidade de proteção de substâncias contra degradação durante a produção e estocagem deriva da suscetibilidade de diversos bioativos frente a condições de temperatura, $\mathrm{pH}$, luz e ação de oxidantes, agindo isoladamente ou em conjunto (NEDOVIC; KALUSEVIC; MANOJLOVIC, 2011).

Existem diversas técnicas de encapsulação de compostos bioativos, cada qual adaptada às características dos compostos e suas aplicações. Quanto ao método de obtenção, as nano e/ou microcápsulas pode ser obtidas através de processos mecânicos ou físico-químicos (ZUIDAM; SHIMONI, 2010; DE VOS et al. 2010).

Os processos mecânicos mais aplicados a indústria de alimentos são o spray-drying e aglomeração, spray-chilling, leito fluidizado e extrusão/co-extrusão. Estes métodos são facilmente adaptáveis à escala industrial, e envolvem aplicação de cisalhamento e/ou temperaturas moderadas a altas e produzem partículas do tipo matricial e cápsulas com recobrimento, no caso das duas últimas técnicas mencionadas (ZUIDAM; SHIMONI, 2010).

O processo de secagem por spray-drying é uma das técnicas mais empregadas de encapsulação na área de alimentos, pois resulta em pós de boa qualidade, baixa atividade de água e fácil transporte e estocagem (TONON et al., 2008). Consiste, na transformação de um material fluido (solução, dispersão ou pasta) em partículas secas na forma de pó, através da aspersão de tal material fluido em um meio de secagem aquecido, geralmente o ar (RÉ, 1998; DESAI E PARK, 2005).

Por sua vez, a técnica de spray-cooling ou spray-chilling consiste na atomização de um lipídio fundido em uma câmara fria, na qual ocorre a solidificação do lipídio em finas partículas. A temperatura da câmara varia de acordo com o ponto de fusão dos lipídios empregados, sendo de 32 a $42^{\circ} \mathrm{C}$ para o spray-chilling e spray-cooling é mais elevada, entre 45 a $122^{\circ} \mathrm{C}$ (OKURO et al. 2013).

O método de encapsulação em leito fluidizado é utilizado para secagem seguida de recobrimento, em batelada ou sistema contínuo. As partículas ficam suspensas pela ação de vazão constante de ar, e são pulverizadas com material de recobrimento. Este material de recobrimento deve possuir características específicas de viscosidade que permitam seu bombeamento, estabilidade ao calor, e capacidade de formação de filme ao redor das partículas (DEWETTINCK; HUYGHEBAERT, 1999). 
No processo de extrusão e co-extrusão, primeiramente é injetada uma massa fundida a base de mono ou dissacarídeos e então pressionada por uma ou mais matrizes a temperaturas acima de $100^{\circ} \mathrm{C}$. Na sequência do processo à massa fundida soma-se 0 composto ativo a ser encapsulado. Após extrusão, as partículas entram em contato com um solvente a baixa temperatura, isopropanol ou nitrogênio líquido são os mais frequentemente utilizados, de modo que o material de recobrimento enrijeça. No caso particular da coextrusão, é utilizado equipamento dotado de sistema para extrusão de multifluidos concêntricos. As partículas obtidas variam em tamanho na faixa de 80 a $2.000 \mu \mathrm{m}$ (ZUIDAM; SHIMONI, 2010; DE VOS et al. 2010).

Entretanto, os métodos mais utilizados na indústria de alimentos possuem limitações na incorporação de bioativos hidrofóbicos. Além disso, existem limitações tecnológicas na incorporação de tais substâncias em formulações aquosas, situação na qual a molécula deve se dispersar. Para alcançar tal objetivo, as técnicas mais empregadas estão relacionadas com a produção de sistemas coloidais lipídicos, como as emulsões, as microemulsões, as micelas, os lipossomas e as partículas lipídicas sólidas (SILVA, 2013). Tais sistemas possuem duas grandes vantagens:

(i) Possibilitam a dispersão dos bioativos hidrofóbicos em formulações com grande quantidade de água;

(ii) A presença de lipídios pode melhorar significativamente a absorção de moléculas hidrofóbicas uma vez que a dissolução, a permeabilidade intestinal, a estimulação do transporte linfático e o tempo de residência gástrica podem ser aumentados/ estimulados, ou a redução da atividade dos transportadores intestinais de efluxo e a bomba de efluxo de P-glicoproteína, bem como o metabolismo baseado em enterócitos (DAHAN E HOFFMAN, 2008; JEONG et al., 2007). A bioacessibilidade de bioativos hidrofóbiocos pode ser aumentada devido à presença de lipídios na formulação do sistema encapsulante pois há aumento da solubilização do bioativo no meio intestinal através de alterações da composição e do caráter das estruturas coloidais existentes no meio - por exemplo, vesículas, micelas mistas e micelas (PORTER et al., 2007). 
Existem diferentes estruturas relacionadas com os sistemas lipídicos de encapsulação, conforme pode ser visto na Figura 1:
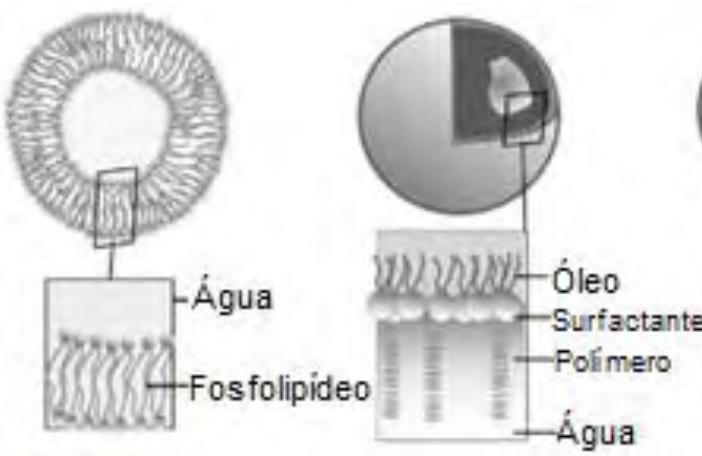

Lipossoma unilamelar
Cápsula e interface
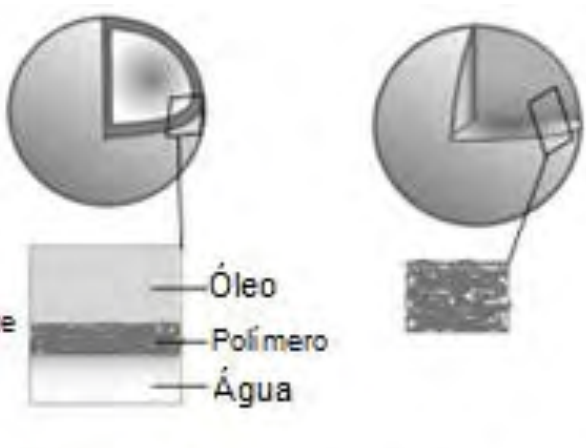

Cápsula com recobrimento
Partícula matricial

Figura 1. Exemplos de estrutura de sistemas encapsulantes lipídicos (adaptado de GONNET et al., 2010).

Segundo McClements e Li (2010), os sistemas lipídicos de encapsulação devem reunir características funcionais de teor e eficiência de encapsulação, eficiência e mecanismo de liberação, proteção à degradação química e biodisponibilidades específicas. Além disso, tais sistemas devem possuir características técnicas de aplicação, tais como segurança alimentar das matérias-primas utilizadas (uso de materiais GRAS - generally recognized as safe), compatibilidade com a matriz alimentícia e ao processo ao qual será destinado e viabilidade econômica.

Dentre os sistemas lipídicos de encapsulação mais estudados estão as emulsões, partículas lipídicas sólidas, lipossomas e micelas. A Figura 2 mostra esquematicamente exemplos de tais sistemas:

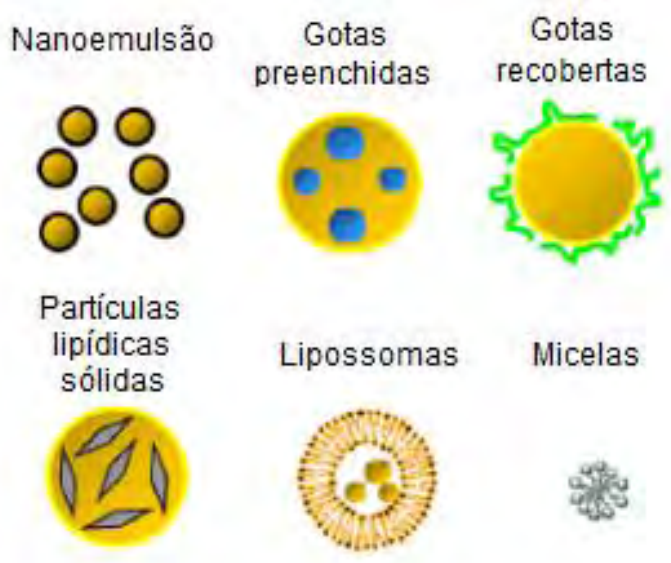

Figura 2. Exemplos de estruturas encontradas em sistemas lipídicos de encapsulação (adaptado de MCCLEMENTS E LI, 2010). 
De acordo com Mehnert e Mäder (2001), as partículas lipídicas sólidas são estruturas semelhantes às emulsões, mas o núcleo hidrofóbico é constituído de uma fase lipídica encontra-se total ou parcialmente solidificada. O diâmetro médio das partículas pode ser variado, podendo estar na faixa nanométrica (entre 20 e $200 \mathrm{~nm}$ ), submicrométrica (200 a $1000 \mathrm{~nm}$ ) ou micrométrica (1 a $5 \mu \mathrm{m}$ ) (SILVA et al., 2014). A Figura 3 mostra esquematicamente uma partícula lipídica sólida:

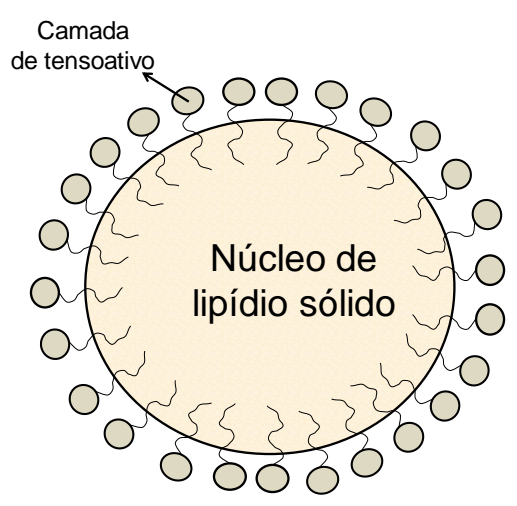

Figura 3. Esquema simplificado de uma partícula lipídica sólida.

As partículas lipídicas sólidas foram desenvolvidas pela indústria farmacêutica para serem aplicadas à administração de drogas vias intravenosa e parenteral, nas quais o diâmetro das partículas é fator altamente limitante (MÜLLER et al., 2000; JEONG; PARK; PARK, 2007). As vantagens de tal sistema de encapsulação são diversas, desde a baixa mobilidade do bioativo na matriz lipídica sólida, em comparação com matrizes líquidas, a capacidade de liberação controlada no sítio desejado, seu alto grau de biodegradabilidade, a total biocompatibilidade (MÜLLER et al., 2000; MEHNERT; MADER, 2001), bem como o fato de poderem ser produzidas com matérias-primas lipídicas comuns da indústria de alimentos.

Os modelos estruturais de dispersão de bioativos nas partículas lipídicas sólidas são: matriz homogênea, parede enriquecida e núcleo enriquecido, como esquematizado na Figura 4.

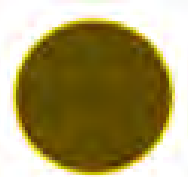

(a)

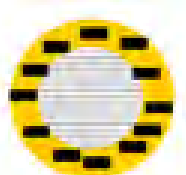

(b)

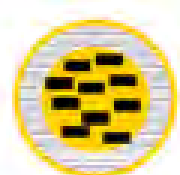

(c)

Figura 4. Modelos de incorporação de compostos ativos em partículas lipídicas sólidas: (a) matriz homogênea; (b) parede enriquecida e (c) núcleo enriquecido (fonte: SOUTO, 2006). 
Os benefícios da aplicação de partículas lipídicas sólidas vêm sendo intensamente investigado nos últimos anos. A exemplo desses trabalhos, Cornacchia e Roos (2011a) compararam emulsões encapsulando beta-caroteno produzidas com óleo de girassol ou gordura hidrogenada de palma estabilizadas com proteína de soro de leite e/ou caseinato de sódio. Os autores obtiveram resultados significativamente melhores de estabilidade de betacaroteno para os sistemas fabricados com o lipídio parcialmente sólido (gordura de palma) em relação ao óleo de girassol.

Por sua vez, Helgason et al. (2009) investigaram o efeito tensoativo de lecitinas de diferentes pontos de fusão e polissorbatos 60 e 80 na estabilidade física e química de suspensões de partículas contendo beta-caroteno encapsulado com tripalmitina (SLN) e triacilgliceróis de cadeia média (emulsão). Os autores verificaram melhor estabilidade do beta-caroteno nos sistemas de emulsão estabilizada com lecitinas de alto e médio ponto de fusão e para o sistema de SLN utilizando a lecitina de alto ponto de fusão, efeito atribuído ao impacto positivo das caudas polares da lecitina na cristalização do lipídio.

Também em estudos comparativos entre diferentes tipos de estrutura de nanopartículas lipídicas sólidas, Hentschel et al. (2008) observaram a aplicabilidade dos mesmos carregados com beta-caroteno para aplicação como ingrediente funcional em bebidas. O tamanho médio de partículas obtido nos ensaios com sistemas heterogêneos (sistemas compostos por mais de um tipo de lipídio) - aproximadamente $400 \mathrm{~nm}$ - indica possibilidade de aplicação em vasta gama de produtos sem ocorrência de fenômenos indesejáveis de cremeação ou sedimentação. As amostras de SLN (sistemas compostos por um lipídio purificado) mostraram estabilidade polimórfica ao longo de 7 meses de observação. As formulações testadas com a adição de alfa-tocoferol mostraram estabilidade no tamanho de partículas.

Relkin et al. (2008) estudaram o comportamento estrutural de nanoemulsões e nanopartículas lipídicas sólidas encapsulando alfa-tocoferol estabilizados com caseinato de sódio. Os autores notaram melhor preservação do alfa-tocoferol encapsulado nas nanoemulsões, desempenho associado ao fenômeno de exclusão observado durante a cristalização e solidificação da fase lipídica nas SLN.

Nesta mesma linha de pesquisa, Tikekar e Nitin (2012) estudaram o impacto da distribuição do material encapsulado na oxidação dos mesmos, comparando sistemas de nanopartículas lipídicas sólidas (lipídio puro) e carreadores lipídicos nanoestruturados (compostos de blendas lipídicas contendo lipídios líquidos e sólidos). Por meio de imagens obtidas via microscopia por fluorescência, foi observada diferença na distribuição do corante encapsulado entre os sistemas produzidos e a ocorrência do fenômeno de exclusão do corante para a fase aquosa, nos sistemas de nanopartículas lipídicas sólidas. Nos outros 
sistemas com pequenas quantidades de lipídio na fase líquida, foi observada redução significativa deste o fenômeno. A distribuição do corante encapsulado no interior das nanopartículas foi favorável nos sistemas contendo as blendas lipídicas. Foi sugerido pelos autores que pequenas imperfeições na superfície das nanopartículas (canais ou rachaduras) aumentam a velocidade de transporte de oxigênio para o interior das partículas causando impacto negativo na estabilidade do material.

Em estudo comparativo da eficiência entre sistemas micro e nanoparticulados, Gomes et al. (2013a) e Gomes et al. (2013b) avaliaram a produção de micro e nanopartículas lipídicas sólidas com fases oleosas contendo triestearina ou ácido esteárico e diferentes tipos de tensoativos para encapsulação do beta-caroteno. Os sistemas microparticulados contendo de $4 \%$ de ácido esteárico e o polisorbato 80 como tensoativo, na presença de alfa-tocoferol, mostraram-se os mais estáveis tanto em termos de estrutura como em relação à preservação do beta-caroteno, ao longo de período de observação de 7 meses.

Abordando estudos de sistemas lipídicos seguidos de ensaios de digestibilidade, Silva et al. (2014) avaliaram o comportamento de formulação de micropartículas lipídicas sólidas produzidas com ácido esteárico/triestearina e óleo de palmiste utilizando polisorbato 20, polisorbato 60 e span 80 como tensoativo, ambos na concentração de $4 \%$ em massa e espessante goma xantana. Os ensaios se mostraram muito estáveis ao longo do período observado, sendo que o melhor desempenho foi observado para as formulações de triestearina com goma xantana.

Finalmente, a Tabela 1 mostra outros exemplos de estudos sobre a produção e caracterização de micro e nanopartículas lipídicas sólidas com bioativos de interesse na área de alimentos: 
Tabela 1. Exemplos de estudos encontrados na literatura empregando micro e nanopartículas lipídicas sólidas para encapsulação de bioativos de interesse na área alimentícia.

\begin{tabular}{|c|c|c|c|}
\hline Bioativo & Fase lipídica & Tensoativo(s) & Referência \\
\hline $\begin{array}{l}\text { Óleo essencial } \\
\text { de Artemisia } \\
\text { arborescens } L .\end{array}$ & Compritol 888 & Pluronic F68 & Lai et al. (2006) \\
\hline Ômega-3 & Tripalmitina & Tween 20 & Awad et al. (2009) \\
\hline Quercetina & Gliceril monostearato & $\begin{array}{l}\text { Lecitina de soja, Tween } \\
\quad 80 \text { e PEG } 400\end{array}$ & Li et al. (2009) \\
\hline Quercetina & Tristearina & $\begin{array}{c}\text { PC soja } \\
\text { hidrogenada }\end{array}$ & $\begin{array}{l}\text { Scalia e Mezzena } \\
\text { (2009) }\end{array}$ \\
\hline $\begin{array}{c}\beta \text {-caroteno + } \\
\alpha \text {-tocoferol }\end{array}$ & Ferulato estearílico & Tween 20 & Trombino et al. (2009) \\
\hline$\beta$-caroteno & Tripalmitina & Tween 20 & Helgason et al. (2009) \\
\hline$\beta$-caroteno & $\begin{array}{l}\text { Ácido esteárico, } \\
\text { tristearina, trilaurina, } \\
\text { ácido láurico }\end{array}$ & $\begin{array}{l}\text { L-a-fosfatidilcolina e } \\
\text { dipalmitoil } \\
\text { fosfatidilcolina }\end{array}$ & $\begin{array}{l}\text { Triplett II e Rathman } \\
\text { (2009) }\end{array}$ \\
\hline Luteína & $\begin{array}{l}\text { Gliceril } \\
\text { palmitoestearato,ác. } \\
\text { palmítico } \\
\text { Triglicerídeos caprílicos e } \\
\text { cápricos, ácidos láurico, } \\
\text { mirístico e esteárico }\end{array}$ & Pluronic F68 & Liu e Wu (2010) \\
\hline $\begin{array}{l}\beta \text {-caroteno }+ \\
\text { tocois }\end{array}$ & $\begin{array}{l}\text { Glicerídeos de óleo de } \\
\text { palmiste hidrogenado }\end{array}$ & $\begin{array}{c}\text { Span } 40 \text { and Tween } \\
80\end{array}$ & Hung et al. (2011) \\
\hline$\alpha$-tocoferol & Óleo de palma & WPC & $\begin{array}{c}\text { Shukat e Relkin } \\
\text { (2011), Shukat et al. } \\
\text { (2012) }\end{array}$ \\
\hline$\beta$-caroteno & $\begin{array}{l}\text { Óleo de palmiste } \\
\text { hidrogenado }\end{array}$ & $\begin{array}{l}\text { WPI, } \\
\text { caseinato de sódio }\end{array}$ & $\begin{array}{l}\text { Cornacchia e Roos } \\
\text { (2011a), } \\
\text { Cornacchia e Roos } \\
(2011 b)\end{array}$ \\
\hline$\beta$-caroteno & Estearina de canola & $\begin{array}{l}\text { Tween 80, } \\
\text { Poloxamer } 188\end{array}$ & $\begin{array}{c}\text { Malaki-Nik et al. } \\
(2012)\end{array}$ \\
\hline$\beta$-caroteno & $\begin{array}{l}\text { n-hexadecil palmitato, } \\
\text { gliceril estearato, óleo de } \\
\text { semente de uva e } \\
\text { esqualeno }\end{array}$ & Tween 80, Tween 20 & Lacatusu et al. (2012) \\
\hline Catalase & Tripalmitina & Poloxamer 188 & Qi et al. (2012) \\
\hline Coenzima Q10 & Compritol 888 & $\begin{array}{c}\text { Poloxamer } 188 \text { e } \\
\text { Tween } 80\end{array}$ & Gokce et al. (2012b) \\
\hline Ergocalciferol & Tripalmitina & Tween 20 & $\begin{array}{l}\text { Patel e Martin- } \\
\text { González (2012) }\end{array}$ \\
\hline Nisina & Imwitor 900 & $\begin{array}{c}\text { Poloxamer } 188 \text { e } \\
\text { deoxicolato de sódio }\end{array}$ & $\begin{array}{c}\text { Prombutara et al. } \\
\text { (2012) }\end{array}$ \\
\hline Resveratrol & $\begin{array}{l}\text { Compritol } 888 \text { and Mygliol } \\
812\end{array}$ & $\begin{array}{c}\text { Poloxamer } 188 \text { e } \\
\text { Tween } 80\end{array}$ & Gokce et al. (2012a) \\
\hline Quercetina & Mygliol 812N & $\beta$-lactoglobulina & Pool et al. (2013) \\
\hline
\end{tabular}




\subsection{CAROTENOIDES}

Os carotenoides são pigmentos naturais sintetizados por vegetais e microorganismos. Existem aproximadamente 700 tipos de carotenoides na natureza, divididos por suas características estruturais em dois grupos: os carotenos hidrocarbonados e as xantofilas oxigenadas (DAMODARAM et al., 2010; DEMAN, 1999). A base estrutural dos carotenos são unidades de isopreno ligadas covalentemente na forma cabeça-cauda ou cauda-cauda, sendo que algumas estruturas podem ter grupos cíclicos terminais (caso do beta-caroteno) ou então apenas uma ou nenhuma ciclização (por exemplo, o licopeno). Os carotenoides com esqueleto carbônico mais curto são conhecidos como apocarotenais (a bixina é um exemplo). Dos carotenoides conhecidos, aproximadamente 40 tipos possuem atividade pró-vitamina A (OLLILAINEN et al., 1988), como o beta-caroteno, alfa-caroteno, gama-caroteno, alfa-criptoxantina e beta-criptoxantina, que contam em sua estrutura molecular com a presença de um anel beta-ionona não substituído, responsável pela ação biológica ora citada, conforme ilustrado na Figura 5 (DAMODARAM et al., 2010; DEMAN, 1999).

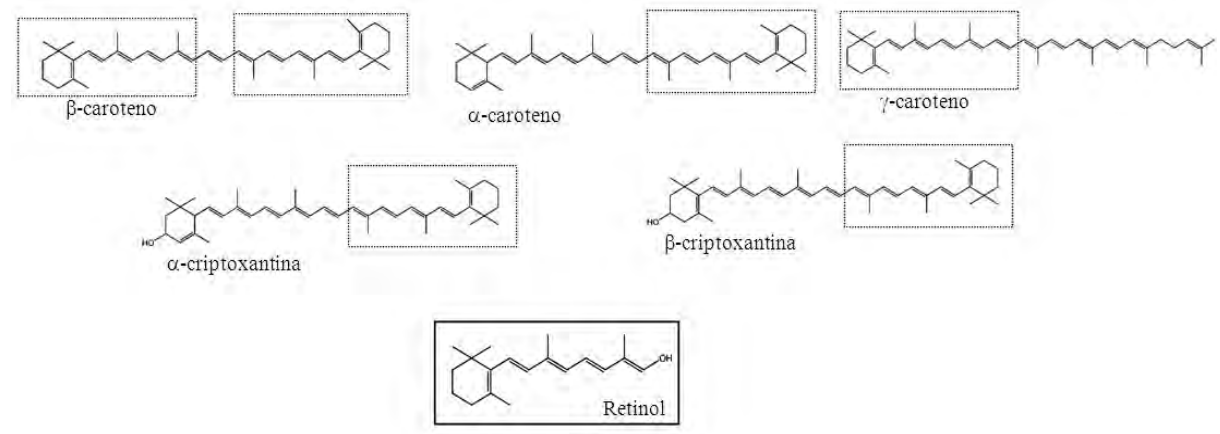

Figura 5. Estruturas moleculares de carotenoides pró-vitamínicos. (adaptado de Damodaram et al., 2010).

Dentre carotenoides com ação pró-vitamina A, o beta-caroteno é o que a possui em maior quantidade (DAMODARAM et al., 2010; DEMAN, 1999). Se expressarmos a vitamina A em retinol-equivalentes, sendo 1 retinol equivalente igual a $1 \mu \mathrm{g}$ de retinol, são necessários $6 \mu \mathrm{g}$ de beta-caroteno para se obter 1 retinol equivalente. Ao se utilizar outros carotenoides, são necessários $12 \mu \mathrm{g}$ (DEMAN, 1999).

Inúmeros estudos reportam que a ação antioxidante da vitamina A pode auxiliar na prevenção de diversas doenças. A ação antioxidante dos carotenoides deriva do fato de possuírem a cadeia de ligações conjugada, que é capaz de remover radicais livres do meio em que se encontram, através da oxidação das suas ligações duplas. Tal capacidade de se 
ligar aos radicais livres é responsável pela correlação entre os carotenoides e seu papel na prevenção de doenças (FRASER E BRAMLEY, 2004) cuja origem está relacionada com excesso de radicais livres no organismo (EDGE et al., 1997), ações sobre o sistema imunológico (HUGHES et al., 1997) e prevenção de doenças coronarianas e câncer (BERTRAM et al., 2005; PALACE et al., 1999).

No entanto, os carotenoides são moléculas extremamente susceptíveis à isomerização, o que pode alterar a solubilidade, hidrofobicidade e cristalinidade dos mesmos, entre outras características. Além disso, devido às ligações duplas, são moléculas muito susceptíveis à oxidação. O alto grau de hidrofobicidade da maioria dos carotenoides, com valores de log $\mathrm{P}$ de 14,76 para o beta-caroteno, 14,5 para o licopeno e 11,5 para a luteína (MCCLEMENTS, 2012), é dificultado, ou muitas vezes pode tornar impossível a adição destes compostos em formulações alimentícias de base aquosa. Desta forma, se faz necessário incorporar os carotenoides em uma matriz hidrofóbica que seja dispersível em água, como, por exemplo, nas partículas lipídicas sólidas.

\subsection{PROTEÍNAS DA SOJA}

Muitos são os motivos de pesquisa acerca da proteína de soja e suas propriedades e aplicações, em razão de propriedades nutricionais, funcionais e seu baixo custo. (BARAC, et al., 2004). Estudos atuais se concentram também na modificação destas proteínas a fim de

melhorar características como solubilidade, capacidade espumante, gelificante, e emulsificante, bem como a inativação de agentes anti-nutricionais (FOEGEDING et al., 2011). Os usos mais frequentes da proteína da soja são em suplementos proteicos, produtos cárneos (como substitutos), alimentos infantis, produtos à base de peixe e produtos de panificação (TAKEITI, 2002).

A proteína de soja é utilizada na indústria de alimentos sob as formas de farinha de soja, concentrado e isolado proteico de soja. Os concentrados e isolados proteicos de soja são obtidos a partir da eluição dos componentes solúveis da farinha de soja desengordurada, por meio de solvente ácido $(\mathrm{pH} 4,5)$, solução etanólica (70\%) ou água com agentes lixiviantes. Os isolados são obtidos a partir da farinha tratada em solução alcalina $(\mathrm{pH} 8,0)$ seguida de remoção do material insolúvel por centrifugação/filtração, precipitação da proteína em pH 4,5; neutralização e secagem (KINSELLA, 1979).

As proteínas de estocagem encontradas na soja são em sua grande maioria globulinas e representam $70 \%$ da proteína solúvel. As globulinas presentes na soja podem ser subdivididas em 4 classes de acordo com suas propriedades de sedimentação (BARAC 
et al., 2004). A fração 2S, denominada $\alpha$-conglicinina, a fração $7 S$ (dividida em $\beta$ conglicinina, $\mathrm{y}$-conglicinina e a globulina 7S básica), a fração 11S (glicinina) e a fração 15S. Juntas, as 7S e 11S compõem aproximadamente 70 a 90\% da totalidade da fração proteica da soja. $\beta$-conglinina e glicinina possuem diferenças estruturais, sendo peso molecular da primeira 150 a $180 \mathrm{KDa}$, e a segunda $340 \mathrm{KDa}$. Esta diferença reflete em suas propriedades funcionais, a exemplo da solubilidade, sendo a $11 \mathrm{~S}$ insolúvel a $\mathrm{pH} 6,4$ entre $2-5^{\circ} \mathrm{C}$ e a $7 \mathrm{~S}$ insolúvel a pH 4,8. Existe diferença marcante na sensibilidade térmica entre essas proteínas; o ponto de transição térmica da glicinina é $92^{\circ} \mathrm{C}$, enquanto para a $\beta$-conglicinina, $72^{\circ} \mathrm{C}$. Esta diferença pode ser explicada pela estrutura mais compacta e estável da glicinina (BARAC et al., 2004).

O recurso mais utilizado para modificações da proteína de soja é o tratamento térmico (KINSELLA, 1979; BARAC et al., 2004). A ação do calor reduz a atividade do inibidor de tripsina, elimina a lipoxigenase e compostos voláteis indesejáveis, aumentando a digestibilidade e a aceitação sensorial. $\mathrm{O}$ aquecimento acima de $70^{\circ} \mathrm{C}$ pode dissociar a estrutura quaternária das frações $7 \mathrm{~S}$ e $11 \mathrm{~S}$, desnatura suas subunidades e pode promover a formação de agregados via interações eletrostáticas, hidrofóbicas e dissulfídicas (BARAC et al., 2004; KINSELLA, 1979). Essa ação pode ser positiva quando se deseja aumentar a capacidade emulsificante de proteínas. O poder tensoativo de proteínas está relacionado com a queda da tensão interfacial entre as fases água/óleo, que por sua vez, está ligado à capacidade da proteína de migrar, adsorver, desdobrar e se rearranjar na interface (KINSELLA, 1979; SANTIAGO et al., 2008). 


\subsection{IOGURTE}

logurte, segundo a definição do Ministério da Agricultura, é o produto oriundo da fermentação controlada do leite com "cultivos protosimbióticos de Streptococcus salivarius subsp. thermophilus e Lactobacillus delbrueckii subsp. bulgaricus aos quais podem-se acompanhar, de forma complementar, outras bactérias ácido-lácticas que, por sua atividade contribuem para a determinação das características do produto final". Em relação à composição físico-química, deve-se respeitar os limites expressos na Tabela 2:

Tabela 2. Parâmetros físico-químicos do iogurte exigidos pela legislação (BRASIL, 2007).

\begin{tabular}{|c|c|c|c|c|c|}
\hline \multicolumn{4}{|c|}{ Matéria gorda láctea $(\mathrm{g} / \mathbf{1 0 0 g})\left(^{*}\right)$} & \multirow{2}{*}{$\begin{array}{c}\text { Acidez } \\
\text { (g de ácido } \\
\text { lático/100g) }\end{array}$} & \multirow{2}{*}{$\begin{array}{c}\text { Proteínas } \\
\text { lácteas } \\
(\mathrm{g} / 100 \mathrm{~g})\end{array}$} \\
\hline Com creme & Integral & $\begin{array}{c}\text { Parcialmente } \\
\text { desnatado }\end{array}$ & Desnatado & & \\
\hline Min. 6,0 & $3-5,9$ & $0,6-2,9$ & Máx. 0,5 & $0,5-1,50$ & Mín. 2,9 \\
\hline
\end{tabular}

Ainda de acordo com a legislação brasileira, é permitida a adição de beta-caroteno como corante na quantidade máxima de $50 \mathrm{mg} / \mathrm{kg}$.

O processo de fabricação do iogurte envolve as etapas de recepção do leite, seguida de filtração, pasteurização, fermentação, resfriamento e acondicionamento refrigerado. É importante frisar a importância do controle do tratamento térmico prévio a fermentação para padronizar a microbiota inicial do leite e assim garantir maior controle da fermentação e padronização do iogurte obtido (TAMIME; ROBINSON, 2004).

A fermentação é uma das etapas críticas do processo de fabricação do iogurte. As culturas de Streptococcus thermophilus e Lactobacillus bulgaricus apresentam comportamento simbiótico, o que resulta em velocidade de acidificação e formação de metabólitos acelerada. Logo após a inoculação, o microorganismo Streptococcus thermophilus é o mais ativo dada sua capacidade de crescimento em $\mathrm{pH}$ neutros. $\mathrm{O}$ ácido lático gerado abaixa o pH e como resultado da fermentação da lactose alguns subprodutos são produzidos (tais como formiato e $\mathrm{CO}_{2}$ ) tornando o ambiente propício para o crescimento do Lactobacillus bulgaricus. Este último, então, inicia sua fermentação e proteólise da caseína e proteínas do soro (em especial $\beta$-lactoglobulina e $\alpha$-lactalbumina), formando peptídeos e aminoácidos livres como metionina, triptofano, valina e ácido glutâmico. Neste ponto, dado o aumento da acidez do meio, inibe-se a ação do Streptococcus thermophilus, enquanto o Lactobacillus bulgaricus persiste por possuir maior resistência a meios ácidos do que o primeiro. Nesse momento da fermentação pode-se observar a formação do coágulo, 
que pode ser rompido durante a etapa de agitação, presente na fabricação dos iogurtes batidos (TAMIME; ROBINSON, 2004).

Um número expressivo de pesquisas científicas encontradas na atualidade versam sobre iogurtes adicionados de culturas probióticas (MEDEIROS, 2013; LOLLO et al., 2013; HEKMAT et al., 2006; LOURENS-HATTING et al., 2001). Outros estudos de relevância objetivam o redução do teor de gordura e manutenção das características sensoriais dos iogurtes (KRZEMINSKI et al., 2011).

Em relação a suplementação de iogurte com bioativos não-probióticos, pode-se citar o trabalho de Toniazzo et al.(2014), que pesquisaram a produção de lipossomas multilamelares encapsulando beta-caroteno estabilizadas com gomas xantana e guar. As formulações se mostraram estáveis também quando aplicadas no iogurte, sem presença de grumos nem separação de fases, e foram aprovadas por uma parcela significativa de painelistas submetidos a teste afetivo de aceitação sensorial do iogurte incorporado com beta-caroteno encapsulado.

Outro estudo interessante sobre a adição de bioativo não-probiótico em iogurte é o estudo realizado por Gutierres et al. (2012). Os autores testaram o efeito de iogurte suplementado com curcumina em ratos diabéticos, e concluíram que o bioativo, acima de certas doses, exibiu atividade anti-diabética, aumentando significativamente os marcadores acessados no estudo.

\subsection{ESTEARINA DE PALMA}

A estearina de palma é um produto obtido da Elaeis guineensis, conhecida no Brasil por "palmeira do dendê" ou palmeira de óleo africana. Essa espécie, originária da África Ocidental, vem sendo explorada há quase 5000 anos como fonte de alimento; no entanto, somente em 1917, na Malásia, ela foi pela primeira vez plantada em larga escala com objetivos comerciais (BIODIESELBR, 2014; AGROPALMA, 2014).

O processamento da estearina de palma inicia-se com o cozimento dos frutos a aproximadamente $135^{\circ} \mathrm{C}$ sob pressão de 2 a $3 \mathrm{~kg} / \mathrm{cm}^{2}$, durante 1 hora. Então os frutos são encaminhados a um debulhador que separa os cachos dos frutos. Os frutos são, então, prensados mecanicamente em prensa contínua, onde ocorre a saída do óleo do mesocarpo. Este óleo cru é transportado a um desaerador, onde são separadas as partículas pesadas para ser então clarificado e purificado para remoção de umidade e demais impurezas. 0 óleo bruto é bombeado para o tanque de decantação, onde ocorre a separação do óleo e da borra. O óleo é transferido para tanque de armazenagem, enquanto que a borra é centrifugada e transferida para um decantador secundário. $O$ óleo bruto é filtrado em filtro 
prensa e segue para o processo de fracionamento, em tanque com controle do resfriamento e baixa agitação. Ao final, o óleo resfriado filtrado, resultando nas frações estearina e oleína. (BIODIESELBR, 2014; AGROPALMA, 2014).

A Tabela 3 ilustra o perfil de ácidos graxos obtidos de amostras de óleo de palma, oleína de palma e estearina de palma.

Tabela 3. Perfil de ácidos graxos de amostras de óleo, estearina e oleína de palma (adaptado de Kalustian, 1985).

\begin{tabular}{lcccc}
\hline \multicolumn{1}{c}{ Ácido graxo } & $\begin{array}{c}\text { Óleo de } \\
\text { Palma }\end{array}$ & $\begin{array}{c}\text { Estearina de } \\
\text { palma }\end{array}$ & $\begin{array}{c}\text { Oleína de } \\
\text { palma }\end{array}$ \\
\hline Láurico & $\mathrm{C}_{12}$ & 0,2 & $0,1-0,6$ & $0,1-1,1$ \\
Mirístico & $\mathrm{C}_{14}$ & 1,1 & $1,1-1,9$ & $0,9-1,4$ \\
Palmítico & $\mathrm{C}_{16}$ & 44 & $47,2-73,8$ & $37,9-41,7$ \\
Esteárico & $\mathrm{C}_{18: 0}$ & 4,5 & $4,4-5,6$ & $4,4-4,8$ \\
Oleico & $\mathrm{C}_{18: 1}$ & 39,2 & $15,6-37$ & $40,7-43,9$ \\
Linoleico & $\mathrm{C}_{18: 2}$ & 10,1 & $3,2-9,8$ & $10,4-13,4$ \\
Outros & - & 0,8 & $0,2-1,2$ & $0,4-1,5$ \\
\hline
\end{tabular}

A estearina de palma vem sendo explorada para uso em sistemas lipídicos encapsulantes pelas indústrias farmacêutica, cosmética e alimentícia, dadas suas características tecnológicas, versatilidade de aplicação, composição, baixo custo, entre outras (YAP et al., 1989). Dentre os trabalhos publicados recentemente, destaca-se a pesquisa realizada por Zheng et al. (2013), que avaliaram a influência de gordura hidrogenada de girassol, gordura hidrogenada de canola e misturas de óleo e estearina de palma em diferentes proporções na formação e propriedade de partículas lipídicas sólidas encapsulando ácido linoleico conjugado. Eles concluíram que as características das matrizes lipídicas influenciaram fortemente no tamanho e na distribuição de diâmetro das partículas produzidas. Observou-se ainda que a presença de lipídio líquido no núcleo diminuiu o diâmetro de partícula e os pontos de fusão verificados nos termogramas obtidos por calorimetria diferencial de varredura, e ainda alargaram os picos de fusão. Além disso, a presença de óleo líquido no núcleo das partículas produziram formações cristalinas imperfeitas, o que poderia promover a liberação controlada e absorção do material encapsulado. 
Com base nas informações colocadas na presente revisão bibliográfica, é possível identificar a importância do beta-caroteno em relação aos benefícios para a saúde humana, bem como sua sensibilidade à degradação em condições comuns de processamento de alimentos. Há, portanto, a necessidade de se desenvolver sistemas capazes de protegê-lo e possibilitar a sua incorporação em produtos alimentícios (de base aquosa), e possibilitar o aumento de sua bioacessibilidade. Como foi colocado, uma das maneiras de se conseguir tal intento é através da microencapsulação, principalmente se forem utilizados para tais processos materiais que auxiliem na absorção dos bioativos no intestino, tais como os lipídios. No entanto, a encapsulação com essas aplicações na indústria alimentícia começaram a ser desenvolvidas há pouco tempo, necessitando de mais estudos nesta área. Aplicações de partículas lipídicas sólidas em alimentos ainda são raros na literatura, e, portanto, este trabalho de Mestrado tem o objetivo de contribuir no sentido de possibilitar a aplicação de beta-caroteno microencapsulado em partículas lipídicas sólidas em um produto lácteo, o iogurte. 


\section{OBJETIVOS}

O objetivo principal deste trabalho de Mestrado foi a produção e a caracterização de micropartículas sólidas encapsulando beta-caroteno, estabilizadas com isolado proteico de soja bem como a aplicação de tais sistemas em iogurte batido sabor cenoura, laranja e mel. Para alcançar este objetivo principal, os seguintes objetivos específicos foram atingidos:

- Estabelecimento de protocolos de produção das micropartículas lipídicas sólidas encapsulando beta-caroteno com isolado proteico de soja;

- Caracterização dos sistemas microencapsulantes resultantes através de análises de calorimetria diferencial de varredura, difração de raios- $X$, tamanho de partículas e potenciall zeta e concentração de beta-caroteno encapsulado;

- Caracterização das dispersões de isolado proteico de soja através de análises físicoquímicas por meio de determinação do potencial zeta, tensão interfacial, hidrofobicidade superficial, eletroforese em gel de poliacrilamida, calorimetria diferencial de varredura;

- Aplicação dos sistemas microencapsulantes em iogurte e avaliação das características físico-químicas por meio de composiçao centesimal, viscosidade, colorimetria instrumental, aceitação sensorial dos atributos cor, sabor, textura e avaliação global. 


\section{MATERIAIS}

\subsection{CARACTERIZAÇÃO DO ISOLADO PROTEICO DE SOJA E PRODUÇÃO DAS MICROPARTÍCULAS LIPÍDICAS SÓLIDAS}

Para a produção das micropartículas lipídicas foi utilizada estearina de palma doada pela Agropalma (Belém, Brasil), proteína isolada de soja Supro® 780 , (Solae ${ }^{\mathrm{TM}}$ Company, DuPont, Paulínia, Brasil), goma xantana Grindsted® Xanthan 80, (doada pela Danisco, Cotia, Brasil), benzoato de sódio (Synth, Diadema, Brasil), $\beta$-caroteno (Sigma-Aldrich, SaintLouis, EUA) e $\alpha$-tocoferol (Sigma-Aldrich, Saint-Louis, EUA).

No ensaio de estabilidade físico-química das micropartículas lipídicas em diferentes condições de stress, foram utilizados cloreto de sódio (Synth, Diadema, Brasil) e sacarose (Synth, Diadema, Brasil).

Foram utilizados, para a quantificação de $\beta$-caroteno, etanol (Merck, São Paulo, Brasil), metanol (Merck, São Paulo, Brasil), hidróxido de potássio (Synth, Diadema, Brasil), hexano (Merck, São Paulo, Brasil), di-terc-butil metil fenol (BHT) (Synth, Diadema, Brasil) e sulfato de sódio anidro (Synth, Diadema, Brasil).

Para a quantificação de proteína pelo método de Lowry foi utilizado reagente Folin Ciocalteau 1N (Merck, São Paulo, Brasil), soroalbumina bovina (Inlab), carbonato de sódio anidro (Synth, Diadema, Brasil), hidróxido de sódio (Synth, Diadema, Brasil), sulfato de cobre (Synth, Diadema, Brasil), tartarato de sódio e potássio (Synth, Diadema, Brasil).

$\mathrm{Na}$ análise de hidrofobicidade superficial foi utilizado sonda ácido 8-anilino-1naftalenosulfônico (ANS) (SigmaAldrich, China), fostato de sódio monobásico anidro (Synth, Diadema, Brasil) e fosfato de potássio monobásico anidro (Synth, Diadema, Brasil).

Para o ensaio de eletroforese foram utilizados $\beta$-mercaptoetanol (Merck, Darmstadt, Alemanha), dodecil sulfato de sódio (L5750, Sigma-Aldrich, Saint Louis, EUA), acrilamida (Bio-Rad, Hercules, EUA), N.N'-metileno-bis acrilamida (Merck, São Paulo, Brasil), glicerol (Merck, São Paulo, Brasil), persulfato de amônia (Sigma-Aldrich, Saint Louis, EUA ), tetrametilenodiamina - TEMED (Sigma-Aldrich, Saint Louis, EUA) e ácido clorídrico 37\% (Merck, São Paulo, Brasil).

Os materiais para a determinação do perfil de aminoácidos totais por cromatografia líquida de alta eficiência, foram: ácido clorídrico a 37\% (Merck, Darmstadt, Alemanha); fenol a $99-100 \%$ (Synth, Diadema São Paulo, Brasil); acetato de sódio trihidratado a 99,9\% -100\% (Merck, Darmstadt, Alemanha); metanol pureza 99,7\%-100\% - grau HPLC (Synth, Diadema São Paulo, Brasil); trietilamina pureza 99\%-100\% (Merck, Darmstadt, Alemanha); ácido 
acético glacial a 99\%-100\% (Synth, Diadema, São Paulo, Brasil); acetonitrila a 99,7\%-100\%Grau HPLC (Synth, Diadema, São Paulo, Brasil); fenilisotiocianato (PITC - PIERCE - Part. № 26922 - CAS), a 99,5-100\% (Merck, Darmstadt, Alemanha); padrões para aminoácidos acídicos e neutros (Part. $\mathrm{N}^{\circ} \mathrm{A} 6407$ - 2,5 $\mu$ mols em $\mathrm{HCl} 0,1 \mathrm{M}$ ); e amino acid standard physiological - aminoácidos básicos (Part. $\mathrm{N}^{\circ} \mathrm{A} 6282$ - 2,5 $\mu$ mols em $\mathrm{HCl} 0,1 \mathrm{M}$ ), (SigmaAldrich, Saint Louis, EUA); padrão Part. $N^{\circ} 20088$ - amino acid standard H - 2,5 $\mu$ mols em $\mathrm{HCl}$ 0,1M - PIERCE, Thermo Fisher Scientific Inc. (Waltham, MA, EUA); acido alfaaminobutírico (AAAB). Como padrão interno foram empregados aminoácidos totais a 99100\% e metionina sulfona (padrão interno de aminoácidos livres) a 99-100\% (Sigma-Aldrich, Saint Louis, USA).

\subsection{PRODUÇÃO E CARACTERIZAÇÃO DE IOGURTE ADICIONADO COM BETA- CAROTENO ENCAPSULADO EM MICROPARTÍCULAS LIPÍDICAS SÓLIDAS}

Para a produção de iogurte foi utilizado leite bovino integral pasteurizado de produção própria da Prefeitura do Campus da USP de Pirassununga, fermento lácteo contendo Streptococcus thermophillus e Lactobacillus bulgaricus (YC-X11 Freeze-Dried 50U, CHR. Hansen, Horshom, Dinamarca), açúcar cristal Colombo (Ariranha, São Paulo, Brasil), cenoura desidratada (doada pela empresa Liotécnica, Embu das Artes, Brasil) e aromas de mel e laranja (doados pela Symrise, Sorocaba, Brasil).

Na determinação de teor de gordura foi utilizado ácido sulfúrico para análise de leite (Synth, Diadema, Brasil) e álcool isoamílico (Synth, Diadema, Brasil).

A determinação da acidez titulável foi realizada utilizando-se solução padronizada de hidróxido de sódio (Synth, Diadema, Brasil) na concentração de 0,10 M e solução de fenolftaleína 1\% (m/v) (Synth, Diadema, Brasil). 


\section{MÉTODOS}

\subsection{COMPOSIÇÃO CENTESIMAL DO ISOLADO PROTEICO DE SOJA}

\subsubsection{DETERMINAÇÃO DA PORCENTAGEM DE PROTEÍNA}

A análise do conteúdo proteico foi realizada pelo método de Kjeldahl, teste clássico de determinação de teor proteico em alimentos, que inclui etapas de digestão, destilação e titulação (AOAC, 1997). Para o processo de digestão da proteína foram utilizados $0,10 \mathrm{~g}$ da amostra de IPS. A tal massa de amostra adicionou-se $1,5 \mathrm{~g}$ de catalisador $\left(96 \% \mathrm{~K}_{2} \mathrm{SO}_{4}, 4 \%\right.$ $\mathrm{CuSO}_{4} .5 \mathrm{H}_{2} \mathrm{O}$ ) e $3 \mathrm{ml}$ de $\mathrm{H}_{2} \mathrm{SO}_{4}$ concentrado. Um tubo "branco" foi preparado apenas com catalisador $\left(96 \% \mathrm{~K}_{2} \mathrm{SO}_{4}, 4 \% \mathrm{CuSO}_{4} .5 \mathrm{H}_{2} \mathrm{O}\right)$ e $\mathrm{H}_{2} \mathrm{SO}_{4}$ concentrado. Os tubos foram colocados no digestor a $100^{\circ} \mathrm{C}$ por 1 hora e então a temperatura foi elevada gradativamente até atingir $400^{\circ} \mathrm{C}$. O processo foi acompanhado até que uma solução límpida e translúcida, sem pontos pretos, foi obtida. Para a etapa de destilação de nitrogênio, foram utilizadas soluções de $\mathrm{HCl}$ $0,20 \mathrm{M}, \mathrm{NaOH} 40 \%$ e ácido bórico $2 \%$. A solução de $\mathrm{HCl} 0,20 \mathrm{M}$ foi padronizada com $\mathrm{Na}_{2} \mathrm{CO}_{3}$ utilizando alaranjado de metila como indicador. Foi adicionado ácido bórico aos tubos, e as amostras foram neutralizadas com $\mathrm{NaOH} 40 \%$. Posteriormente, as amostras foram destiladas (destilador Marconi, modelo MA 036). Os destilados então foram titulados com $\mathrm{HCl}$ 2M. Para o "branco", foi descontado o volume das amostras.

\subsubsection{DETERMINAÇÃO DO TEOR LIPÍDICO}

A determinação do conteúdo lipídico do IPS foi determinado pelo método de Bligh and Dyer (1959). Foram utilizados $2,5 \mathrm{~g}$ de IPS e adicionados $10 \mathrm{ml}$ de clorofórmio, $20 \mathrm{ml}$ de metanol e $8 \mathrm{ml}$ de água destilada em erlenmeyers que foram submetidos a agitação por 30 minutos. Foram adicionados a seguir $10 \mathrm{ml}$ de clorofórmio, $25 \mathrm{ml}$ de solução de $\mathrm{Na}_{2} \mathrm{SO}_{4}$ $1,5 \%$, sendo então os frascos agitados por mais 20 minutos. Após separação de fases, as camadas inferiores existentes nos erlenmeyers foram recolhidas e colocadas em tubos de ensaio, onde foram adicionados $\mathrm{Na}_{2} \mathrm{SO}_{4}$ anidro. Os tubos foram agitados por 2 minutos no agitador tipo vórtex e, em seguida, o conteúdo foi filtrado em filtro Whatman 40 . Béqueres previamente secos foram pesados e neles foram adicionados $8 \mathrm{ml}$ dos filtrados. Em seguida, foram conduzidos para secagem em estufa a $85^{\circ} \mathrm{C}$ por 30 minutos e a $95^{\circ} \mathrm{C}$ por 20 horas. 


\subsubsection{DETERMINAÇÃO DO TEOR DE UMIDADE}

A porcentagem de água presente na amostra foi determinada por método gravimétrico por secagem em estufa a $105^{\circ} \mathrm{C}$ (INSTITUTO ADOLFO LUTZ, 2008). Aproximadamente 5 gramas de IPS foram pesados em placas previamente limpas e secas. As amostras foram deixadas em estufa a $105^{\circ} \mathrm{C}$ por 24 horas, resfriadas em dessecador com sílica e posteriormente pesadas.

\subsubsection{DETERMINAÇÃO DO TEOR DE CINZAS}

Foi utilizado método gravimétrico após tratamento e secagem em mufla (INSTITUTO ADOLFO LUTZ, 2008). Aproximadamente $1,5 \mathrm{~g}$ de IPS foram pesados em balança anaOÇÇlítica em cadinhos calcinados previamente. Em seguida, as amostras foram incineradas com o uso de um bico de Bunsen e colocadas em mufla a temperatura de $550^{\circ} \mathrm{C}$, e lá deixadas até que as cinzas mostrarem coloração clara, quando foram resfriados em dessecador e pesados.

Todos os ensaios de composição centesimal foram realizados em triplicata.

\subsection{CARACTERIZAÇÃO E PRODUÇÃO DAS DISPERSÕES DE ISOLADO PROTEICO DE SOJA}

\subsubsection{DETERMINAÇÃO DO POTENCIAL ZETA}

As amostras de IPS foram dispersas em água e submetidas a diferentes condições de $\mathrm{pH}$ com adição de solução de $\mathrm{NaOH}$ ou $5 \mathrm{M} \mathrm{HCl} 5 \mathrm{M}$. Foram determinadas as cargas superficiais por meio da leitura dos valores de potencial zeta das diferentes soluções. $O$ potencial zeta das soluções foi obtido das soluções diluídas em $\mathrm{KCl} 0,1 \mathrm{M}$ e posterior leitura de suas mobilidades eletroforéticas pela técnica de espalhamento de luz, com ângulo de espalhamento de $45^{\circ}$. Os dados apresentados são ajustados pelo modelo de HelmholtzSmoluchowski. As leituras e tratamentos dos dados foram realizados pelo software incluso no equipamento ZetaPlus (Brookhaven Instruments Company, Holtsville, EUA).

\subsubsection{ELETROFORESE EM GEL DE POLIACRILMIDA (SDS-PAGE)}

Os ensaios de eletroforese SDS-PAGE foram realizados no Laboratório de Fontes Proteicas do Departamento de Alimentos e Nutrição da FEA/UNICAMP, em equipamento BioRad modelo Mini Protean II (Hercules, Califórnia, USA). Foi utilizado protocolo para 
formulação dos géis e tampões proposto por Laemmli (1970). Utilizou-se placas de vidro com espaçamento de $0,75 \mathrm{~mm}$, e geis de separação e empacotamento (este último com camada de $0,5 \mathrm{~cm}$ de altura) compostos de $30 \%$ T e 2,67\% C. A composição detalhada dos géis pode ser visualizada na Tabela 4. As amostras de IPS, tanto original quanto após 0 tratamento alcalino-térmico, foram diluídas a uma concentração de proteína de 0,4\%.

Tabela 4. Composições dos geis de separação, empacotamento e tampão redutor de amostra.

\begin{tabular}{lccc}
\hline & $\begin{array}{c}\text { Gel de } \\
\text { separação } \\
(\mathbf{1 2 \%})\end{array}$ & $\begin{array}{c}\text { Gel de } \\
\text { empacotamento } \\
(\mathbf{4 \% )}\end{array}$ & $\begin{array}{c}\text { Tampão } \\
\text { redutor de } \\
\text { amostra }\end{array}$ \\
\hline Acrilamida:Bis-acrilamida $(\mathrm{mL})$ & 4,0 & 1,3 & 0 \\
Água destilada $(\mathrm{mL})$ & 3,4 & 6,1 & 3,4 \\
1,5M Tris-HCl pH 8,8 $(\mathrm{mL})$ & 2,5 & 2,5 & 0 \\
0,5M Tris-HCl pH 6,8 $(\mathrm{mL})$ & 0 & 0 & 1,0 \\
SDS 10\% $(\mathrm{mL})$ & 0,1 & 0,1 & 1,6 \\
Glicerol $(\mathrm{mL})$ & 0 & 0 & 1,6 \\
TEMED $(\mu \mathrm{L})$ & 10 & 10 & 0 \\
Persulfato de amônia 10\% $(\mathrm{p}: \mathrm{v})(\mu \mathrm{L})$ & 50 & 50 & 0 \\
ß-mercaptoetanol $(\mathrm{mL})$ & 0 & 0 & 0,4 \\
\hline
\end{tabular}

\subsubsection{ESPECTROSCOPIA DE INFRAVERMELHO COM TRANSFORMADA DE} FOURIER (FT-IR)

As amostras de IPS foram preparadas conforme descrito no item 5.2.7 e a seguir liofilizadas em liofilizador Terroni modelo LC 1500 (São Carlos, São Paulo, Brasil). O IPS na forma original foi analisado sem preparo prévio. As análises de espectroscopia de infravermelho foram realizadas em equipamento Spectrum One (Perkin Elmer, USA) usando-se 16 varreduras por amostra, no intervalo de números de onda entre 4000 e 400 $\mathrm{cm}^{-1}$, no Laboratório de Tecnologia de Alimentos do Departamento de Engenharia de Alimentos da FZEA / USP. Os resultados foram tratados pelo programa existente no próprio equipamento.

\subsubsection{DETERMINAÇÃO DA HIDROFOBICIDADE SUPERFICIAL}

O protocolo para determinação da hidrofobicidade superficial do isolado proteico de soja foi adaptado de HAYAKAWA (1985) e DINIZ (2007). As amostras de IPS tratadas e não tratadas foram dispersas em tampão fosfato $0,1 \mathrm{M}$, a pH 7,0, na concentração de $2,5 \mathrm{mg} / \mathrm{mL}$ e homogeneizadas em agitação magnética a temperatura ambiente por $1 \mathrm{~h}$ e centrifugadas a $4000 \mathrm{~g}$ por 15 minutos a $4^{\circ} \mathrm{C}$ (centrífuga Sorwall Legend MACH 1.6R, Thermo Scientific, Waltham, MA, EUA). Realizou-se uma varredura para escolha do comprimento de onda de 
emissão máxima das amostras dos sobrenadantes. As leituras das fluorescências das amostras e branco, com adição de ANS até a saturação, foram realizadas com excitação de $363 \mathrm{~nm}$ e emissão de $475 \mathrm{~nm}$ em espectrofluorímetro Perkin Elmer modelo LS55, Waltham Massachusetts, EUA. Os teores proteicos dos sobrenadantes foram verificados pelo método de Lowry adaptado por Peterson (1979). A curva analítica para determinação da concentração proteica foi obtida utilizando-se soroalbumina bovina.

\subsubsection{DETERMINAÇÃO DO PERFIL DE AMINOÁCIDOS TOTAIS}

O preparo da amostra consiste em hidrólise com ácido clorídrico $6 \mathrm{~N}$, durante 24 horas. Os aminoácidos liberados na hidrólise ácida são reagidos com fenilisotilcianato e separados por HPLC em fase reversa para posterior detecção por espectrometria U.V. a 254 $\mathrm{nm}$. A quantificação é feita com auxílio do ácido a-aminobutírico como padrão interno para aminoácidos totais e de metionina sulfona para aminoácidos livres. Utilizou-se cromatógrafo tipo HPLC da Thermo Fisher Scientific Inc. (Waltham MA, EUA), com os módulos degassificador Spectra System (Thermo Separation Products - Waltham MA, EUA), módulo de bomba quaternária Spectra System P4000 (Thermo Separation Products - Waltham MA, EUA), válvula de injeção Rheodyne, Forno Thermasphere TS-130 HPLC (Phenomenex Torrance, CA, EUA.), modulo de detecção UV Spectra System UV 2000 (Thermo Separation Products - Waltham MA, EUA). Foi aplicada metodologia modificada da proposta por White et al. (1986) para aminoácidos totais, com coluna LUNA C18 100A 5u 250x4,6mm 00G-4252-EQ. Para as determinações de aminoácidos livres utilizou-se coluna Pico-Tag Column, 60Å, 4 um, 3.9 mm X 300 mm, 1/pkg (WAT010950). O ensaio foi realizado no Laboratório de Fontes Proteicas (DEPAN - FEA - UNICAMP).

\subsubsection{DETERMINAÇÃO DA TENSÃO INTERFACIAL ENTRE DISPERSÃO DE ISOLADO PROTEICO DE SOJA E ESTEARINA DE PALMA}

Para realização das análises de tensão interfacial foi utilizado o tensiômetro de força (Attension KSV Intruments modelo Sigma 702), com anel de Du Nouy de Platina-Irídio, com raio de $9,545 \mathrm{~mm}$ e raio do filamento de 0,185 $\mathrm{mm}$. Mediu-se a tensão interfacial em sistemas bifásicos compostos de dispersões de isolado proteico de soja 1\%, em diferentes $\mathrm{pHs}$, e estearina de palma fundida. O ensaio foi conduzido à temperatura constante de $85^{\circ} \mathrm{C}$. 


\subsubsection{PRODUÇÃO DAS DISPERSÕES DE ISOLADO PROTEICO DE SOJA}

A dispersão do isolado proteico de soja em água foi realizada por meio de solubilização do isolado proteico em pó, em diferentes concentrações e condições de pH, conforme descrito na Tabela 5. Para variação do $\mathrm{pH}$ foram utilizadas soluções de $\mathrm{NaOH}$ e $\mathrm{HCl}$, ambas em concentração de 5M. O protocolo de dispersão pode ser visualizado na Tabela 6.

Tabela 5. Parâmetros utilizados para dispersão de isolado proteico de soja em água.

\begin{tabular}{lcc}
\hline \multicolumn{1}{c}{ Formulação } & Concentração de IPS em água $(\mathbf{m} / \mathbf{v})$ & $\mathbf{p H}$ \\
\hline IPS 0,25 & 0,25 & 12 \\
IPS 1,25 & 1,25 & 12 \\
IPS 1,00 pH 3 & 1,0 & 3 \\
IPS 1,00 pH 5 & 1,0 & 5 \\
IPS 1,00 pH 7 & 1,0 & 7 \\
IPS 1,00 pH 9 & 1,0 & 9 \\
IPS 1,00 pH 12 & 1,0 & 12 \\
IPS 1,50 & 1,5 & 12 \\
IPS 2,00 & 2,0 & 12 \\
IPS 2,50 & 2,5 & 12 \\
\hline
\end{tabular}

Dispersão do IPS original em água deionizada

Agitação magnética por 1 hora (temperatura ambiente)

Ajuste dos pHs

Tratamento térmico em banho-maria $\left(85^{\circ} \mathrm{C}\right.$ por 30 minutos)

\section{Resfriamento e armazenamento a $10^{\circ} \mathrm{C}$}

Figura 6. Diagrama de fluxo do protocolo utilizado para dispersão do isolado proteico de soja em água. 


\subsection{CARACTERIZAÇÃO FÍSICO-QUÍMICA DA ESTEARINA DE PALMA}

\subsubsection{DETERMINAÇÃO DA DENSIDADE}

O ensaio de densidade foi realizado em picnômetro de $100 \mathrm{~mL}$. A estearina de palma foi liquefeita em banho-maria e as pesagens foram realizadas a aproximadamente $85^{\circ} \mathrm{C}$. $\mathrm{O}$ experimento foi realizado em triplicata, no Laboratório de Processos de Separações, Departamento de Engenharia de Alimentos / FZEA

\subsubsection{CALORIMETRIA DIFERENCIAL DE VARREDURA (DSC)}

O ensaio de calorimetria diferencial de varredura foi realizado em equipamento TA5000 (TA Instruments, New Castle, EUA), varredura no intervalo de 0 a $100^{\circ} \mathrm{C}$, usando rampa de $10^{\circ} \mathrm{C} / \mathrm{min}$, disco de teflon e cadinho de alumínio. Cada ensaio foi realizado com alíquota de $10 \mathrm{mg}$ de amostra. $\mathrm{O}$ aquecimento ocorreu em atmosfera inerte $\left(45 \mathrm{~mL} / \mathrm{min} \mathrm{N}_{2}\right)$. Os resultados das entalpias e temperaturas de transição de fases foram dadas pelo software Universal Analysis V.7, fornecido pelo fabricante do equipamento. O equipamento foi calibrado com a substância química índio como padrão. O ensaio foi realizado no Laboratório de Tecnologia de Alimentos (LTA) do Departamento de Engenharia de Alimentos do ZEA-FZEA-USP.

\subsubsection{DIFRATOMETRIA DE RAIOS-X (DRX)}

Para o ensaio de difratometria de raios- $x$, a amostra de estearina de palma foi previamente tratada em banho-maria a $95^{\circ} \mathrm{C}$ por 1 hora, com objetivo de retirar sua memória térmica e a seguir resfriada até a temperatura ambiente. Os parâmetros de operação utilizados foram $2 \theta$ de $0^{\circ}$ até $40^{\circ}$, passo de $0,02^{\circ}$ e velocidade de $10^{\circ}$ /minuto.

O ensaio foi realizado em equipamento Rigaku, modelo Miniflex 600 (Osaka, Japão), com tubo de ânodo de cobre, no Laboratório de Materiais e Modelagem Dinâmica do Departamento de Engenharia de Biossistemas da FZEA/USP. 


\subsection{PRODUÇÃO E CARACTERIZAÇÃO DAS MICROPARTÍCULAS LIPÍDICAS SÓLIDAS (MLS)}

\subsubsection{DETERMINAÇÃO DAS DISTRIBUIÇÕES DE TAMANHO DE PARTÍCULA}

As micropartículas lipídicas produzidas foram monitoradas em relação a distribuição e diâmetro médio de partículas, pela técnica de espalhamento de luz dinâmico (Dynamic Light Scattering - DLS utilizando-se o equipamento ZetaPlus (Brookhaven Instruments Company, Holtsville, NY, EUA), com um laser de He-Ne de 627 nm, ângulo de incidência de $90^{\circ}$, na temperatura de $25^{\circ} \mathrm{C}$. Antes da análise as amostras foram diluídas com água deionizada (Millipore) para evitar o fenômeno do espalhamento múltiplo de luz. As análises dos dados foram realizadas pelo software incluído no sistema (90Plus).

\subsubsection{QUANTIFICAÇÃO DO BETA-CAROTENO ENCAPSULADO}

A quantificação do beta-caroteno encapsulado foi realizada por extração por hexano seguida de leitura da absorbância em espectrofotômetro. Foram adicionados 1,5 mL de etanol a $2 \mathrm{~mL}$ de amostras de partículas diluídas 50 vezes, com a finalidade de desestabilizar a dispersão, e $1 \mathrm{ml}$ de metanol contendo hidróxido de potássio, para promover a saponificação. Após agitação em vórtex por 10 segundos, o sistema foi deixado sob aquecimento $\left(45^{\circ} \mathrm{C}\right)$ por 30 minutos, com o intuito de aumentar a taxa de reação. Decorrido este tempo, foram adicionados $2 \mathrm{ml}$ de hexano contendo BHT, e o sistema foi agitado por 30 segundos no vórtex. Esta extração foi repetida três vezes. A obtenção da fase orgânica se deu após 10 minutos, e foi realizada a leitura da fase hexânica a $450 \mathrm{~nm}$. Antes da leitura espectrofotométrica, a camada orgânica foi removida e sulfato de sódio anidro foi adicionado, para absorção de possíveis resíduos de água. Este protocolo foi uma adaptação do protocolo original descrito por Cornacchia e Roos (2011).

\subsubsection{CALORIMETRIA DIFERENCIAL DE VARREDURA (DSC)}

$O$ ensaio de calorimetria diferencial de varredura foi realizado em equipamento TA5000 (TA Instruments, New Castle, EUA), varredura no intervalo de 0 a $100^{\circ} \mathrm{C}$, usando rampa de $10^{\circ} \mathrm{C} / \mathrm{min}$, disco de teflon e cadinho de alumínio. Cada ensaio foi realizado com alíquota de $10 \mathrm{mg}$ de amostra. $\mathrm{O}$ aquecimento ocorreu em atmosfera inerte $\left(45 \mathrm{~mL} / \mathrm{min} \mathrm{N}_{2}\right)$. Os resultados das entalpias e temperaturas de transição de fases foram fornecidas pelo software Universal Analysis V.7, fornecido pelo fabricante do equipamento. O equipamento 
foi calibrado com a substância química índio como padrão. O ensaio foi realizado no Laboratório de Tecnologia de Alimentos (LTA) do Departamento de Engenharia de Alimentos (ZEA/FZEA/USP).

\subsubsection{PRODUÇÃO DAS MICROPARTÍCULAS LIPÍDICAS}

Para a produção das micropartículas lipídicas foi utilizada dispersão de IPS previamente produzidas e estocadas a $10^{\circ} \mathrm{C}$. A estearina de palma foi utilizada como fase oleosa, tendo sido primeiramente retirada sua memória térmica através de aquecimento em banho-maria a $95^{\circ} \mathrm{C}$ por $30 \mathrm{~min}$. Adicionou-se $\beta$-caroteno e $\alpha$-tocoferol à fase oleosa sendo então a dispersão de IPS aquecida a $85^{\circ} \mathrm{C}$ e adicionada à fase oleosa sob ultra-agitação (T25, IKA, Alemanha). Imediatamente após a ultra-agitação ao sistema adicionou-se goma xantana e benzoato de sódio, segundo formulação descrita na Tabela 6 . Em seguida os sistemas foram resfriados até temperatura ambiente sob agitação magnética, período durante o qual ocorreu cristalização do núcleo lipídico das micropartículas. O protocolo descrito neste item pode ser observado de forma esquemática na Figura 7.

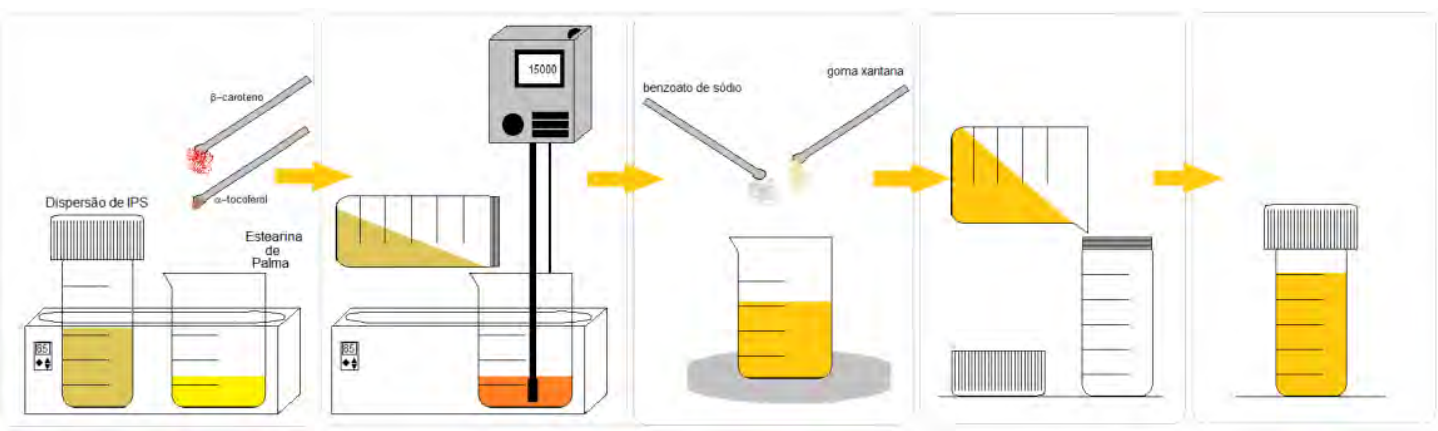

Figura 7. Representação esquemática do protocolo experimental utilizado para produção das micropartículas lipídicas.

Tabela 6. Formulações utilizadas para produção das micropartículas lipídicas.

\begin{tabular}{lccc}
\hline & Formulação A & Formulação B & Formulação C \\
\hline Dispersão de IPS 1\% & $150 \mathrm{~mL}$ & $150 \mathrm{~mL}$ & $150 \mathrm{~mL}$ \\
Estearina de palma & $5 \%$ & $5 \%$ & $5 \%$ \\
Beta-caroteno & $0,25 \%$ & $0,25 \%$ & $0,25 \%$ \\
Alfa-tocoferol & 0 & $0,125 \%$ & $0,25 \%$ \\
Goma xantana & $0,15 \%$ & $0,15 \%$ & $0,15 \%$ \\
Benzoato de sódio & $0,02 \%$ & $0,02 \%$ & $0,02 \%$ \\
\hline
\end{tabular}

Porcentagens descritas em base mássica $(\mathrm{m} / \mathrm{m})$. 


\subsection{PRODUÇÃO E CARACTERIZAÇÃO DE IOGURTE ADICIONADO DE BETA- CAROTENO MICROENCAPSULADO}

\subsubsection{PRODUÇÃO DO IOGURTE}

Os iogurtes foram produzidos na Seção de Laticínios da Prefeitura do Campus da USP de Pirassununga, de acordo com o fluxograma de produção apresentado na Figura 8. Os ingredientes e aditivos utilizados para a produção do iogurte e para a produção do iogurte com adição das partículas lipídicas encapsulando beta-caroteno estão listados nas Tabelas 7 e 8, respectivamente.

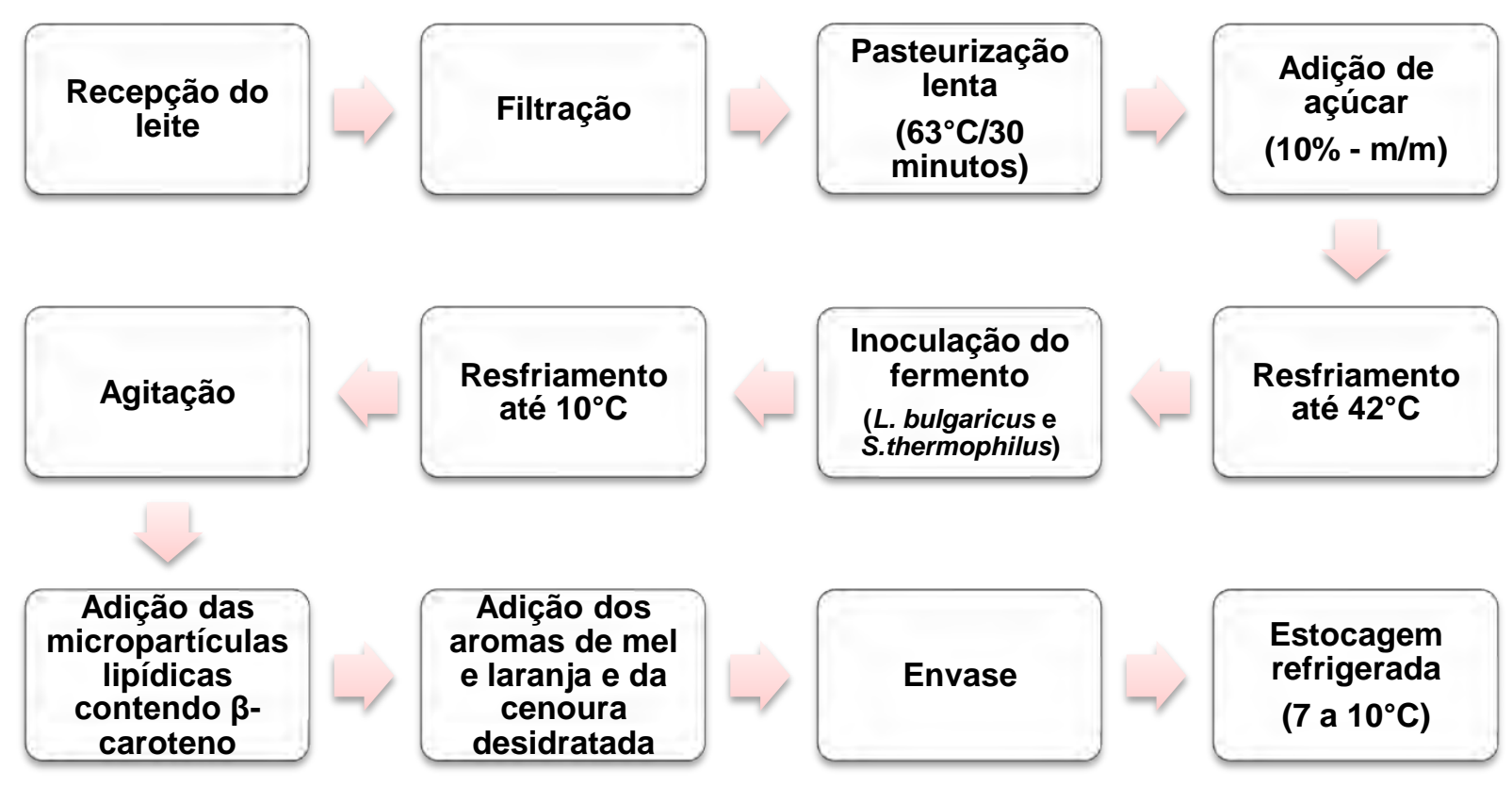

Figura 8. Fluxograma de produção do iogurte adicionado de micropartículas lipídicas encapsulando beta-caroteno.

Tabela 7. Formulação do iogurte branco.

\begin{tabular}{lc}
\hline \multicolumn{1}{c}{ Ingrediente } & Iogurte Branco \\
\hline Leite & $40 \mathrm{~L}$ \\
Açúcar & $4 \mathrm{Kg}$ \\
Fermento & $10 \mathrm{~g}$ \\
\hline
\end{tabular}


Tabela 8. Formulação dos iogurtes com adição de partículas lipídicas sólidas encapsulando betacaroteno produzidos.

\begin{tabular}{ccccc}
\hline Ingrediente & logurte 1 & logurte 2 & logurte 3 & "Branco" \\
\hline logurte Branco & $10 \mathrm{~L}$ & $10 \mathrm{~L}$ & $10 \mathrm{~L}$ & $10 \mathrm{~L}$ \\
Partículas - form. A & $500 \mathrm{~mL}$ & $500 \mathrm{~mL}$ & $500 \mathrm{~mL}$ & 0 \\
Partículas - form. B & $500 \mathrm{~mL}$ & $500 \mathrm{~mL}$ & $500 \mathrm{~mL}$ & 0 \\
Partículas - form. C & $500 \mathrm{~mL}$ & $500 \mathrm{~mL}$ & $500 \mathrm{~mL}$ & 0 \\
Aroma de mel & $0,05 \%$ & $0,05 \%$ & $0,05 \%$ & 0 \\
Aroma de laranja & $0,015 \%$ & $0,015 \%$ & $0,015 \%$ & 0 \\
Cenoura desidratada & $0,2 \%$ & $0,2 \%$ & $0,2 \%$ & 0 \\
\hline
\end{tabular}

Todas as porcentagens descritas em base mássica $(\mathrm{m} / \mathrm{m})$.

\subsubsection{CARACTERIZAÇÃO FÍSICO-QUÍMICA E MONITORAMENTO DA ESTABILIDADE DOS IOGURTES}

Os iogurtes produzidos neste trabalho de Mestrado foram analisados em relação ao teor de gordura, proteína, acidez titulável, pH, densidade. O teor de gordura do iogurte foi analisado pelo Método de Gerber. O iogurte foi diluído em água destilada na razão 1:10 para facilitar a pipetagem e o teste transcorreu em butirômetro para leite. $O$ teor proteico foi analisado pelo método de micro-Kjeldahl, pH, acidez titulável e densidade foram analisados conforme descrito em Adolfo Lutz (2008). As leituras foram feitas em triplicatas para todas as amostras e ensaios.

\subsubsection{AVALIAÇÃO SENSORIAL DOS IOGURTES}

Foram conduzidas sessões de avaliações sensoriais de aceitação dos iogurtes produzidos, com escala hedônica de nove pontos para os parâmetros cor, sabor textura e aceitação global. Recrutou-se aproximadamente 65 provadores consumidores de iogurte dentre alunos e funcionários da USP, campus de Pirassununga. As amostras de iogurte foram mantidas sob refrigeração entre $7-10^{\circ} \mathrm{C}$, sendo que sua aceitação sensorial foi monitorada em três tempos de armazenagem: 0,15 e 25 dias. Aos provadores foi solicitado assinalar, em uma escala hedônica de 9 pontos, com valores de 1 a 9 , o quanto gostaram ou desgostaram do produto em relação a quatro parâmetros: cor, textura, sabor e aceitação global. O modelo de ficha utilizada para preenchimento dos provadores se encontra no anexo I. As amostras foram apresentadas de forma codificada em números contendo 3 algarismos escolhidos de tabela estatística de ordens aleatórias dos dígitos 1 a 9 arranjados 
em grupos de 3 colunas (MEILGAARD et al., 1991), sendo 3 diferente códigos para a mesma amostra. A tabela de códigos pode ser visualizada no Anexo 1. As amostras foram apresentadas em ordem apresentada na tabela do Anexo 1. O ensaio ocorreu com a prévia autorização do Comitê de Ética da FZEA/USP, de acordo com normas para Estudos com Humanos da Plataforma Brasil. Os Termos de Consentimento Livre e Esclarecido foram assinados por cada um dos provadores em todas as sessões realizadas. Um modelo do Termo de Consentimento pode ser visualizado no Anexo 2. Os testes foram conduzidos no Laboratório de Análise Sensorial do Departamento de Engenharia de Alimentos / FZEA USP.

\subsubsection{COLORIMETRIA INSTRUMENTAL}

A determinação dos parâmetros colorimétricos instrumentais foi realizada em MiniScan XEPlus da Hunter Lab, (Reston, Virginia, EUA) com iluminante D65 e observador a $10^{\circ}$. Os resultados foram obtidos com o auxílio do programa Universal Software V4.10. Todas as leituras foram realizadas em triplicata.

\subsubsection{ANÁLISES REOLÓGICAS}

As análises reológicas dos iogurtes foram realizadas em reômetro rotacional de tensão controlada AR 2000 Rheometer (TA Instruments, New Castle, EUA). A geometria utilizada foi de placas paralelas de $2^{\circ}$. Todas as amostras foram analisadas à temperatura de $10^{\circ} \mathrm{C}$, com período de relaxamento das amostras antes do início de cada ensaio de 2 minutos. Os testes estacionários determinaram a tensão de cisalhamento a uma determinada taxa de cisalhamento variando de 0,01 a $100 \mathrm{~s}^{-1}$. Através das curvas de escoamento foi possível determinar a viscosidade das amostras e a tensão de escoamento, ou seja, a tensão mínima necessária para iniciar o escoamento da amostra. Os dados obtidos foram ajustados ao modelo Herschel-Bulkley através da Equação 1:

$$
\tau-\tau_{0}=k \dot{\gamma}^{n} \quad \text { (Equação 1) }
$$

onde, $\mathrm{k}=$ índice de consistência $\left(P a . s^{n}\right)$

$\mathrm{n}=$ índice de comportamento (adimensional)

$\tau=$ tensão de cisalhamento $(\mathrm{Pa})$

$\tau_{0}=$ tensão de cisalhamento inicial $(\mathrm{Pa})$

$\dot{\gamma}=$ taxa de deformação $\left(\mathrm{s}^{-1}\right)$ 
Os ensaios foram realizados em duplicata, no Laboratório de Tecnologia de Alimentos (FZEA-USP).

\subsection{ANÁLISES ESTATÍSTICAS}

Os tratamentos estatísticos dos resultados dos ensaios realizados foram feito com analise de variância e teste de diferença de médias por Tukey, com auxílio do programa SAS versão 9.3. 


\section{RESULTADOS E DISCUSSÃO}

\subsection{CARACTERIZAÇÃO DO ISOLADO PROTEICO DE SOJA}

\subsubsection{COMPOSIÇÃO CENTESIMAL DO ISOLADO PROTEICO DE SOJA}

Os ensaios de composição centesimal do isolado proteico de soja são mostrados na Tabela 9.

Tabela 9. Composição centesimal do isolado proteico de soja empregado neste trabalho de Mestrado.

Constituinte

\begin{tabular}{lc}
\hline Umidade $(\%)$ & $5,00 \pm 0,3$ \\
Lipídeos $(\mathrm{g} / 100 \mathrm{~g})$ & $1,6 \pm 0,3$ \\
Proteínas $(\mathrm{g} / 100 \mathrm{~g})$ & $89,0 \pm 2,7$ \\
Cinzas $(\mathrm{g} / 100 \mathrm{~g})$ & $2,2 \pm 0,30$ \\
Fibras $(\mathrm{g} / 100 \mathrm{~g})^{1}$ & 2,2 \\
\hline
\end{tabular}

'Informações do fornecedor (The SOLAE Company).

Da análise centesimal observa-se que o teor de proteínas é próximo a $90 \%$, característico de um isolado proteico de soja. Todos os demais parâmetros estão de acordo com o esperado para uma amostra de isolado proteico de soja.

\subsubsection{DETERMINAÇÃO DO POTENCIAL ZETA}

As amostras dos isolados proteicos de soja após serem submetidas ao tratamento alcalino-térmico tiveram seus $\mathrm{pH}$ ajustados para 3,5, 7, 9 e 12, a fim de avaliação dos valores de potencial zeta das mesmas. Os resultados obtidos para as medidas de potencial zeta podem ser observados na Figura 9. Nos ensaios cujo isolado proteico de soja foi tratado em soluções ácidas (IPS pH3 e IPS pH7), ocorreu indução de cargas superficiais resultando em valores positivos de potencial zeta, alcançando valores da ordem de $+25 \mathrm{mV}$. No entanto, e de acordo com o esperado, as amostras que foram submetidas aos pHs neutro e básicos resultaram em valores de potencial zeta negativos, devido à presença de grupo $\mathrm{OH}^{-}$ligados à estrutura proteica. Os valores obtidos para estes últimos ensaios foram 
$-29,1 \mathrm{mV} ;-51,9 \mathrm{mV}$ e $-37,8 \mathrm{mV}$ para os ensaios da proteína nos $\mathrm{pH} 7,9$ e 12, respectivamente.

Estes valores de potencial zeta são satisfatórios a fim de garantir estabilidade de partículas garantindo a repulsão eletrostática entre elas, uma vez que o valor típico da literatura que caracteriza um coloide estável é $\pm 30 \mathrm{mV}$ (McCLEMENTS, 2005).

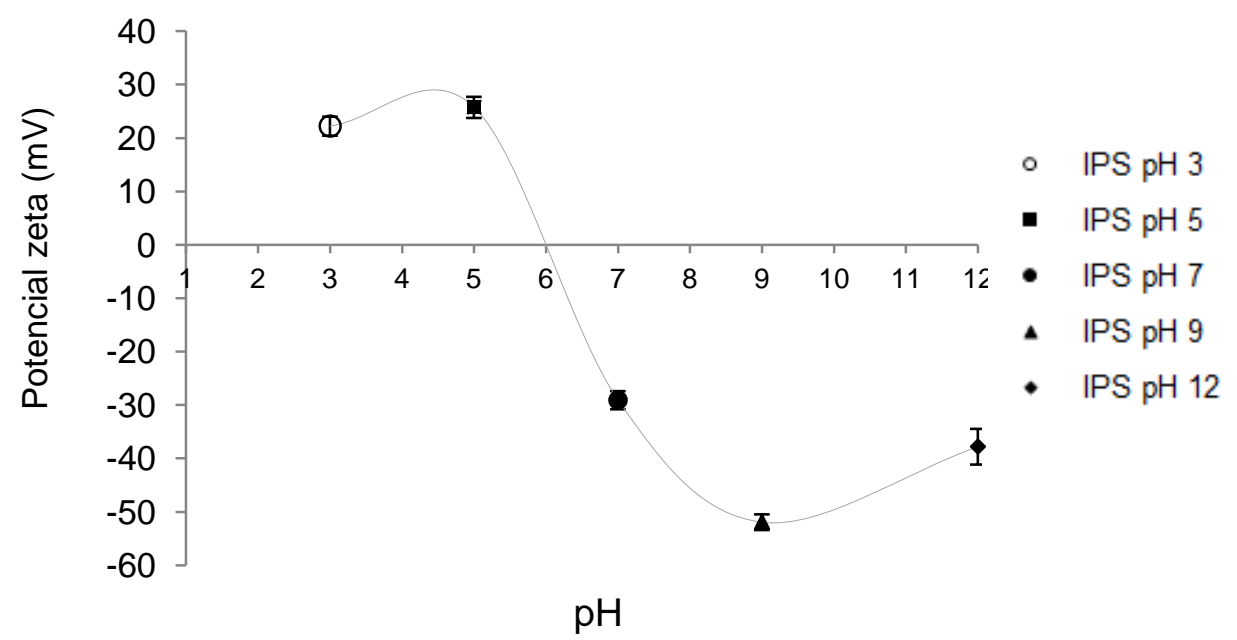

Figura 9. Valores de potencial zeta para amostras de dispersões de isolado proteico de soja após tratamento alcalino-térmico.

Pelos resultados obtidos também é importante ressaltar que o ponto isoelétrico do IPS tratado se localizou no $\mathrm{pH} 6$, o que foi confirmado também visualmente por meio da observação de separação de fase da dispersão no pH 5. 


\subsubsection{ELETROFORESE EM GEL DE POLIACRILAMIDA (SDS-PAGE)}

A Figura 10 mostra os perfis eletroforéticos das amostras de IPS original e após o tratamento alcalino-térmico:

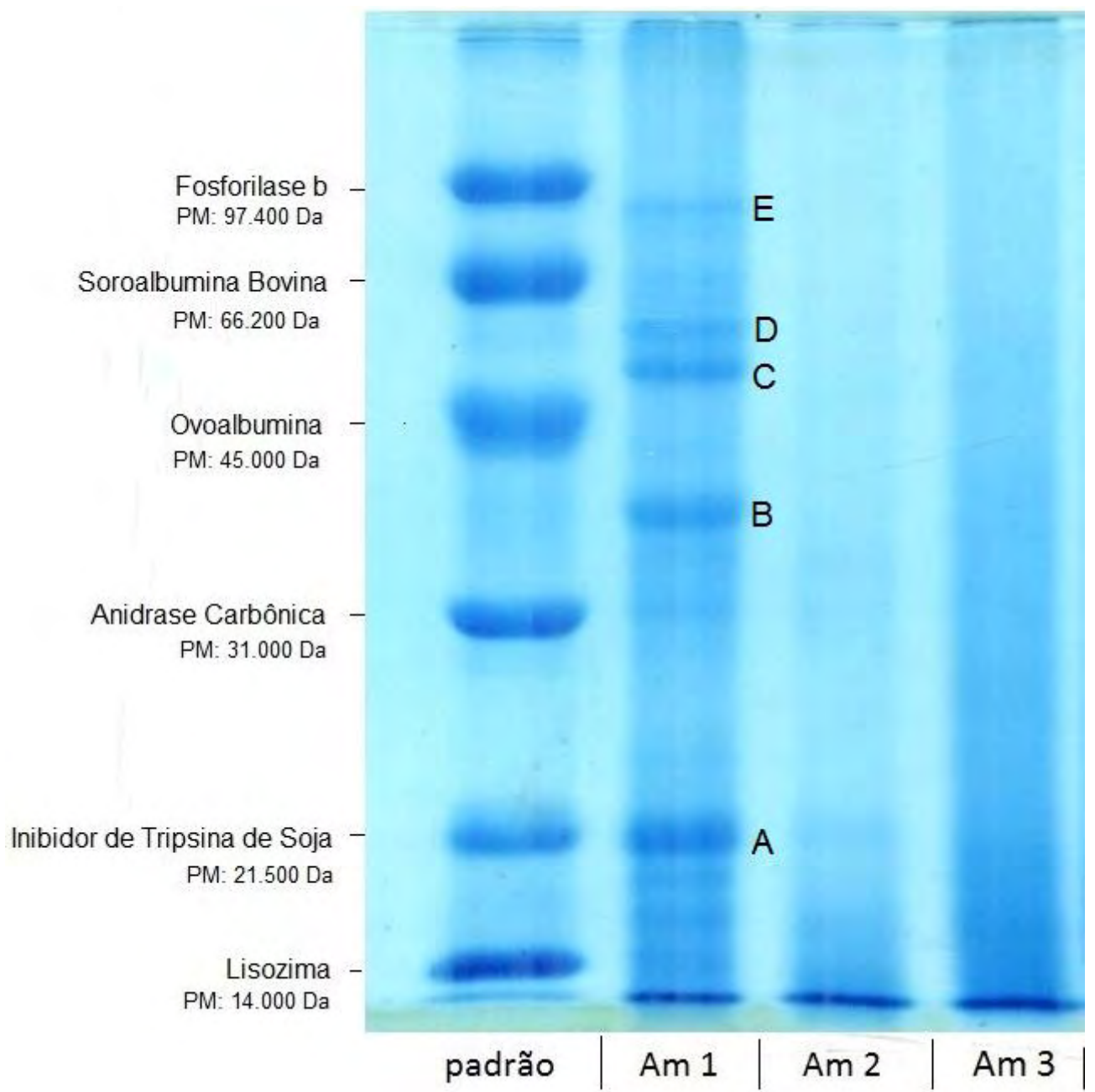

\section{LEGENDA:}

Am1 : Isolado proteico de soja original

Am2 : Isolado proteico de soja após agitação magnética em água a temperatura ambiente

Am3 : Isolado proteico de soja após tratamento alcalino térmico $(\mathrm{pH} 12)$

Figura 10. Eletroforese em gel de poliacrilamida na presença de SDS de amostras de isolado proteico de soja original e após tratamento alcalino-térmico.

$\mathrm{Na}$ análise da Figura 10, pode-se verificar que o isolado proteico de soja original (Am 1) apresentou 5 bandas, sendo uma com massa molecular de $21,5 \mathrm{kDa}(\mathrm{A})$, uma banda entre entre de 31 e $45 \mathrm{kDa}(\mathrm{B})$, duas bandas na região compreendida entre o padrões de 45 e $66,2 \mathrm{kDa}(\mathrm{C}$ e D) e uma banda menos intensa na região próxima a $80 \mathrm{kDa}(\mathrm{E})$. De acordo 
com Barac et al. (2004) as sub-unidades da glicinina - globulina 11S (360 kDa) são duas, um polipetídeo ácido (38 kDa) e outro básico (20 kDa) ligados por pontes dissulfídicas e dispostas na forma de dois hexágonos superpostos. A $\beta$-conglicinina - globulina 7S (150$180 \mathrm{kDa})$ possui 3 sub-unidades, $\alpha^{\prime}(72 \mathrm{kDa}), \alpha(68 \mathrm{kDa})$ e $\beta(52 \mathrm{kDa})$. Pode-se concluir que as bandas A, B, C, D e E na amostra 1 (AM1) encontradas referem-se, respectivamente, ao polipeptídio básico da glicinina, ao polipetídeo ácido da glicinina, a sub-unidade $\beta$ da betaconglicinina, a sub-unidade $\alpha$ da beta-conglicinina e a sub-unidade $\alpha$ ' da beta-conglicinina.

Paras as amostras do isolado proteico após o tratamento alcalino-termico, (Am 2 e Am 3) não foram observadas bandas específicas e definidas nas condições de ensaio empregadas. Tal fato é indicador da ocorrência de hidrólise das frações proteicas durante o processo de solubilização do IPS. Como as condições empregadas foram drásticas $(\mathrm{pH} 12$ a $85^{\circ} \mathrm{C}$ por 30 minutos), é muito possível que tal fato tenha ocorrido. Tal resultado está de acordo com o verificado por Sorgentini et al. (1995), que observaram desnaturação total da globulina $7 \mathrm{~S}$ e parcial da globulina 11S, em isolado proteico de soja a 5 e $15 \%$ em água $(\mathrm{m} / \mathrm{m})$ submetido a $80^{\circ} \mathrm{C}$ durante 30 minutos.

\subsubsection{ESPECTROSCOPIA DE INFRAVERMELHO COM TRANSFORMADA DE FOURIER (FT-IR)}

A Figura 11 mostra os espectros na região do infravermelho obtidos para o IPS original e o após tratamento alcalino-térmico: 


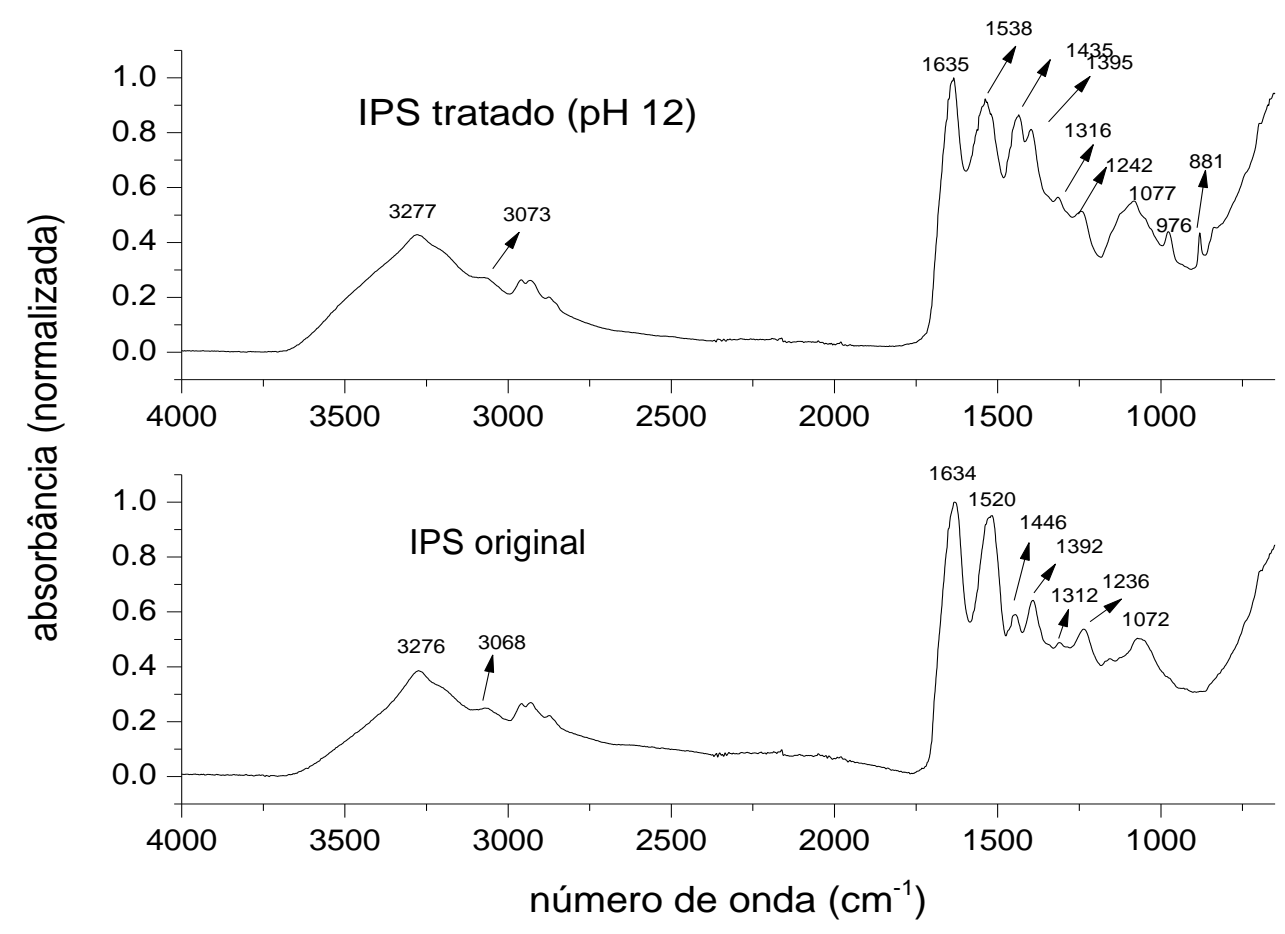

Figura 11. Espectros de infravermelho obtidos por FT-IR para amostra de isolado proteico de soja original e após tratamento alcalino-térmico.

Os espectros de infravermelho mostrados na Figura 11 mostram posições das bandas mostradas na Tabela 10:

Tabela 10. Posições das bandas encontradas nos espectros de infravermelho dos isolados proteicos de soja original e tratado.

\begin{tabular}{lccccc}
\hline \multirow{2}{*}{ Amostra } & \multicolumn{5}{c}{ Posição da banda (cm ${ }^{-1}$ ) } \\
\cline { 2 - 6 } & Amida A & Amida B & Amida I & Amida II & Amida III \\
\hline IPS original & 3276 & 3068 & 1635 & 1520 & $1392,1312,1236$ \\
IPS tratado & 3277 & 3072 & 1634 & 1538 & $1395,1316,1242$ \\
\hline
\end{tabular}

A banda amida A, que ocorreu a $3276 \mathrm{~cm}^{-1}$ para o IPS original e a $3277 \mathrm{~cm}^{-1}$ para o IPS tratado, é a manifestação do estiramento do grupo $\mathrm{N}-\mathrm{H}$ da amida, enquanto que a banda amida $\mathrm{B}$ (estiramento $\mathrm{C}-\mathrm{H}$ dos grupos amida) ocorreu a $3068 \mathrm{~cm}^{-1}$ para o IPS original e para $3072 \mathrm{~cm}^{-1}$ para o IPS tratado. Tais diferenças não são consideráveis, e tais bandas são típicas para o espectro de infravermelho de proteínas e compostos proteicos (SIONKOWSKA et al., 2010). A banda denominada amida I é causada pelo estiramento do grupo $\mathrm{C}=\mathrm{O}$, sendo que ocorreu no comprimento de $1635 \mathrm{~cm}^{-1}$ no IPS original e a $1634 \mathrm{~cm}^{-1}$ no IPS tratado, evidenciando alguma mudança na cadeia polipeptídica após o tratamento alcalino-térmico. Por sua vez, a banda amida II, que é causada pelo estiramento da ligação 
C-N e pela deformação angular da ligação $\mathrm{N}-\mathrm{H}$, também se alterou de $1520 \mathrm{~cm}^{-1}$ no IPS original para o comprimento de onda igual a $1538 \mathrm{~cm}^{-1}$ no IPS tratado. As bandas características da região do espectro denominada amida III também se alteraram, respectivamente, de 1392, 1312 e $1236 \mathrm{~cm}^{-1}$ para 1395, 1316 e 1242. Tais bandas estão relacionadas com o estiramento dos grupos $\mathrm{C}-\mathrm{N}$ e N-H na superfície de flexão das ligações amida e vibrações dos grupos $\mathrm{CH}_{2}$ da glicina e da prolina (MANTSCH E CHAPMAN, 1996). A banda a $1072 \mathrm{~cm}^{-1}$ se refere às vibrações de dobramento no plano ("rocking") do grupo $\mathrm{NH}_{3}{ }^{+}$da lisina (KRIMM E BANDEKAR, 1986). Tal banda se alterou ligeiramente no espectro do IPS tratado, passando a $1077 \mathrm{~cm}^{-1}$.

No espectro de infravermelho do IPS tratado, ocorreram duas bandas que inexistiam no espectro do IPS original: 976 e $881 \mathrm{~cm}^{-1}$. Tais bandas são provavelmente devidas à exposição do aminoácido triptofano após o tratamento alcalino-térmico, sendo que tal aminoácido contém um anel indol. Mohan et al. (1999) atribuem a banda de $976 \mathrm{~cm}^{-1}$ à deformação fora do plano do grupo $\mathrm{C}-\mathrm{H}$ e ao estiramento $\mathrm{C}-\mathrm{N}-\mathrm{H}_{2}$ do triptofano, e a banda a $881 \mathrm{~cm}^{-1}$ à deformação do esqueleto do anel indol no plano. Tais bandas não apareceram no espectro do IPS original, pois provavelmente o aminoácido triptofano, que é altamente hidrofóbico, estaria envolvido em interações com outros grupos hidrofóbicos que impediam as citadas deformações.

\subsubsection{HIDROFOBICIDADE SUPERFICIAL}

A determinação da hidrofobicidade superficial pode ser determinada por meio de espectrofluorimetria utilizando-se marcadores moleculares com características de fluorescência. A sonda ANS - ácido 8-anilino-1-naftalenosulfônico (nome IUPAC 8(phenylamino)-1-naphthalenesulfonic acid) cuja fórmula estrutural está representada na Figura 12. Sua estrutura possui 3 anéis aromáticos conferindo a esta molécula, entre outras capacidades, a de se associar a zonas hidrofóbicas proteicas. Esta sonda, em método descrito por Hayakawa (1985), vem sendo amplamente utilizada como marcador fluorescente para proteínas.

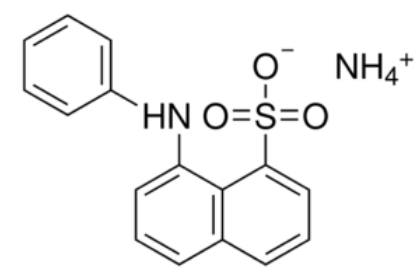

Figura 12. Fórmula estrutural do ácido 8-anilino-1-naftalenosulfônico. Fonte: Sigma-Aldrich (2014) 
As Figura 13 a 15 mostram as intensidades de fluorescência obtidas para as amostras de IPS original, IPS tratado em pH 12 e IPS tratado em pH 9, respectivamente. Tais curvas foram normalizadas em relação aos diferentes teores proteicos das amostras, descritos na Tabela 11:

Tabela 11. Concentrações proteicas do sobrenadante das soluções após centrifugação utilizadas nos ensaios de hidrofobicidade superficial.

\begin{tabular}{cc}
\hline Amostra & $\begin{array}{c}\text { Concentração } \\
\text { de proteína } \\
\text { do sobrenadante }(\mathbf{g} / \mathbf{L})\end{array}$ \\
\hline IPS original & 0,105 \\
pH $\mathbf{9}$ & 0,253 \\
pH 12 & 0,945 \\
\hline
\end{tabular}

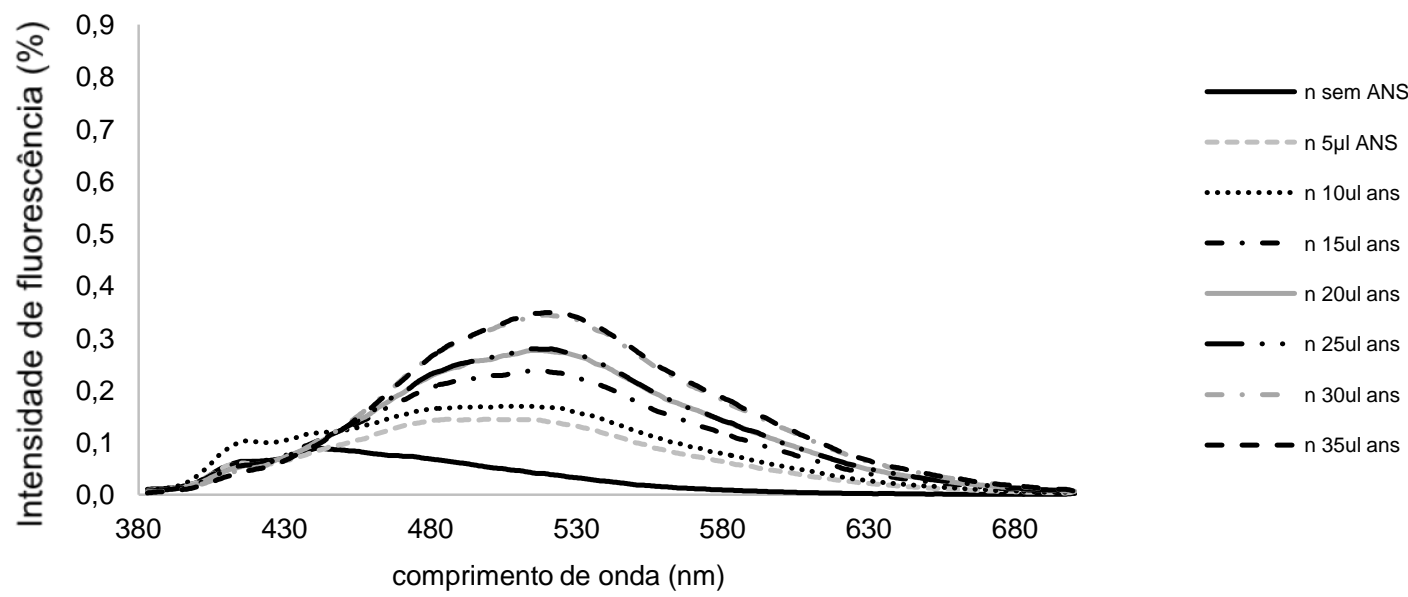

Figura 13. Curvas de intensidade de fluorescência obtidas no ensaio de hidrofobicidade superficial para amostras de isolado proteico de soja original.

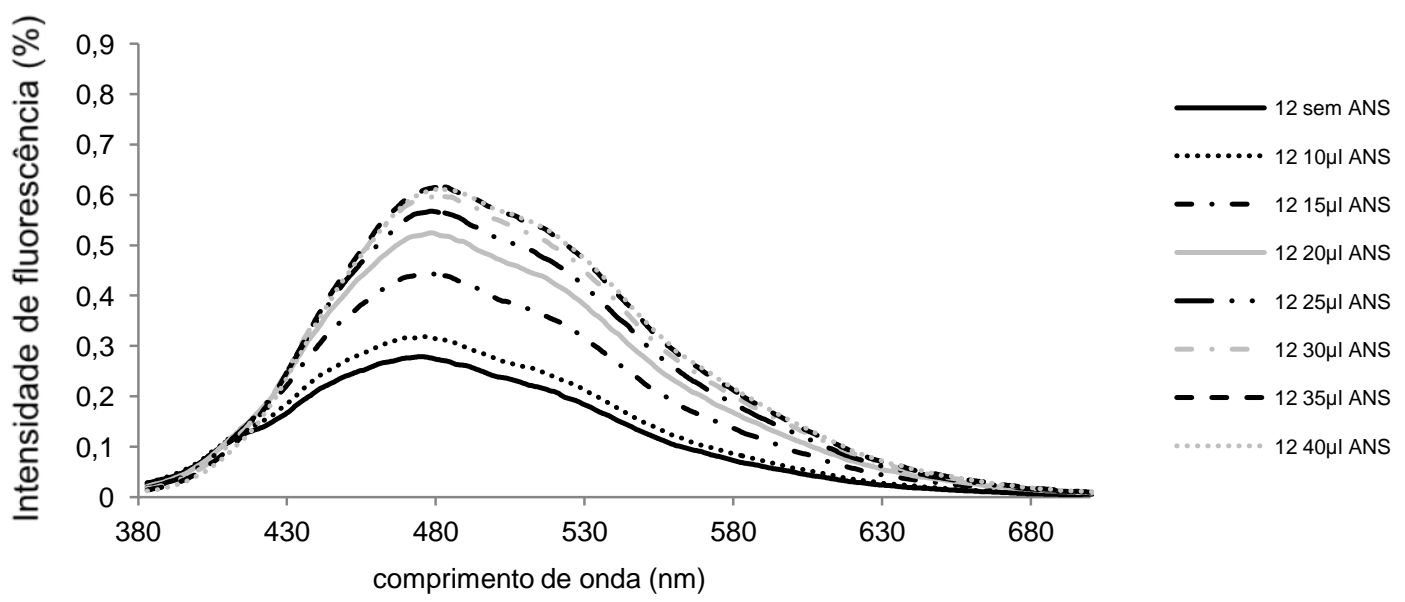

Figura 14. Curvas de intensidade de fluorescência obtidas no ensaio de hidrofobicidade superficial para amostras de isolado proteico de soja tratado, dispersas em pH 12 . 


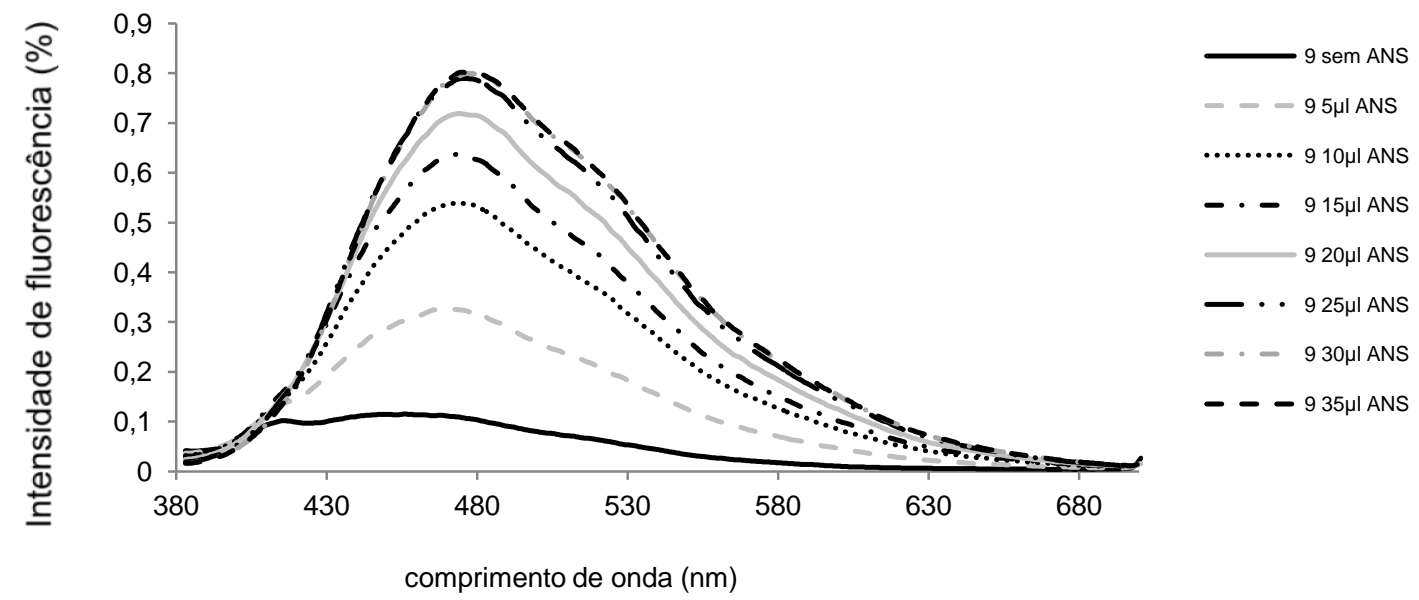

Figura 15. Curvas de intensidade de fluorescência obtidas no ensaio de hidrofobicidade superficial para amostras de isolado proteico de soja tratado, dispersas em $\mathrm{pH} 9$.

A Figura 16 representa o comportamento da hidrofobicidade superficial de cada amostra em relação a quantia de sonda ANS adicionada. Observa-se que a hidrofobicidade superficial da amostra de IPS tratado, em pH 12, foi muito menor do que os valores obtidos para as duas outras amostras, qualquer que fosse a quantidade de sonda ANS adicionadas. Tal fato pode ser devido à formação de rearranjos das cadeias polipeptídicas resultando na formação de agregados proteicos, cujas regiões mais hidrofóbicas estão localizadas no interior do agregado e inacessíveis para a sonda ANS. De acordo com Sorgentini et al. (1995), quanto maior o grau de desnaturação alcançado, maior tendência da formação de agregados haverá, devido ao aumento das interações hidrofóbicas.

Outra razão para a falta de resposta no uso da sonda ANS pode estar no fato de ela ser uma sonda aniônica, que pode não ter se ligado às zonas hidrofóbicas devido às cargas negativas presentes nas cadeias polipeptídicas em $\mathrm{pH} 12$. 


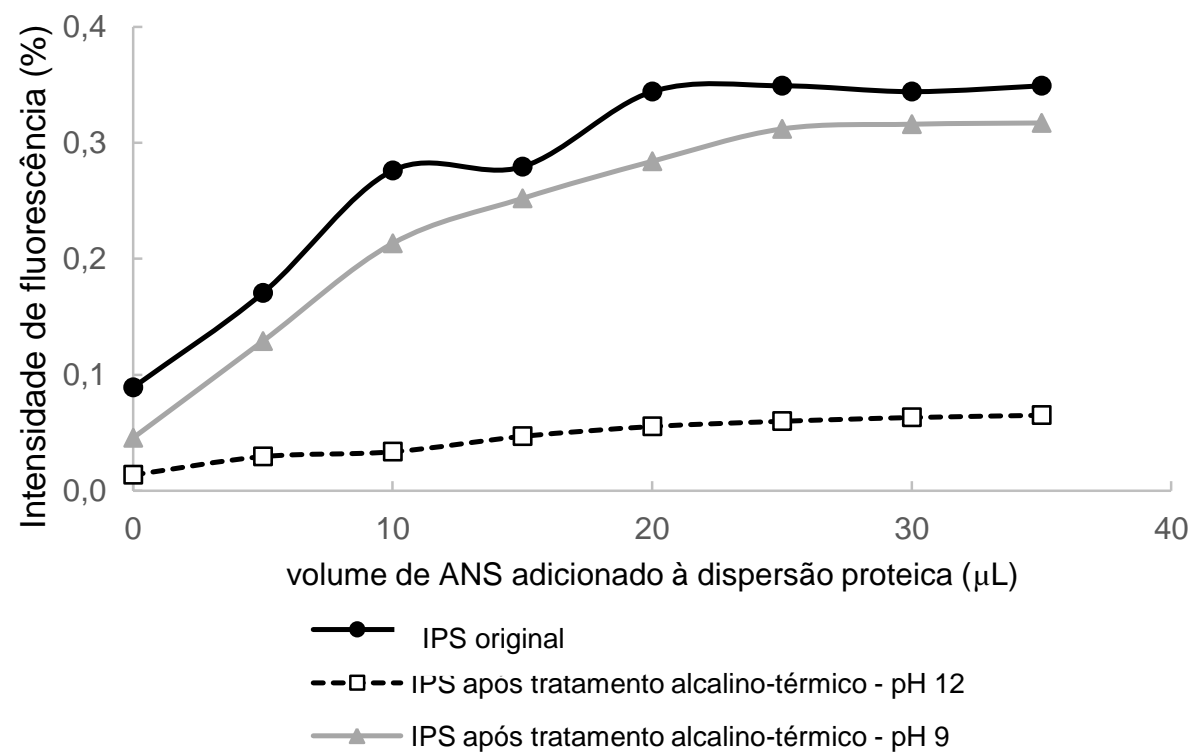

Figura 16. Curvas obtidas do ensaio de hidrofobicidade superficial para amostras de IPS original (n), tratados com pH 9 (9) e pH 12 (12), ambos a 0,1 g/L de teor proteico dos sobrenadantes.

\subsubsection{TENSÃO INTERFACIAL}

Os valores de tensão interfacial entre as dispersões de IPS tratado e estearina de palma, em diferentes condições de $\mathrm{pH}$, podem ser visualizados na Tabela 12:

Tabela 12. Valores de tensão interfacial entre as fases oleosa (estearina de palma a $85^{\circ} \mathrm{C}$ ) e aquosa, utilizando-se como tensoativo dispersões de IPS após tratamento alcalino-térmico, em diferentes valores de $\mathrm{pH}$.

\begin{tabular}{cc}
\hline $\mathbf{p H}$ & $\mathbf{T}(\mathbf{m N} / \mathbf{m})$ \\
\hline 3 & $6,68^{\mathrm{a}} \pm 0,96$ \\
5 & $8,29^{\mathrm{a}} \pm 0,22$ \\
7 & $7,52^{\mathrm{a}} \pm 0,57$ \\
9 & $6,62^{\mathrm{a}} \pm 0,72$ \\
12 & $1,76^{\mathrm{b}} \pm 0,08$
\end{tabular}

Valores médios com índices de mesma letra representam valores sem diferença significativa (Teste Tukey a 95\% de confiança). Médias e desvios padrões obtidos a partir de 3 ensaios experimentais.

É evidente, a partir dos resultados da Tabela 12, que entre o pH 3 e $\circ \mathrm{pH} 9$, a tensão interfacial não foi alterada. Somente na condição de pH 12 o IPS tratado foi capaz de produzir uma mudança significativa no valor de tal parâmetro, provavelmente devido à exposição de grupos hidrofóbicos (ver item 5.1.4), capazes de interagir mais eficientemente com a fase oleosa. 


\subsubsection{PERFIL DE AMINOÁCIDOS}

Proteínas submetidas a tratamento alcalino-térmicos drásticos podem vir a sofrer alterações permanentes, consequência de reações químicas do tipo cross-linking, $\beta$ eliminação ou racemização de aminoácidos (DAMODARAN et al., 2010; DEMAN, 1999; BARAC et al., 2004).

Os resultados dos perfis de aminoácidos obtidos por cromatografia líquida de alta eficiência seguida de quantificação por espectrofotometria no U.V. estão representados na Figura 17. Nota-se que o perfil de aminoácidos resultante é característico de um isolado proteico de soja o que sugere que não houve reações de $\beta$-eliminação que causariam variação nas quantidades das frações de cada aminoácido identificado.

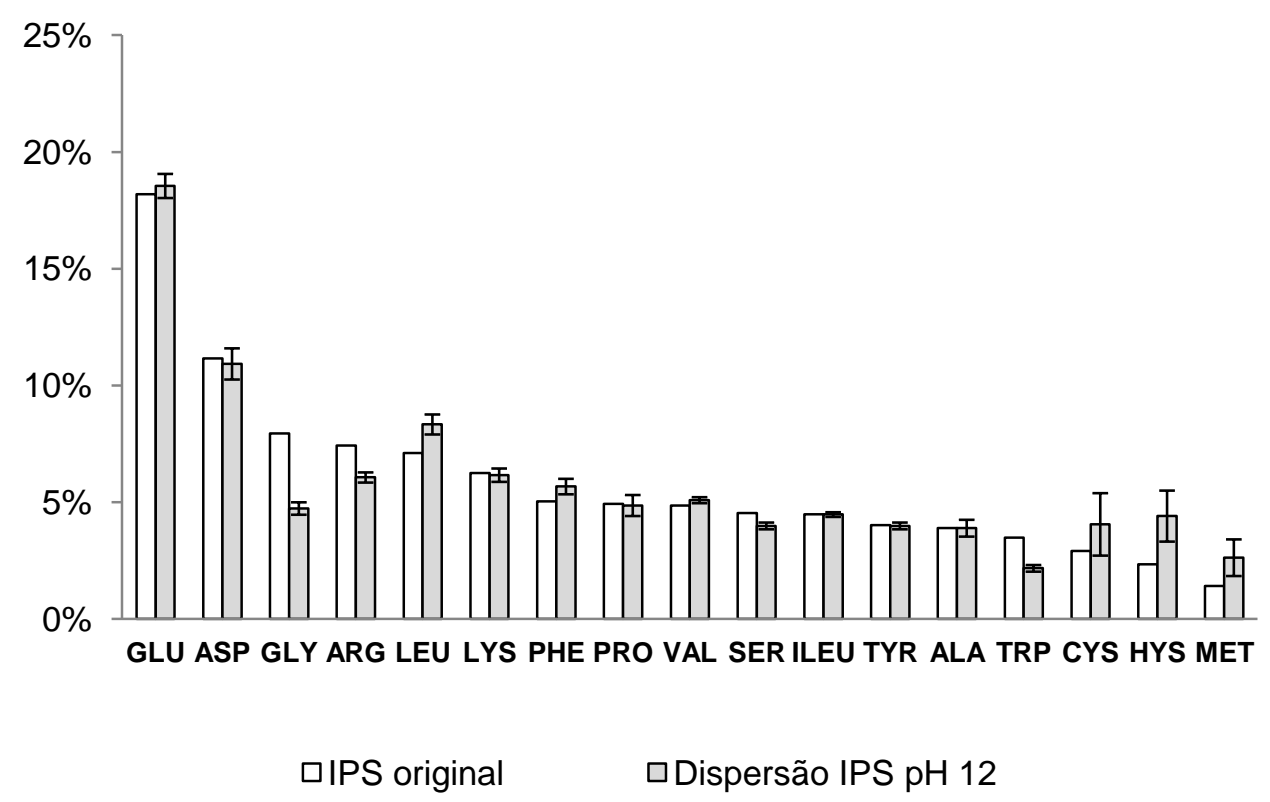

Figura 17. Composição em aminoácidos totais em amostras de isolado proteico de soja original e após tratamento alcalino-térmico.

\subsubsection{CALORIMETRIA DIFERENCIAL DE VARREDURA}

A Figura 18 mostra os termogramas por calorimetria diferencial de varredura do IPS original $(\mathrm{N})$ e após o tratamento alcalino-térmico. Os resultados demonstram que o IPS já se encontrava desnaturado, pois não foi detectado qualquer fenômeno endotérmico. Por sua vez, para a amostra de IPS após o tratamento alcalino térmico nota-se a presença de um fenômeno exotérmico em $56,41^{\circ} \mathrm{C}$, com variação de entalpia de $14,9 \mathrm{~J} / \mathrm{g}$. 


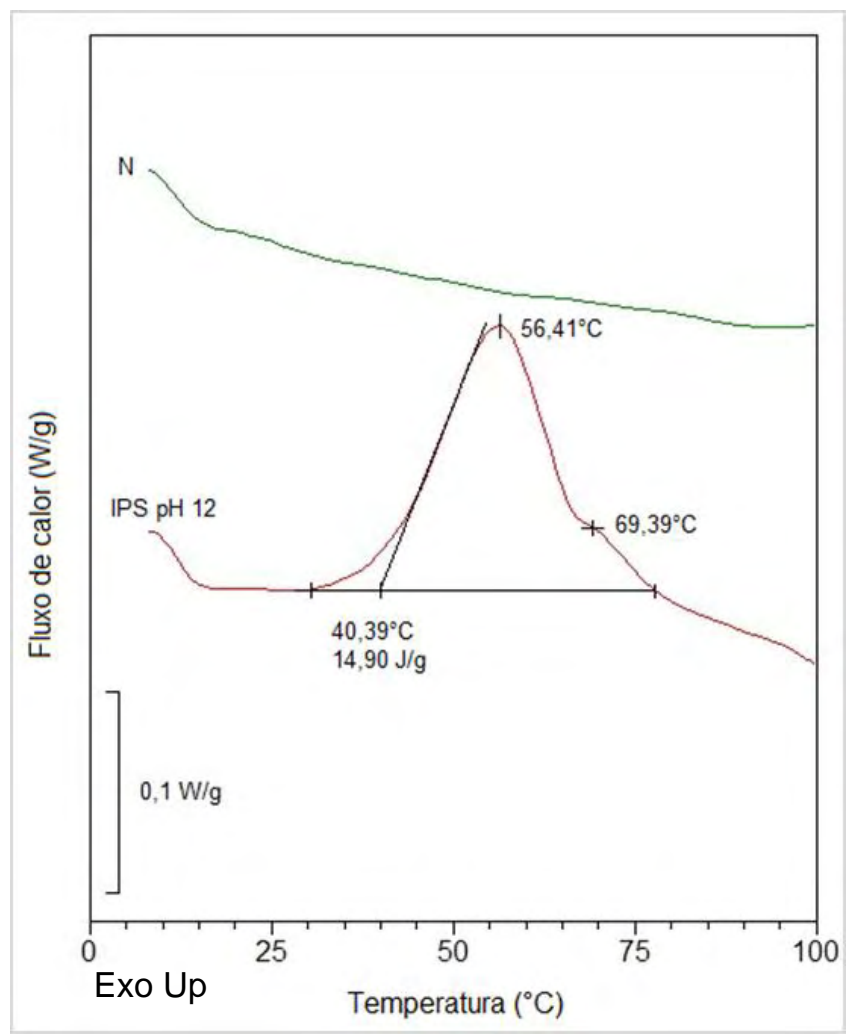

Figura 18. Termogramas obtidos por calorimetria diferencial de varredura para o isolado proteico de soja original e tratado em $\mathrm{pH} 12$.

Segundo Privalov e Khechinashvili (1974), fenômenos exotérmicos em dispersões de proteínas estão relacionados com agregação de cadeias polipeptídicas e com o rompimento de interações hidrofóbicas. Como o IPS tratado se encontrava hidrolisado (conforme resultados de eletroforese SDS-Page, Figura 10), provavelmente nesta condição houve a produção de uma grande quantidade de cadeias polipeptídicas. O aumento da temperatura no ensaio de DSC pode ter provocado a agregação de tais cadeias, resultando no fenômeno exotérmico detectado. O tratamento alcalino-térmico também resultou na exposição de grupos hidrofóbicos (conforme explicado no item 6.1.4, referente à espectroscopia de infravermelho), que poderiam estar mais disponíveis para interagir entre si. Neste caso, o aumento da temperatura pode ter provocado o rompimento de tais interações, contribuindo para a ocorrência do fenômeno exotérmico. 


\subsection{CARACTERIZAÇÃO DA ESTEARINA DE PALMA}

As análises de caracterização da estearina de palma mostraram que o material lipídico utilizado possui densidade de $0,8728 \pm 0,0053 \mathrm{~g} / \mathrm{mL}\left(\mathrm{a} 85^{\circ} \mathrm{C}\right)$. Por sua vez, a Figura 19 mostra o espectro resultante da análise de difratometria de raios-X da estearina de palma pura:

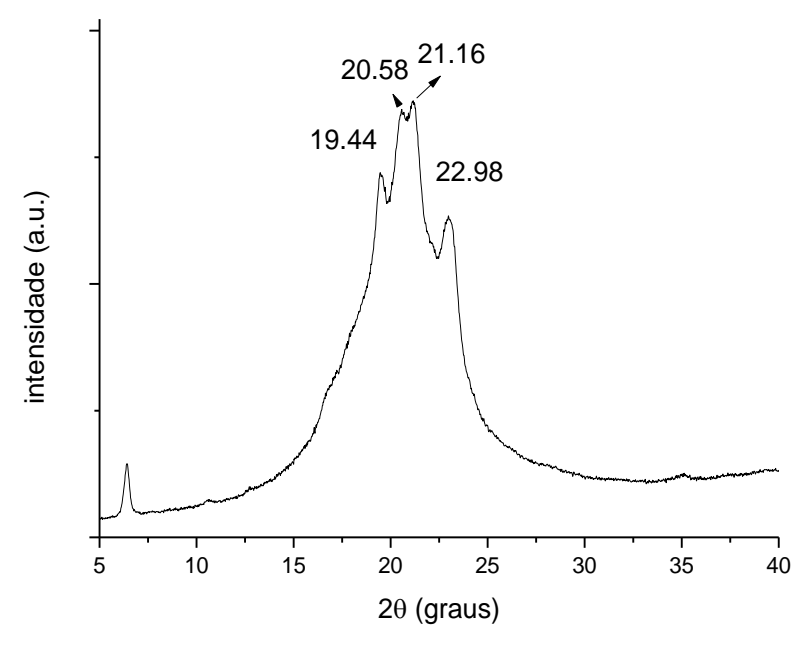

Figura 19. Difratograma de raios- $X$ da estearina de palma pura.

É possível no difratograma da Figura 19 identificar picos nos valores indicados de $2 \theta$, característicos da estrutura das formas $\beta^{\prime}$ e $\beta$. Entretanto, o difratograma que também mostra claramente que a estearina de palma utilizada na produção das micropartículas lipídicas sólidas é altamente amorfa, conforme indicado pela subida da linha de base a partir de $2 \theta$ igual a $15^{\circ}$. Tal característica é altamente desejada em matérias-primas utilizadas na produção de micropartículas lipídicas sólidas, uma vez que um alto grau de amorfização da matriz significa que o núcleo lipídico será altamente desorganizado do ponto de vista estrutural. Matrizes lipídicas desorganizadas são interessantes pois retículos cristalinos menos ordenados favorecem a inclusão dos bioativos no núcleo lipídico durante o processo de encapsulação, e diminuem a chance de expulsão de tais bioativos, sendo também possível controlar melhor a liberação dos mesmos (ATTAMA e MÜLLER-GOYMANN, 2008; MÜLLER et al., 2002). Tal resultado era esperado, uma vez que a estearina de palma é formada por uma grande variedade de moléculas de triacilgliceróis, o que favorece a estruturação lipídica em formas cristalinas diversas. 
Por sua vez, a Figura 20 mostra o termograma obtido por DSC da estearina de palma pura utilizada neste trabalho de Mestrado. É possivel verificar que a matéria-prima lipídica é composta por diversas frações, sendo mais rica em triacilgliceróis contendo ácido palmítico, fato comprovado pela transição de fases endotérmica a 55,9॰ C.

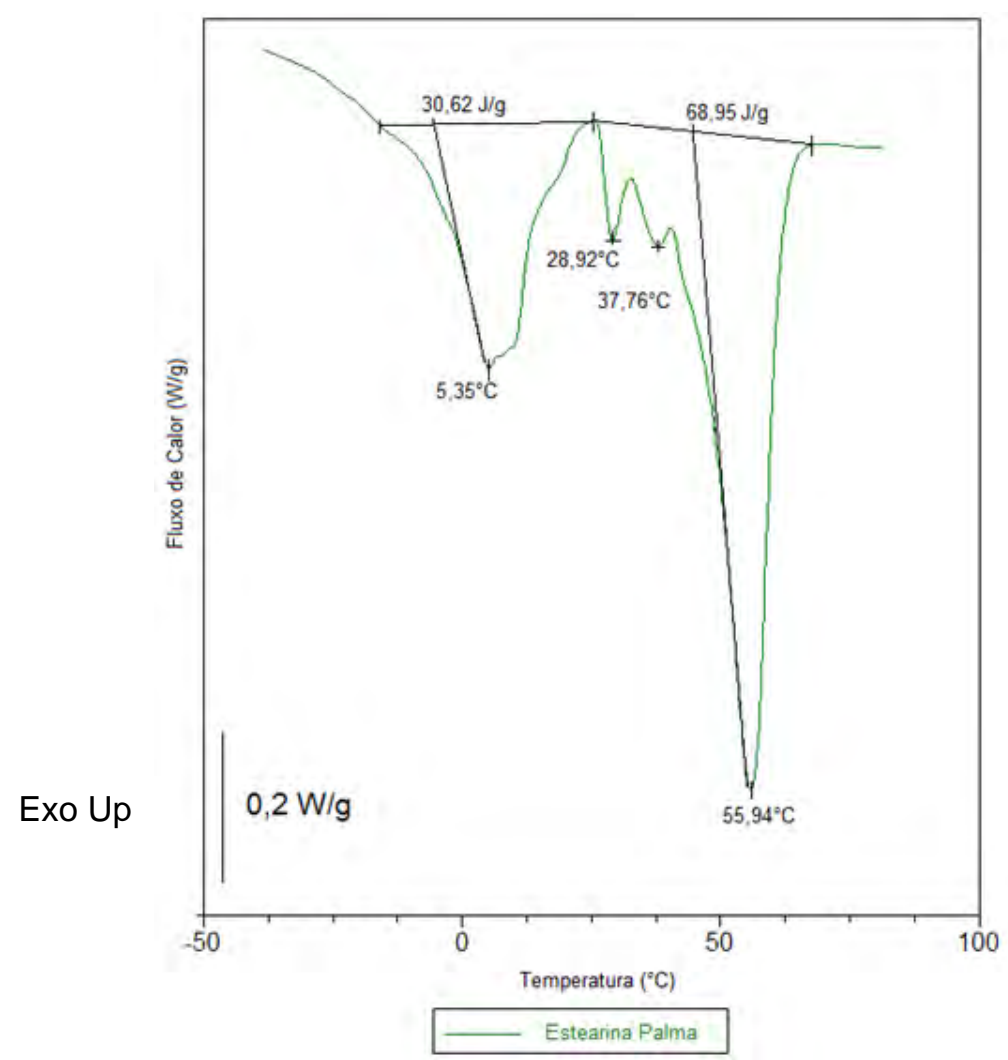

Figura 20. Termograma obtido por calorimetria diferencial de varredura para a estearina de palma pura.

\subsection{CARACTERIZAÇÃO FÍSICO-QUÍMICA E MONITORAMENTO DA ESTABILIDADE DAS MICROPARTÍCULAS LIPÍDICAS CONTENDO BETA-CAROTENO}

O aspecto visual macroscópico das amostras contendo micropartículas lipídicas sólidas encapsulando beta-caroteno pode ser verificado na Figura 21. 


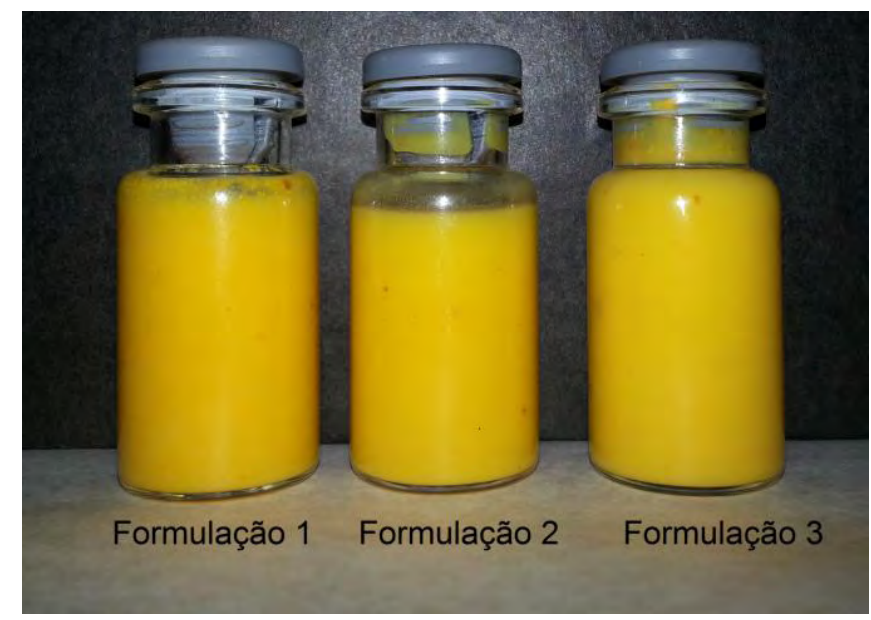

Figura 21. Aspecto visual das micropartículas lipídicas sólidas encapsulando beta-caroteno.

Foi realizado o monitoramento das dispersões de micropartículas lipídicas sólidas ao longo do tempo de armazenagem, em relação à distribuição do tamanho de partícula, e o resultado pode ser visto nas Figuras 22 a 24:

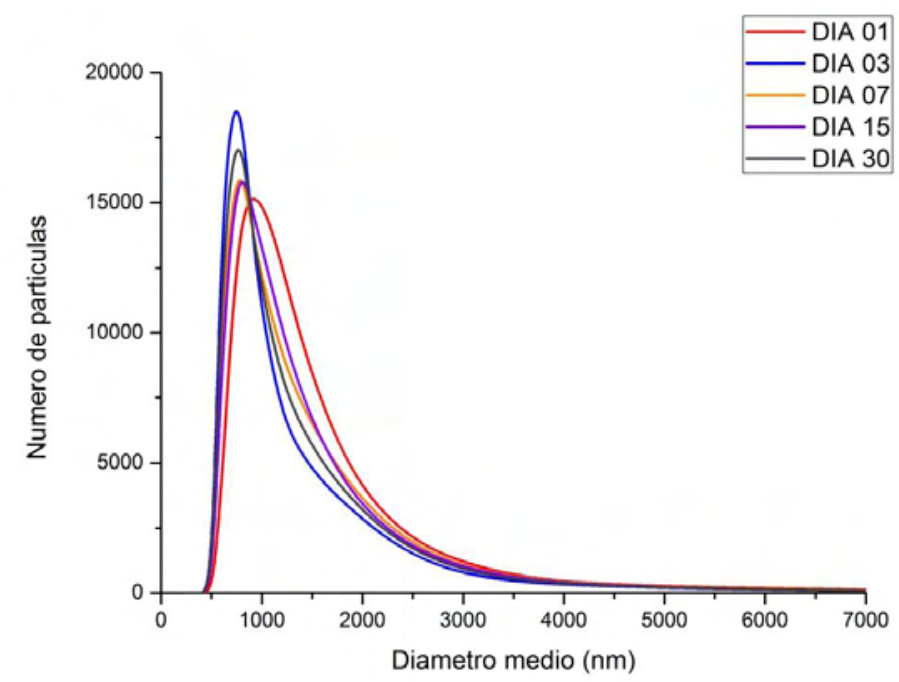

Figura 22. Curvas de distribuição de tamanho das micropartículas lipídicas sólidas - formulação 1 (sem tocoferol). 


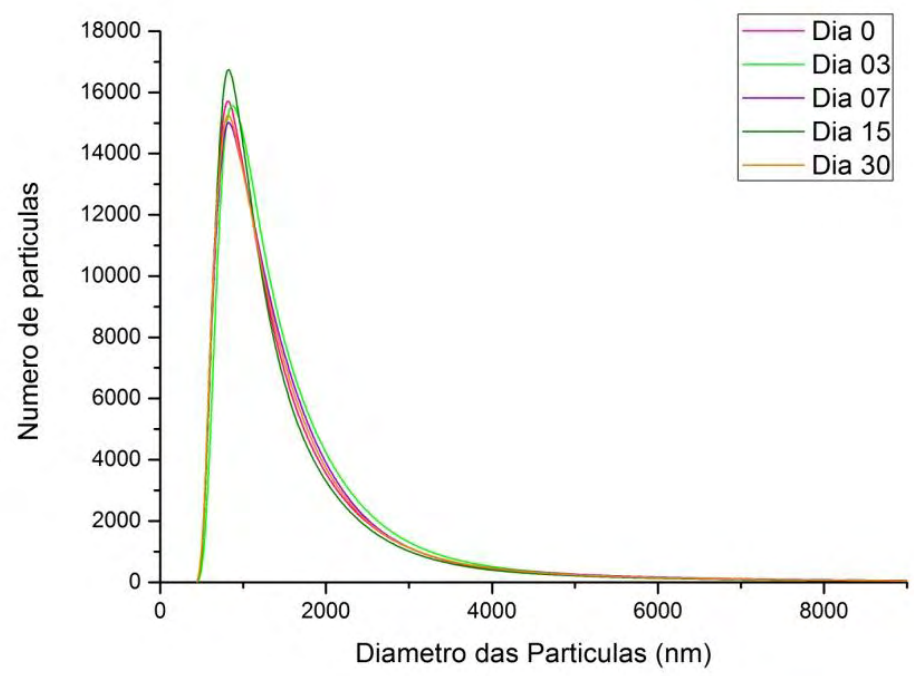

Figura 23. Curvas de distribuição de tamanho de das micropartículas lipídicas sólidas - formulação 2 (razão 2:1 beta-caroteno:tocoferol)

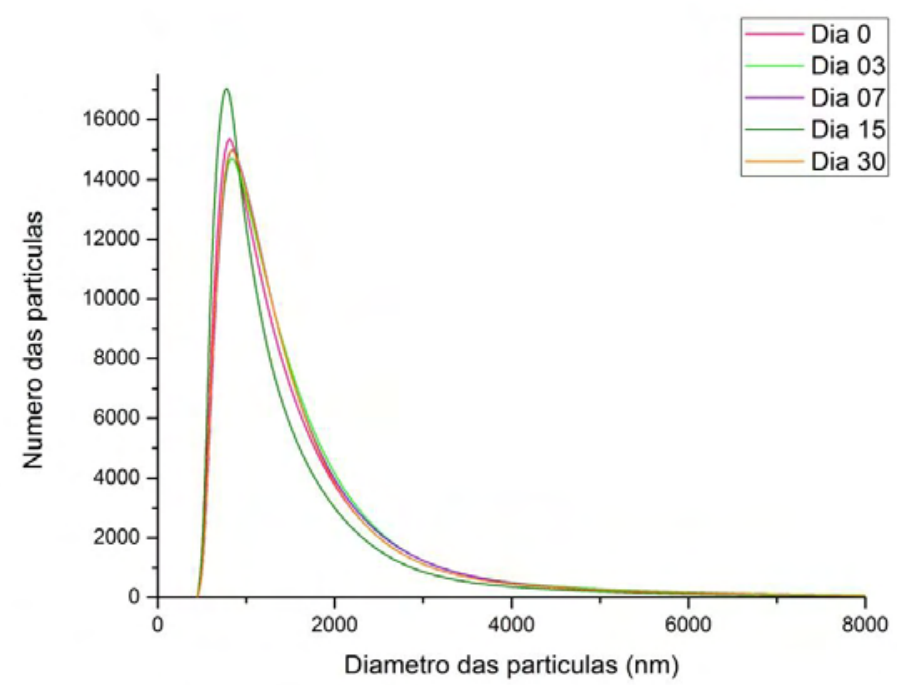

Figura 24. Curvas de distribuição de tamanho de das micropartículas lipídicas sólidas - formulação 3 (razão 1:1 beta-caroteno:tocoferol)

As curvas de distribuição de tamanho de partícula mostram sistemas extremamente estáveis em relação a este parâmetro. O diâmetro médio, em todos os casos, ficou próximo a $1500 \mathrm{~nm}(1,5 \mu \mathrm{m})$.

Por sua vez, a Figura 25 mostra os valores de potencial zeta obtidos paras as 3 formulações de micropartículas lipídicas sólidas contendo beta-caroteno, ao longo de 30 
dias de monitoramento. Todos os valores se apresentaram abaixo de $-30 \mathrm{mV}$, o que indica ótima estabilidade do sistema coloidal (McCLEMENTS, 2004).

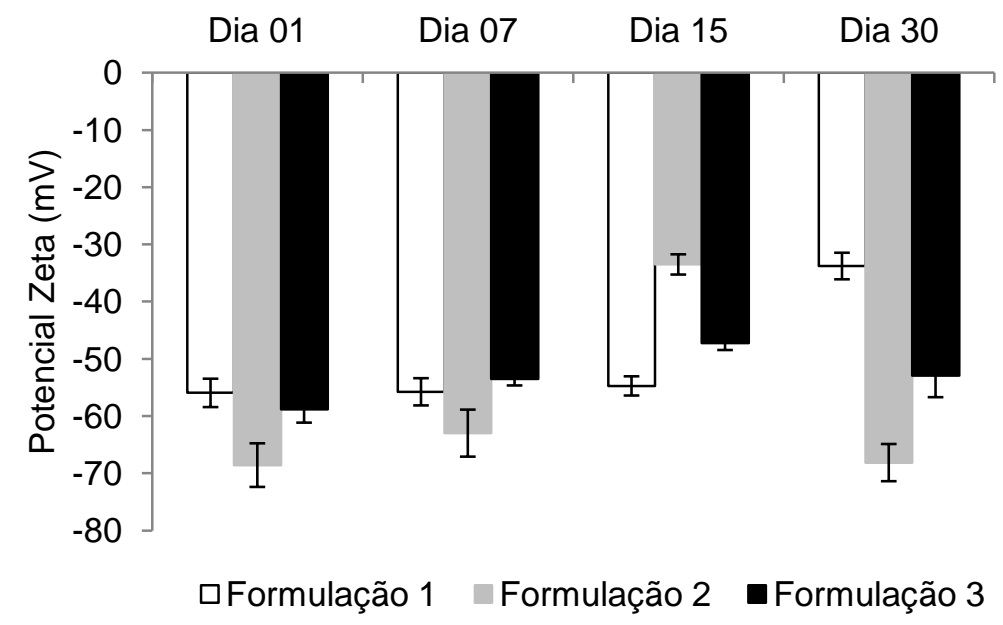

Figura 25. Valores de potencial zeta obtidos para as micropartículas lipídicas ao longo do tempo de armazenagem.

A Figura 26 mostra a concentração de beta-caroteno encapsulado ao longo do o tempo, para as três formulações de micropartículas lipídicas sólidas produzidas:

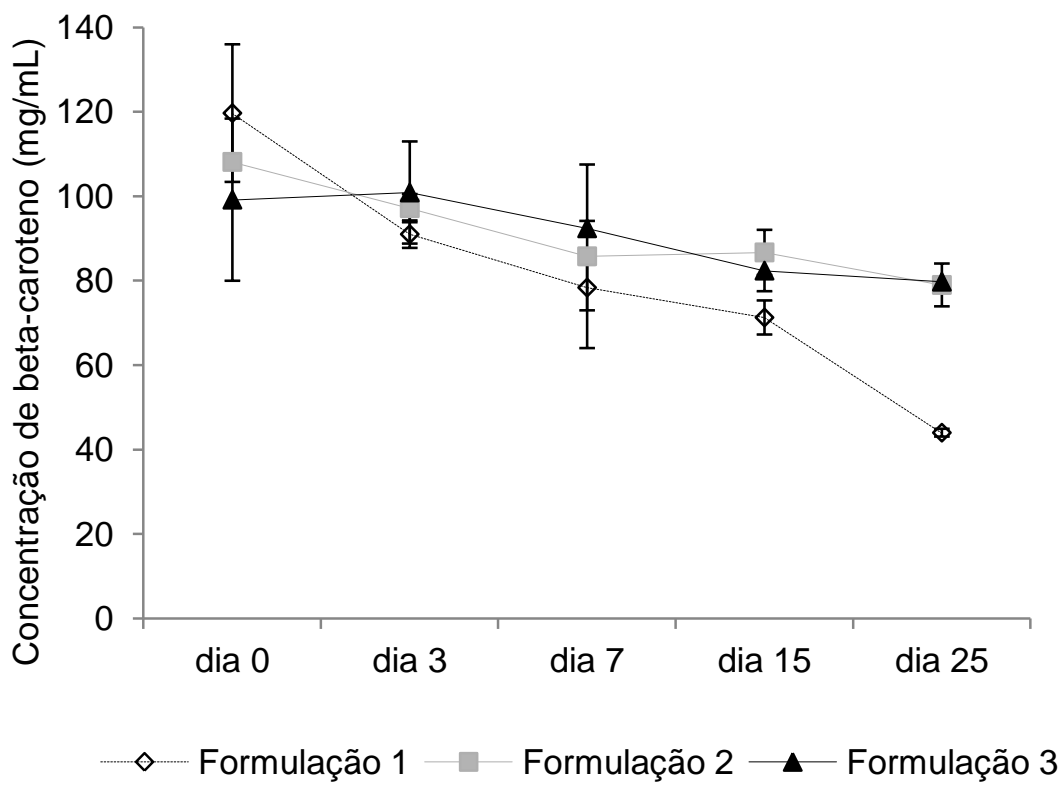

Figura 26. Perfil temporal de concentração de beta-caroteno nas dispersões de micropartículas lipídicas sólidas com diferentes proporções de alfa-tocoferol: Formulações 1, 2 e 3. 


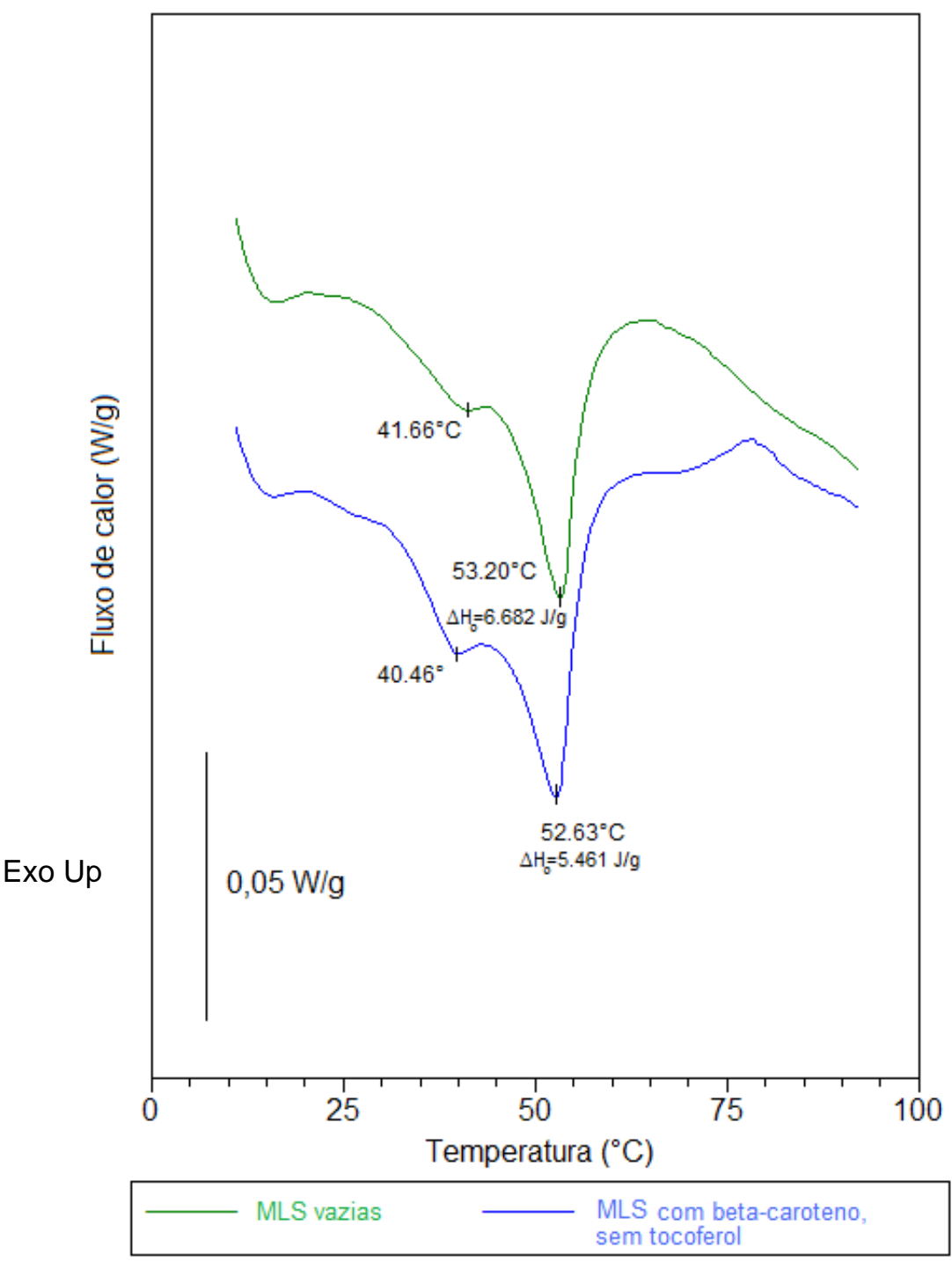

Figura 27: Termograma obtido por calorimetria diferencial de varredura das micropartículas lipídicas sólidas encapsulando beta-caroteno.

O termograma da Figura 27 mostra que não houve alterações no comportamento térmico das micropartículas lipídicas sólidas após a incorporação do beta-caroteno. $\mathrm{O}$ termograma mostra também a heterogeneidade da estrutura das micropartículas, uma vez que não há somente um pico de fusão definido. São identificadas duas transições de fase, a 40,4 e $52,6^{\circ} \mathrm{C}$, provavelmente às frações lipídicas ricas em ácido palmítico, o ácido graxo mais abundante na estearina de palma. Pode-se afirmar, portanto, que dependendo da temperatura de utilização das micropartículas lipídicas produzidas, elas se mostram totalmente sólidas (abaixo de $20^{\circ} \mathrm{C}$ ) ou parcialmente solidificadas (entre 20 e $75^{\circ} \mathrm{C}$ ). $\mathrm{Na}$ 
temperatura de armazenamento do iogurte (sob refrigeração), portanto, pode-se afirmar que as partículas estavam completamente solidificadas.

Os resultados obtidos nas Figura 22 a Figura 24 mostraram que as micropartículas lipídicas sólidas produzidas com estearina de palma para produção do núcleo lipídico, e com isolado proteico de soja hidrolisado como tensoativo, a $\mathrm{pH} 12$, e goma xantana na concentração de $0,3 \%$ como espessante, foram extremamente estáveis em relação ao tamanho de partícula durante 30 dias de armazenagem sob refrigeração. Além disso, se mostraram capazes de proteger o beta-caroteno da degradação, em diferentes graus, sendo esta capacidade muito mais pronunciada para as dispersões contendo alfa-tocoferol. Sendo assim, tais micropartículas se mostraram possíveis de incorporação em iogurte, e os resultados de tal adição são mostrados a seguir.

\subsection{INCORPORAÇÃO DE MICROPARTÍCULAS LIPÍDICAS SÓLIDAS ENCAPSULANDO BETA-CAROTENO EM IOGURTE}

\subsubsection{TESTES DE APLICAÇÃO PRELIMINARES}

Para a definição das quantidades de micropartículas lipídicas sólidas a serem adicionadas nos iogurtes, testou-se aplicações em concentrações variando de $1 \mathrm{a} 7 \%$ (em massa de dispersão) e foi feita a comparação colorimétrica com os iogurtes similares de mesmo sabor existentes no mercado, das marcas Nestlé e Vigor (Figura 27). Os valores de $L^{*}, a^{*}$ e b* encontrados estão mostrados na Figura 28.

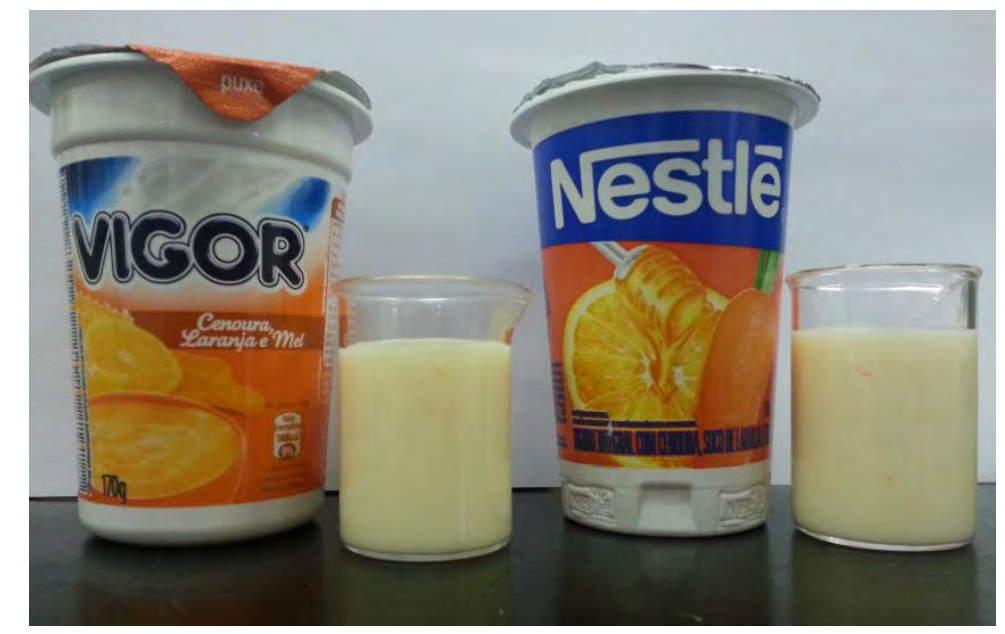

Figura 27. Imagens de amostras de amostras de iogurtes comerciais sabor cenoura, laranja e mel 


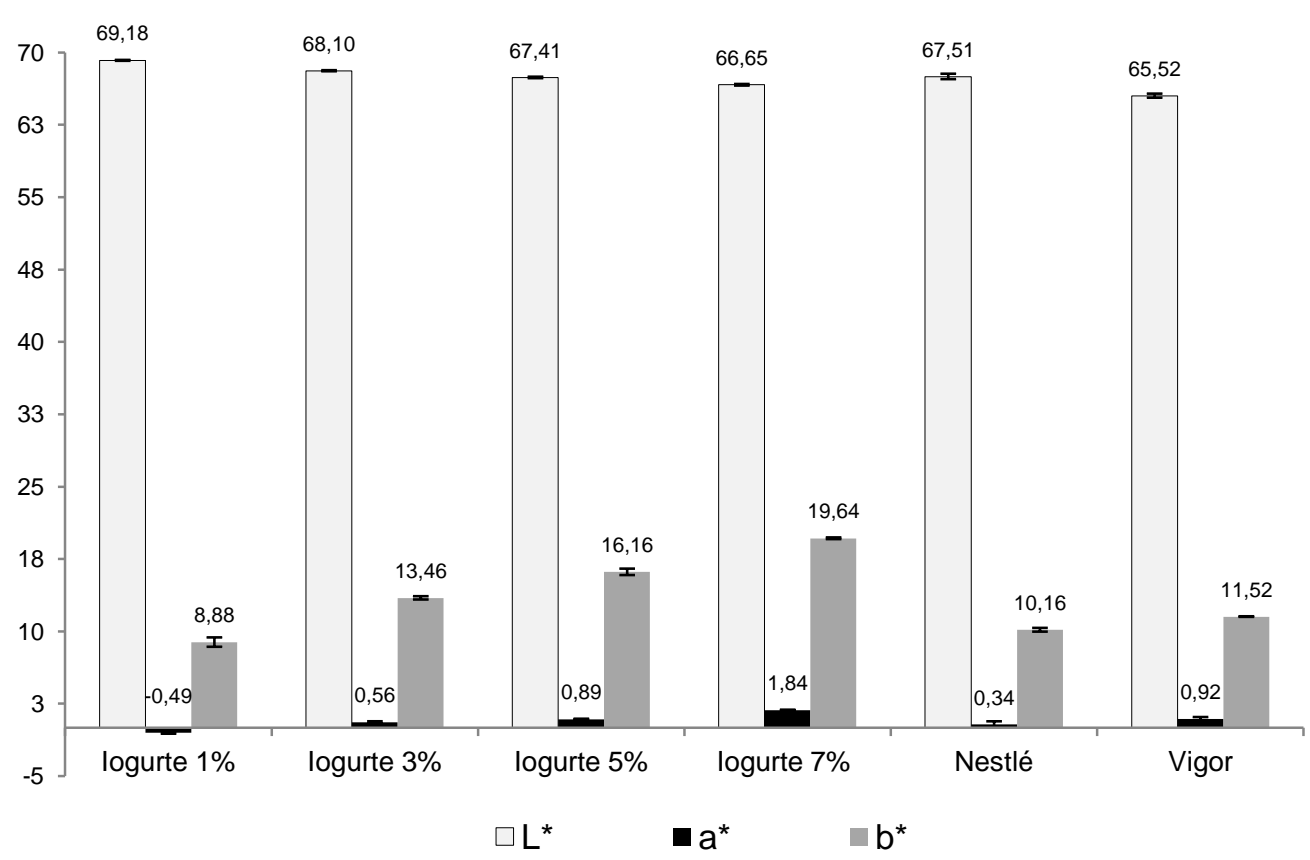

Figura 28. Parâmetros colorimétricos $L^{*} a^{*} b^{*}$ das amostras de iogurte em comparação com os produtos comerciais.

Observa-se que os iogurtes comerciais diferem um pouco no parâmetro a*, mantendo $L^{*}$ (média entre 66,6 e 67,5) e b* (média entre 10,1 e 11,5) sem grandes diferenças. Estes valores se equiparam às amostras testadas com aplicações entre 3 e $5 \%$. Na análise do parâmetro a*, notou-se que a incorporação de $5 \%$ de micropartículas lipídicas sólidas, resultou no valor de 0,89 , e aproximou-se do iogurte da marca Vigor $\left(a^{*}=0,92\right)$, enquanto a incorporação de $3 \%$ de micropartículas lipídicas sólidas se revelou mais próxima do valor encontrado para o parâmetro $a^{*}$ da marca Nestlé.

$\mathrm{Na}$ comparação global dos parâmetros $L^{*}, a^{*}$ e $b^{*}$ a quantidade incorporada que mais se aproximou dos produtos comerciais utilizados como referência neste estudo foi $5 \%$ (Figura 28).

Nas Figuras 29 e 30 pode-se visualizar o aspecto dos iogurtes produzidos com adição de micropartículas lipídicas sólidas contendo beta-caroteno, nos dias 0 e 15, respectivamente. 

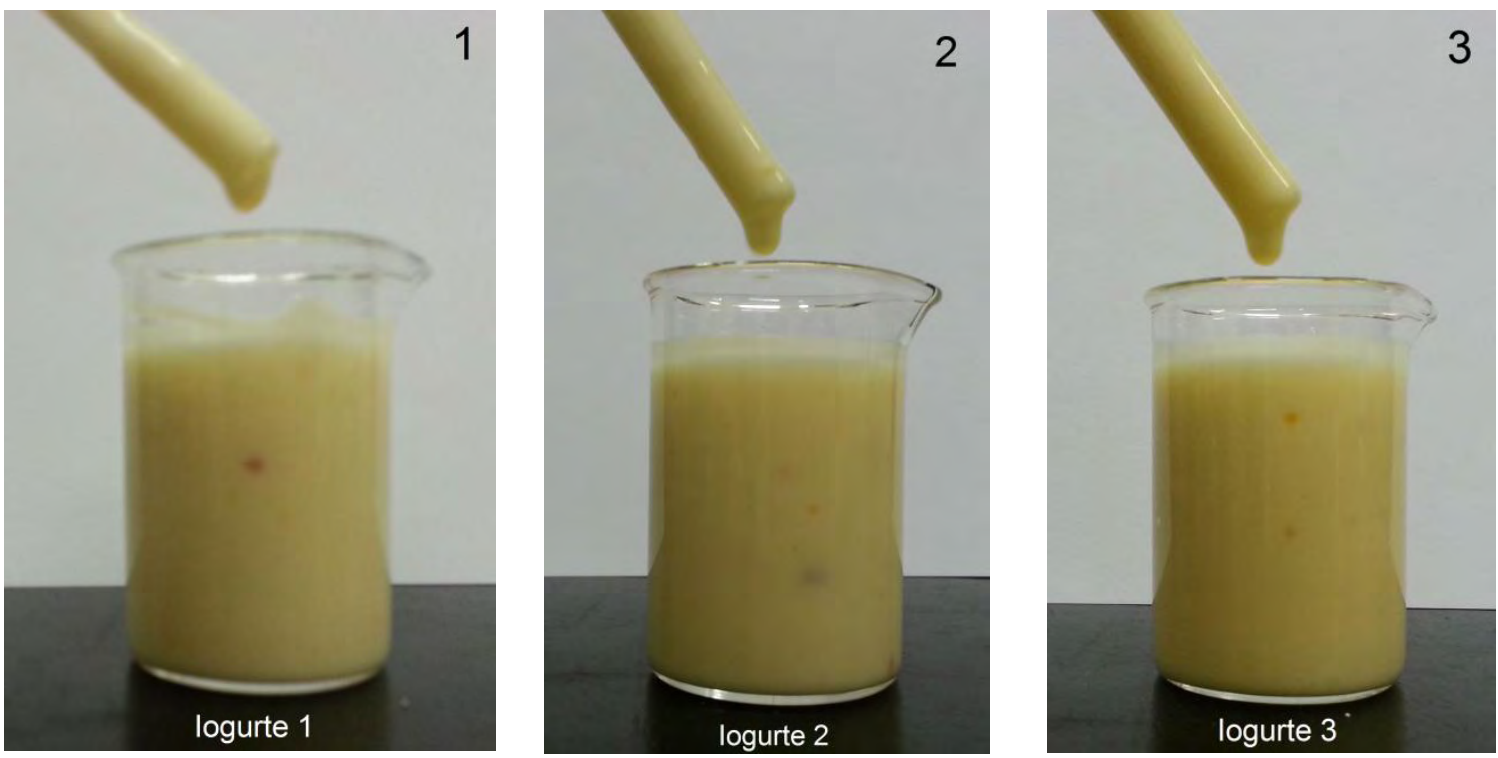

Figura 29. logurtes produzidos com partículas lipídicas com formulação sem alfa-tocoferol (1), com 1:2 de alfa-tocoferol: beta-caroteno (2) e 1:1(3) de alfa-tocoferol: beta-caroteno, no dia da produção (dia 0).

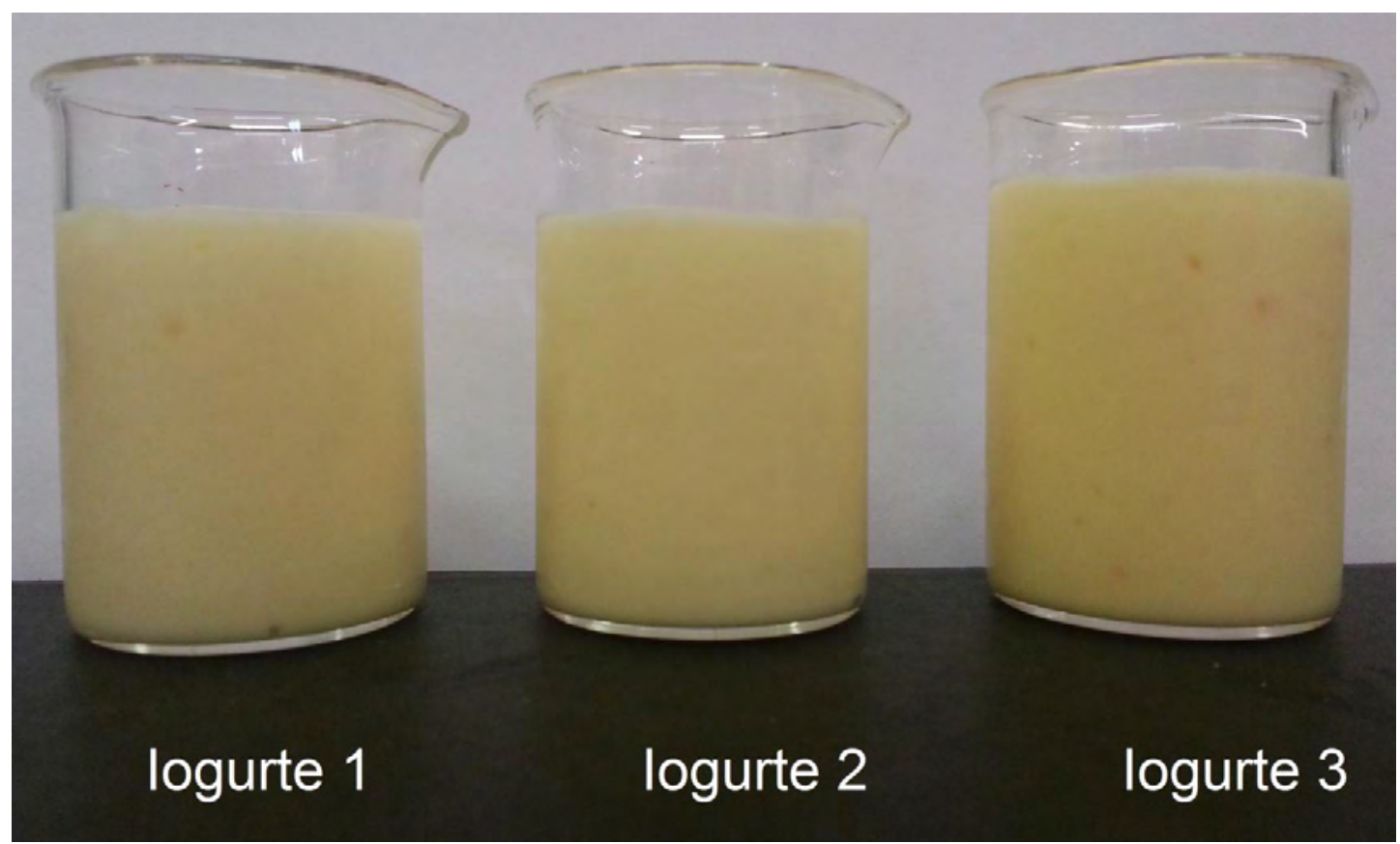

Figura 30. logurtes produzidos com partículas lipídicas com formulação sem alfa-tocoferol (logurte 1), com 1:2 de alfa-tocoferol: beta-caroteno (logurte 2) e 1:1 (logurte 3) de alfa-tocoferol: beta-caroteno, no $15^{\circ}$ dia de estocagem. 


\subsubsection{DETERMINAÇÃO DE DENSIDADE, GORDURA, PROTEÍNA E UMIDADE NOS IOGURTES}

A Tabela 13 mostra os valores de densidade e teores de gordura, proteína e umidade dos iogurtes produzidos:

Tabela 13. Caracterização físico-química dos iogurtes produzidos neste trabalho de Mestrado.

\begin{tabular}{ccccc}
\hline \multirow{2}{*}{ logurte } & \multicolumn{4}{c}{ Parâmetro } \\
\cline { 2 - 5 } & $\begin{array}{c}\text { Densidade } \\
(\mathbf{g} / \mathbf{m L})\end{array}$ & Gordura & Proteína & Umidade \\
\cline { 2 - 5 } $\mathbf{1}$ & $1,046 \pm 0,005$ & $2,75 \% \pm 0,35$ & $4,47 \pm 0,02$ & $81,1 \% \pm 0,01$ \\
$\mathbf{2}$ & $1,047 \pm 0,006$ & $2,75 \% \pm 0,00$ & $4,30 \pm 0,04$ & $80,2 \% \pm 0,01$ \\
$\mathbf{3}$ & $1,036 \pm 0,006$ & $2,63 \% \pm 0,18$ & $4,43 \pm 0,35$ & $80,9 \% \pm 0,002$ \\
branco & $1,029 \pm 0,009$ & $2,38 \% \pm 0,18$ & $4,52 \pm 0,16$ & $80,2 \% \pm 0,005$ \\
\hline
\end{tabular}

É evidente que a adição das micropartículas lipídicas sólidas não alterou significativamente nenhum dos parâmetros mensurados.

\subsubsection{DETERMINAÇÃO DE ACIDEZ EM ÁCIDO LÁTICO E PH}

Em relação à estabilidade ao longo do período de estocagem, foram monitorados os seguintes parâmetros: $\mathrm{pH}$, acidez titulável, cor instrumental e características reológicas. A Figura 31 mostra o comportamento do $\mathrm{pH}$ dos iogurtes produzidos ao longo da estocagem. É possível inferir que, apesar de as dispersões de partículas lipídicas possuírem pH 12, tal fato não provocou mudança significativa no $\mathrm{pH}$ do iogurte produzido, que permaneceu na faixa de 4,3 a 4,7. Segundo Robinson et al. (2006), valores de $\mathrm{pH}$ menores que 4 podem promover a sinérese do iogurte (separação do soro), uma vez que levaria à repulsão excessiva entre cargas (MATHIAS et al., 2013). Tal fato não ocorreu em nenhuma das formulações produzidas. 


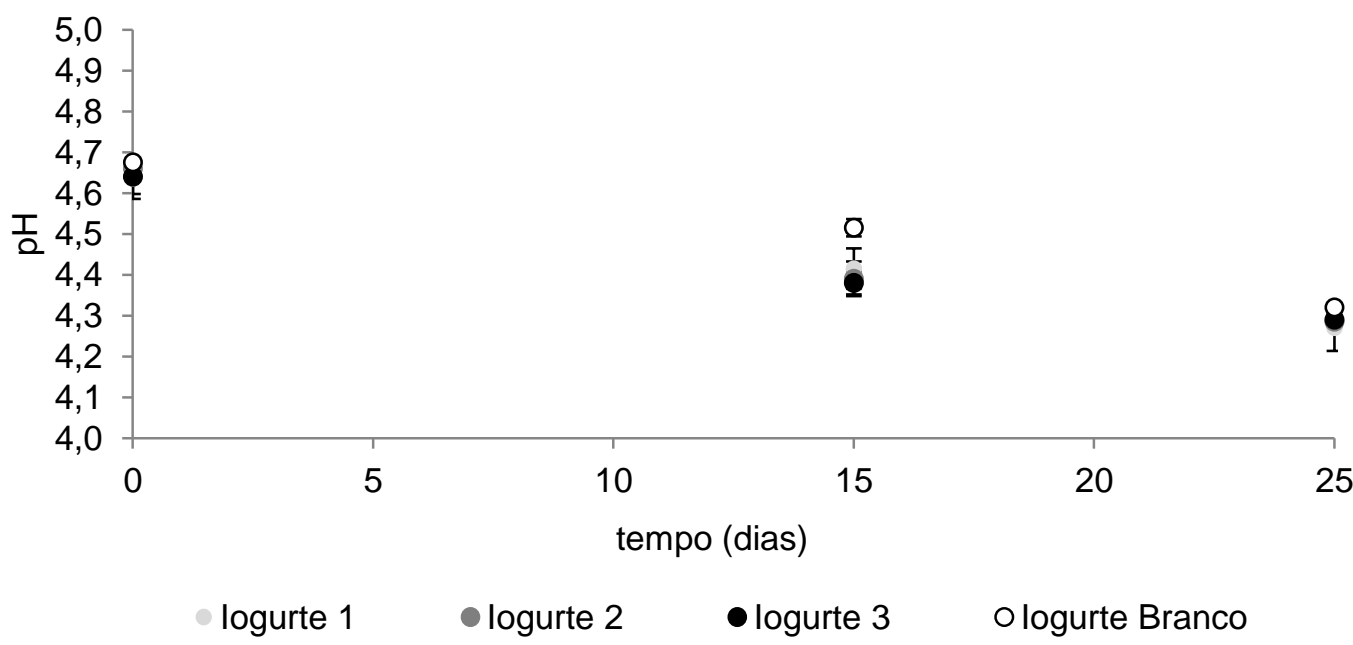

Figura 31. Valores de $\mathrm{pH}$ de amostras dos iogurtes produzidos, ao longo do período de armazenagem.

Por sua vez, a Figura 32 mostra os valores de acidez titulável detectada nos iogurtes produzidos, ao longo do tempo de armazenagem. Pode-se perceber, novamente, que são muito próximos dos valores obtidos para o iogurte branco, fato que confirma que a adição de partículas lipídicas sólidas contendo beta-caroteno também não provocou mudança em tal característica do produto.

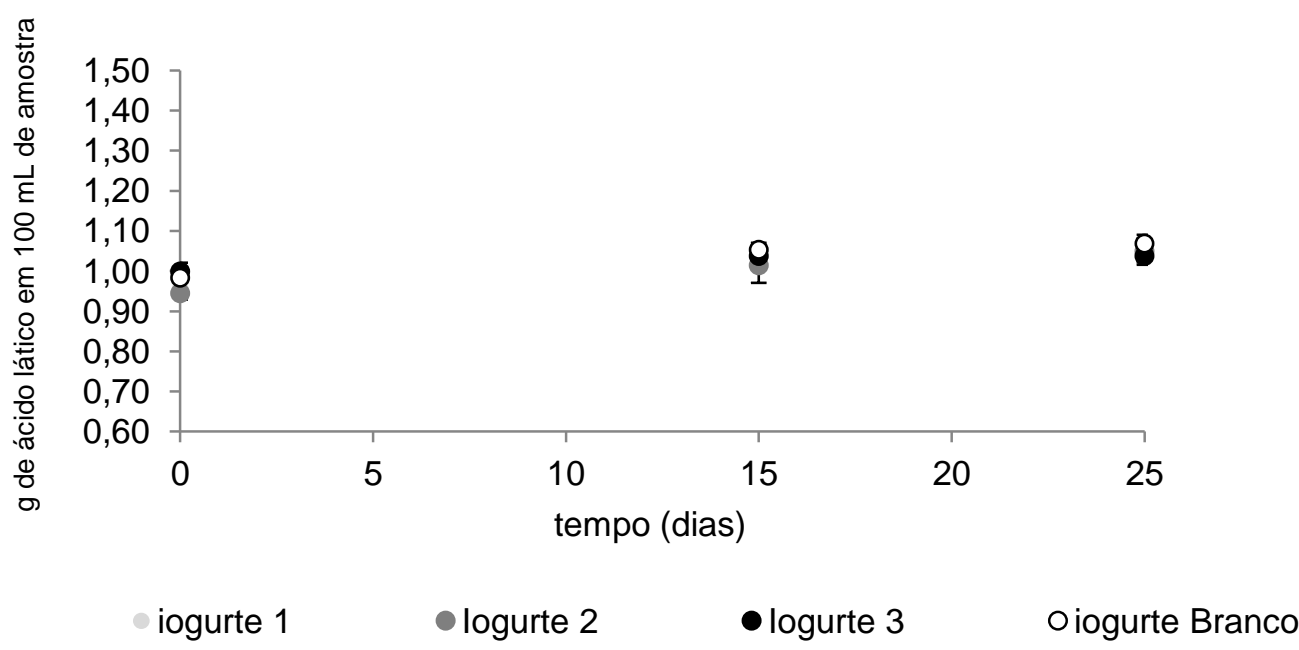

Figura 32. Valores de acidez titulável de amostras dos iogurtes produzidos, ao longo do tempo de armazenagem. 


\subsubsection{COLORIMETRIA INSTRUMENTAL}

Em relação aos parâmetros colorimétricos, seu comportamento é mostrado nas Figuras 33 e 34 .

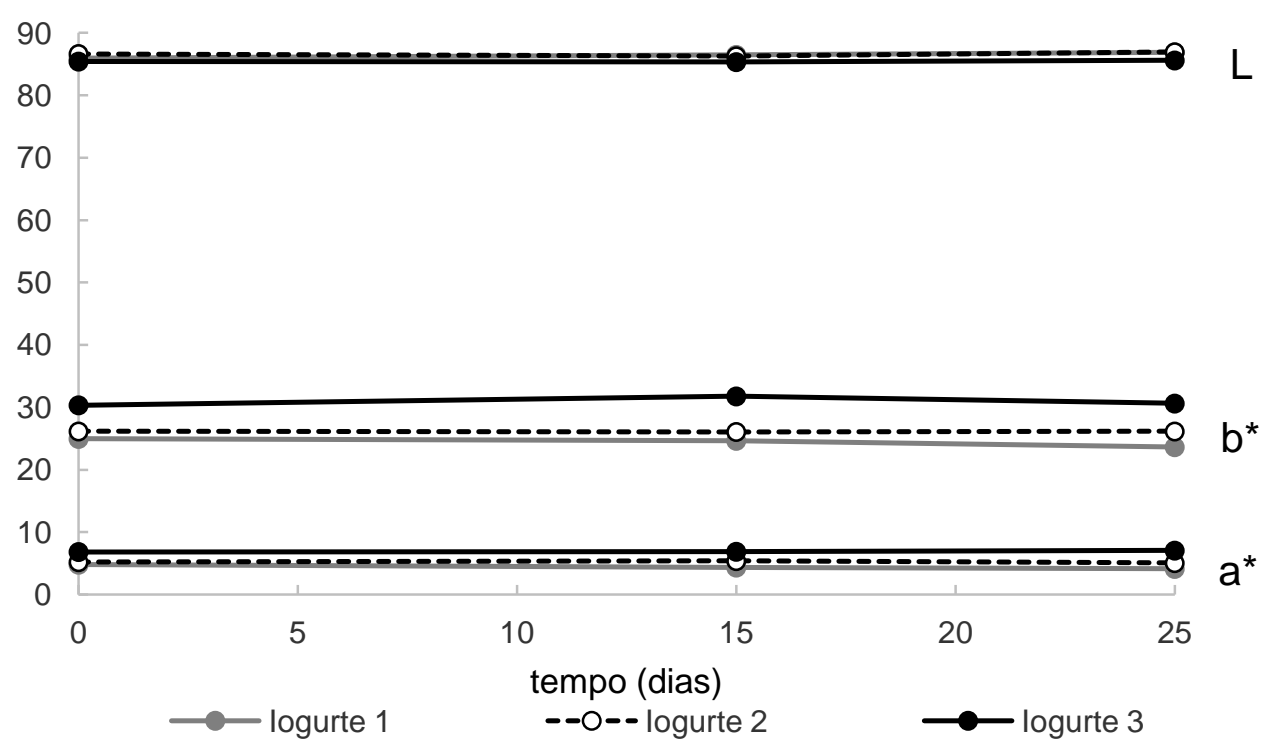

Figura 33. Parâmetros colorimétricos $L^{*}, a^{*}$ e $b^{*}$ obtidos para as amostras de iogurte produzidos, ao longo do tempo de armazenagem.

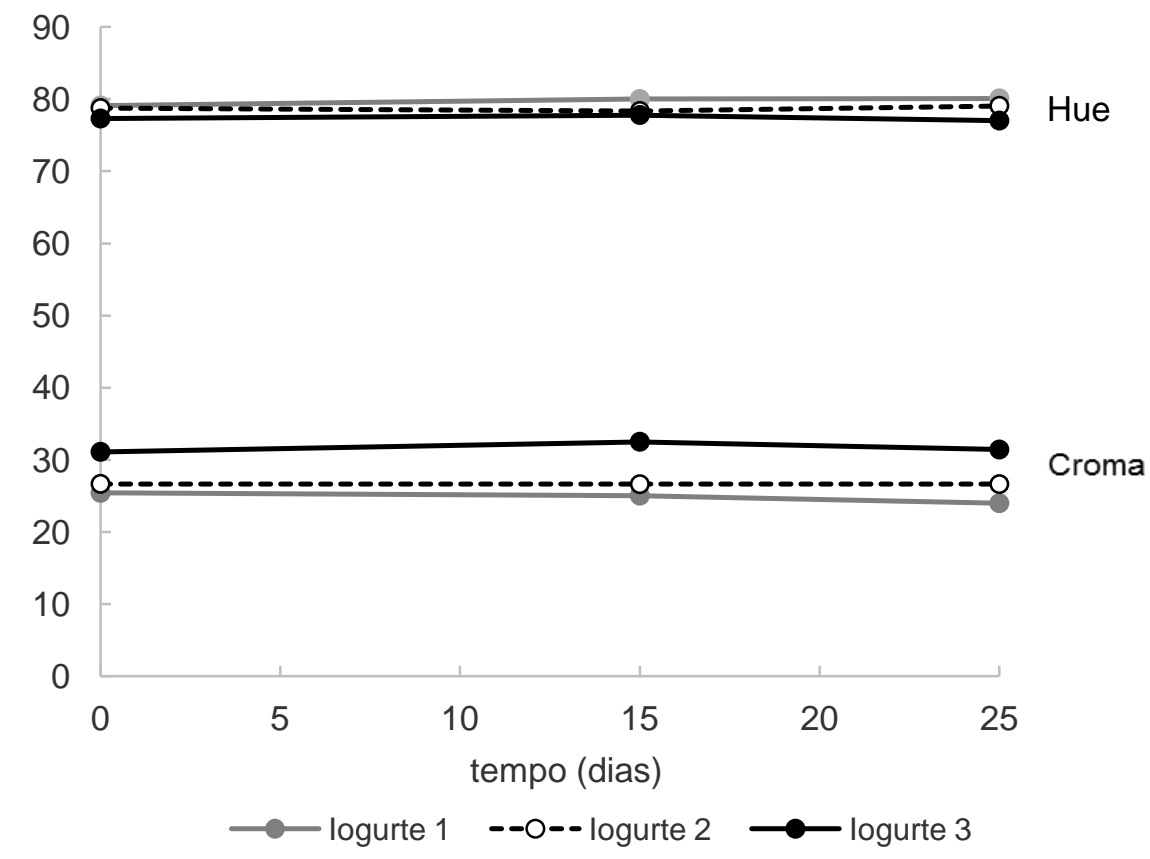

Figura 34. Valores dos parâmetros croma e ângulo de hue para as amostras de iogurte produzidos, ao longo do tempo de armazenagem. 
A diferença total de cor, por sua vez, é mostrada na Figura 35 para as três amostras de iogurtes contendo partículas lipídicas sólidas encapsulando beta-caroteno. É possível notar que no iogurte 1 , incorporado com as micropartículas lipídicas sem alfa-tocoferol, tal parâmetro se mostrou com valor maior e estatisticamente diferente dos apresentados para os iogurtes 2 e 3 .

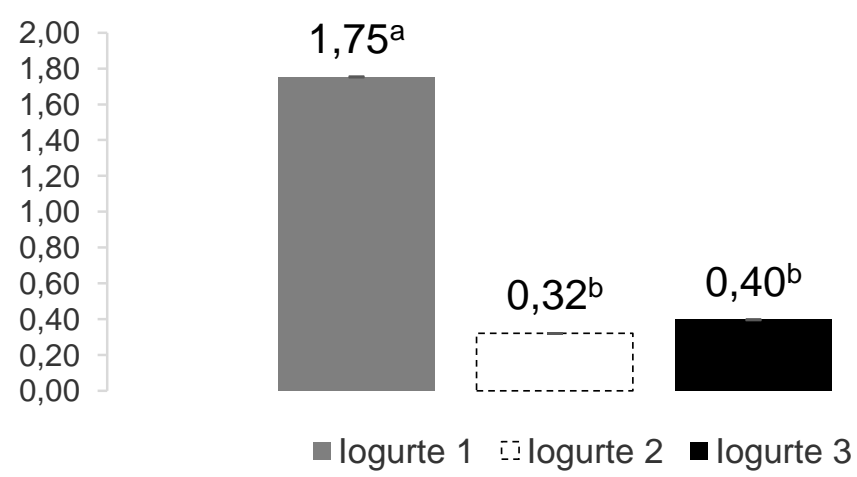

Figura 35. Diferença total de cor para as amostras de iogurte produzidos, ao longo do tempo de armazenagem.

Valores indicados com a mesma letra representam médias sem diferença significativa a 95\% de confiança.

Portanto, assim como nas dispersões de micropartículas, é possível inferir pelas análises de colorimetria instrumental que, também no iogurte, a presença do antioxidante se mostrou efetiva para a preservação do carotenoide encapsulado.

\subsubsection{DETERMINAÇÃO DOS PARÂMETROS REOLÓGICOS}

A qualidade do iogurte é de grande importância em sua aceitação, sendo que tal fato é influenciado em grande parte por sua consistência e viscosidade (MATHIAS et al., 2013). Deriva daí, então, a necessidade de se realizar estudos reológicos nos iogurtes produzidos, uma vez que a adição das dispersões de micropartículas lipídicas sólidas poderia ser prejudicial à textura do produto.

Em relação à caracterização reológica dos iogurtes produzidos, a análise dos reogramas nos revela um fluido pseudoplástico, isto é, fluido no qual a viscosidade aparente descresce com a taxa de deformação, típico do iogurte (MATHIAS et al., 2013; PURWANDARI et al., 2007) . Os resultados das curvas de fluxo foram ajustados ao modelo Herschel-Bulkley, conforme exposto na Figura 36. Os parâmetros que descrevem o modelo (tensão de cisalhamento inicial, índice de consistência e índice de comportamento do fluido), bem como o coeficiente de correlação do modelo estão apresentados na Tabela 14. 
(A)

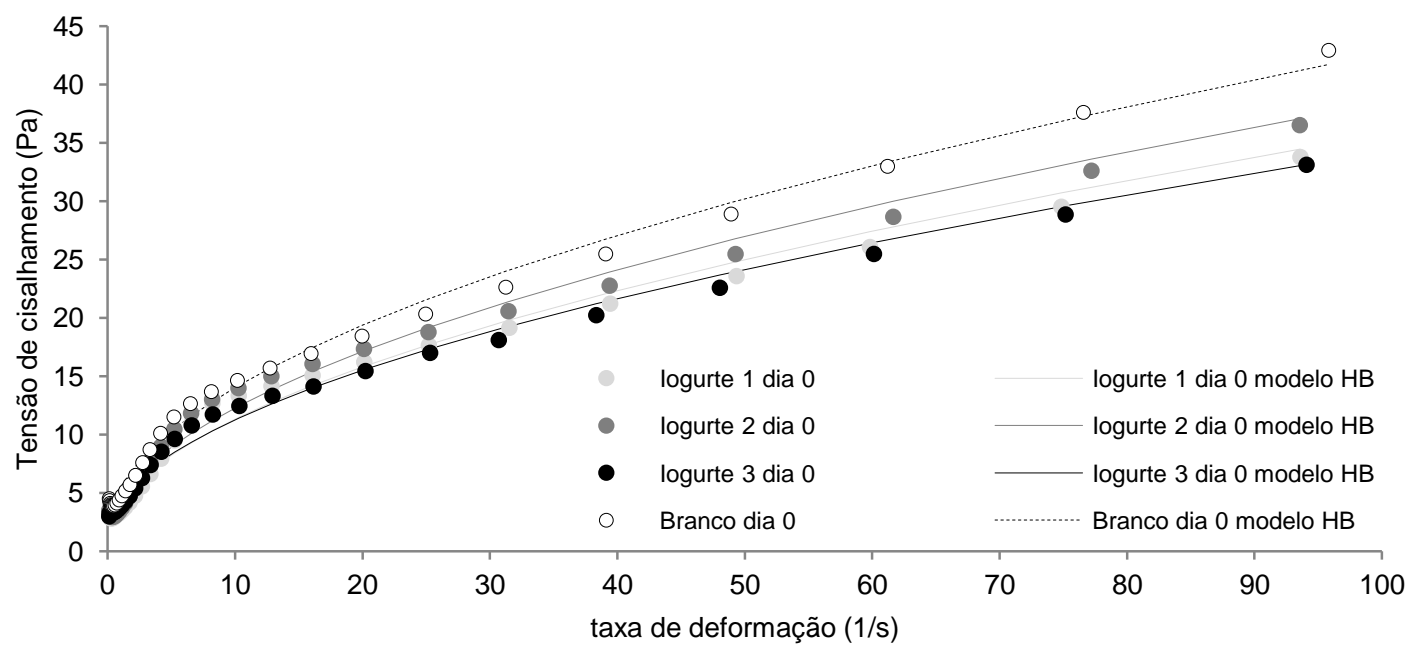

(B)
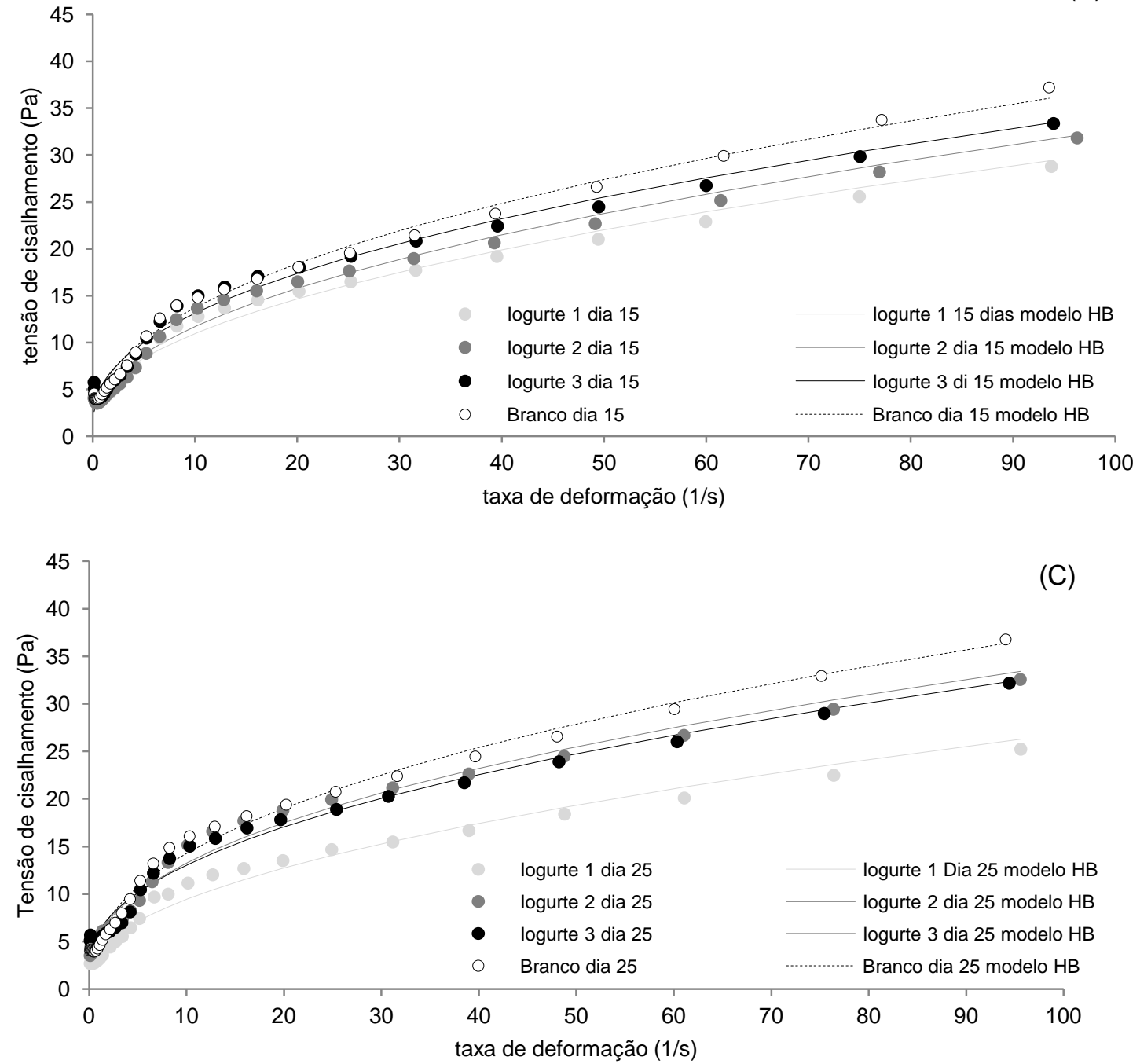

Figura 36. Curvas de fluxo para amostras de iogurtes - dia 0 (A), dia 15 (B) e dia 25 (C). 
Tabela 14. Parâmetros reológicos $\tau_{0}$ (tensão de cisalhamento inicial), $k$ (índice de consistência) e $n$ (índice de comportamento do fluido) obtidos.

\begin{tabular}{cccccc}
\hline & logurte & $\boldsymbol{\tau}_{\mathbf{0}}(\mathrm{Pa})$ & $\mathbf{k}\left(\mathbf{P a} . \mathbf{s}^{\mathrm{n}}\right)$ & $\mathbf{n}$ & $\begin{array}{c}\text { Coeficiente de } \\
\text { correlação }\end{array}$ \\
\hline \multirow{2}{*}{$\operatorname{dia}$} & 1 & $1,450^{\mathrm{a}} \pm 0,139$ & $2,771^{\mathrm{b}} \pm 0,168$ & $0,542^{\mathrm{c}} \pm 0,007$ & 0,952 \\
0 & 2 & $1,358^{\mathrm{a}} \pm 0,026$ & $3,336^{\mathrm{b}} \pm 0,155$ & $0,525^{\mathrm{c}, \mathrm{d}} \pm 0,007$ & 0,947 \\
& 3 & $1,543^{\mathrm{a}} \pm 0,260$ & $3,232^{\mathrm{b}} \pm 0,610$ & $0,522^{\mathrm{c}, \mathrm{d}} \pm 0,014$ & 0,972 \\
& Branco & $1,418^{\mathrm{a}} \pm 0,421$ & $4,056^{\mathrm{b}} \pm 0,513$ & $0,518^{\mathrm{c}, \mathrm{d}} \pm 0,006$ & 0,947 \\
\hline \multirow{2}{*}{$\operatorname{dia}$} & 1 & $1,680^{\mathrm{a}} \pm 0,543$ & $2,194^{\mathrm{b}} \pm 0,846$ & $0,501^{\mathrm{c}, \mathrm{d}} \pm 0,002$ & 0,905 \\
15 & 3 & $1,616^{\mathrm{a}} \pm 0,419$ & $3,679^{\mathrm{b}} \pm 0,499$ & $0,469^{\mathrm{c}, \mathrm{d}} \pm 0,024$ & 0,923 \\
& 3 & $1,430^{\mathrm{a}} \pm 0,338$ & $4,000^{\mathrm{b}} \pm 0,010$ & $0,451^{\mathrm{c}, \mathrm{d}} \pm 0,007$ & 0,895 \\
& Branco & $0,823^{\mathrm{a}} \pm 0,067$ & $4,729^{\mathrm{b}} \pm 0,255$ & $0,448^{\mathrm{c}, \mathrm{d}} \pm 0,004$ & 0,946 \\
\hline \multirow{2}{*}{ dia } & 1 & $1,255^{\mathrm{a}} \pm 0,631$ & $3,544^{\mathrm{b}} \pm 1,636$ & $0,469^{\mathrm{c}, \mathrm{d}} \pm 0,060$ & 0,943 \\
25 & 3 & $1,379^{\mathrm{a}} \pm 0,129$ & $4,084^{\mathrm{b}} \pm 0,413$ & $0,446^{\mathrm{c}, \mathrm{d}} \pm 0,013$ & 0,969 \\
& Branco & $1,926^{\mathrm{a}} \pm 0,599$ & $4,536^{\mathrm{b}} \pm 1,150$ & $0,433^{\mathrm{d}} \pm 0,036$ & 0,904 \\
& $1,619^{\mathrm{a}} \pm 0,841$ & $4,594^{\mathrm{b}} \pm 0,028$ & $0,446^{\mathrm{c}, \mathrm{d}} \pm 0,028$ & 0,945
\end{tabular}

Valores indicados com a mesma letra na mesma coluna representam médias sem diferença significativa a $95 \%$ de confiança.

Vários trabalhos podem ser encontrados na literatura versando sobre 0 comportamento reológico de iogurtes, e em muitos casos o modelo de Herschel-Bulkley é o que melhor se ajusta, sendo utilizado devido ao fato de contemplar em seu equacionamento um parâmetro extremamente importante para o processamento do iogurte, que é a tensão inicial de escoamento, ou $\tau_{0}$ (MATHIAS et al., 2013; STEFFE, 1996). De acordo com a modelagem realizada, é possível verificar que os valores de $n$, para todas as amostras e todos os tempos de armazenagem, se localizou abaixo de 1, confirmando o comportamento de fluido pseudoplástico. O valor de $\mathrm{k}$ (índice de consistência) foi maior para o iogurte branco, ou seja, a adição das dispersões de micropartículas lipídicas sólidas indica que houve uma mudança estrutural no iogurte, o que é compreensível uma vez que as dipersões são compostas por 95\% de água. Além disso, verifica-se que houve um ligeiro aumento nos valores deste mesmo parâmetro com o passar do tempo de armazenagem, para todos os iogurtes.

Além disso, foi analisada a viscosidade aparente das amostras para taxa de deformação fixa em $12 \mathrm{~s}^{-1}$. Ao longo do período estudado, não foi observada alteração na viscosidade aparente em nenhuma das amostras. Valores médios e desvios padrões das viscosidades aparentes podem ser vistos na Tabela 15. 
Tabela 15. Valores de viscosidade aparente de amostras dos iogurtes produzidos.

\begin{tabular}{ccccc}
\hline Dia & \multicolumn{4}{c}{ logurte } \\
\cline { 2 - 5 } & 1 & 2 & 3 & branco \\
$\mathbf{0}$ & $1,15^{\mathrm{a}} \pm 0,02$ & $1,26^{\mathrm{a}} \pm 0,04$ & $1,20^{\mathrm{a}} \pm 0,15$ & $1,30^{\mathrm{a}} \pm 0,02$ \\
$\mathbf{1 5}$ & $0,89^{\mathrm{a}} \pm 0,32$ & $1,26^{\mathrm{a}} \pm 0,09$ & $1,28^{\mathrm{a}} \pm 0,04$ & $1,33^{\mathrm{a}} \pm 0,05$ \\
$\mathbf{2 5}$ & $1,18^{\mathrm{a}} \pm 0,28$ & $1,32^{\mathrm{a}} \pm 0,05$ & $1,30^{\mathrm{a}} \pm 0,01$ & $1,40^{\mathrm{a}} \pm 0,003$
\end{tabular}

Valores indicados com a mesma letra na mesma coluna representam médias sem diferença significativa a 95\% de confiança.

Pela Tabela 15, pode-se verificar que os valores de viscosidade aparente a $12 \mathrm{~s}^{-1}$ não diferiram significativamente do iogurte branco para os iogurtes adicionados com micropartículas lipídicas sólidas.

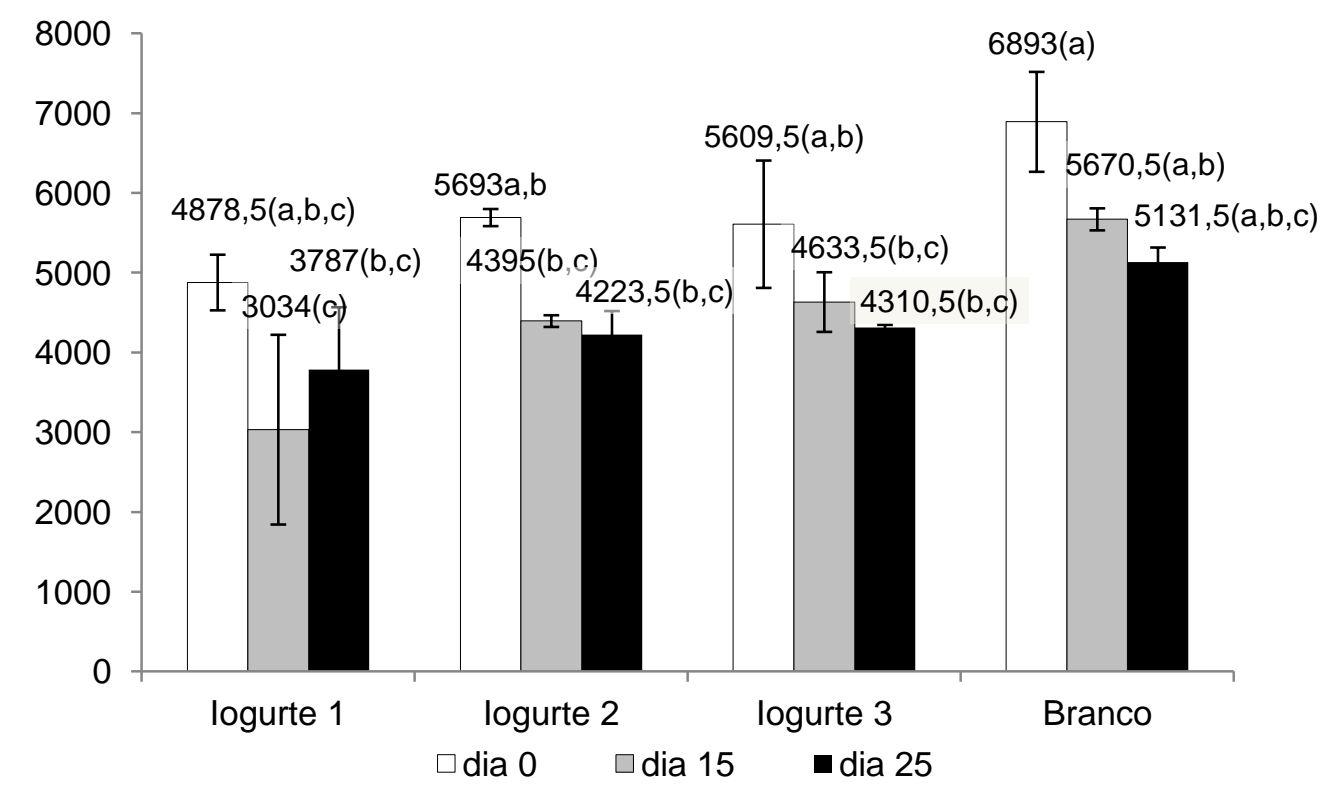

Figura 37. Valores de tixotropia dos iogurtes produzidos.

Valores indicados com a mesma letra representam médias sem diferença significativa a 95\% de confiança.

A Figura 37 ilustra os valores de tixotropia encontrados para as diferentes formulações de iogurtes produzidas. Nota-se decaimento da tixotropia ao longo do tempo para o iogurte branco, o qual se reproduziu nas tixotropias dos iogurtes adicionados das micropartículas lipídicas sólidas contendo beta-caroteno. Esses resultados confirmam que a adição destas MLS no iogurte não alteraram o comportamento reológico destas amostras em comparação ao iogurte branco. 


\subsubsection{AVALIAÇÃO SENSORIAL DOS IOGURTES}

As notas da avaliação de aceitação sensorial dos iogurtes aplicados foram analisadas de duas maneiras, intra e interamostral. $\mathrm{Na}$ análise intra-amostral, comparou-se cada um dos 4 atributos avaliados (cor, textura, sabor e aceitação global) de cada amostra, ao longo do tempo de estocagem. Na análise interamostral, comparou-se cada um dos 4 atributos das amostras entre si em um tempo fixo de observação. Desta forma, nas Tabelas 3, 4 e 5 estão os resultados obtidos na avaliação intra-amostral dos iogurtes 1,2 e 3, respectivamente. Na Figura 37 estão expostos os resultados da avaliação interamostral de cor, textura, sabor e aceitação global, respectivamente.

Em ambas as análises realizadas, a diferença entre as médias obtidas não foi estatisticamente significativa, resultando em uma nota média geral de 7,4 para aceitação dentro de uma escala de 1 a 9 pontos.

(a) Cor

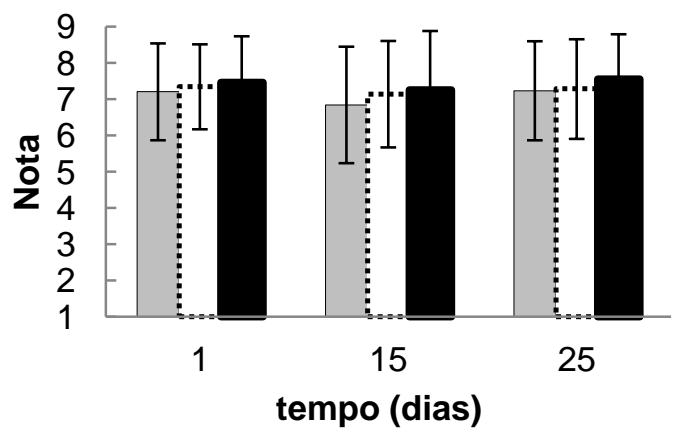

$\square$ logurte 1 logurte 2 Dlogurte 3

(c) Sabor

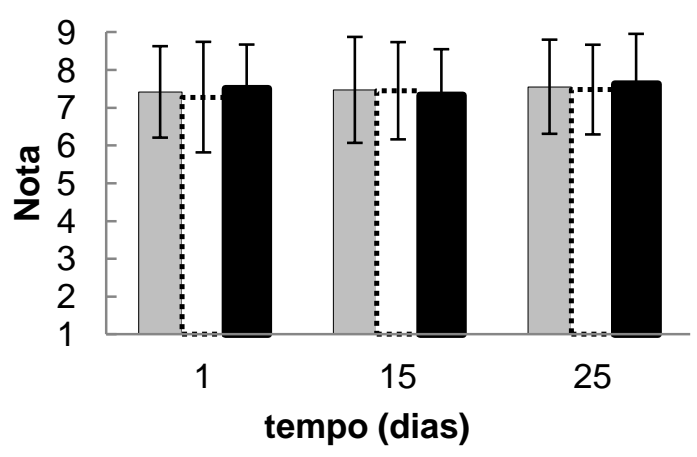

$\square$ logurte $1 \quad:$ logurte $2 \quad$ alogurte 3 (b) Textura

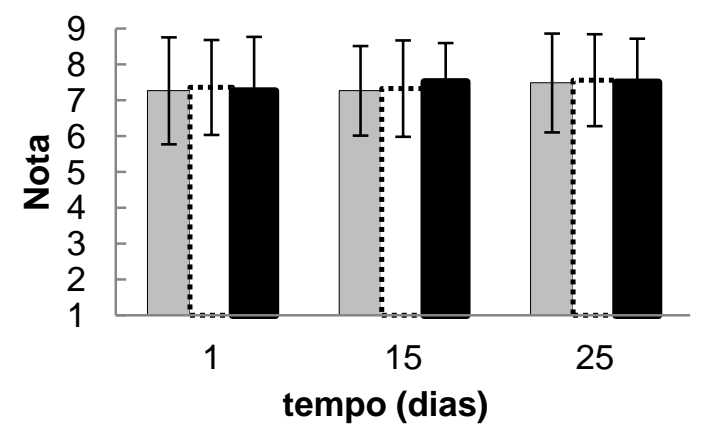

$\square$ logurte $1 \quad$ :logurte 2 alogurte 3

(d) Aceitação Global

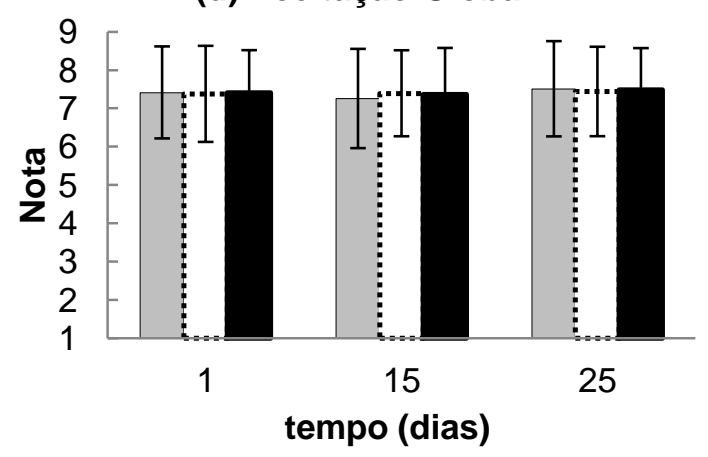

$\square$ logurte $1 \quad \%$ logurte 2 logurte 3

Figura 38. Notas atribuídas para os diferentes atributos avaliados na análise sensorial dos iogurtes produzidos com micropartículas lipídicas sólidas encapsulando beta-caroteno : (a) cor; (b) textura; (c) sabor; (d) aceitação global. 
Tal resultado pode ser considerado extremamente satisfatório, pois significa que os provadores, em média, disseram que o iogurte adicionado com as micropartículas lipídicas sólidas encapsulando beta-caroteno foi um produto do qual "gostaram regularmente" a "gostaram muito", ou seja, o produto foi aprovado do ponto de vista sensorial. A adição de dispersões de micropartículas lipídicas sólidas não provocou reações desagradáveis em relação à textura do produto, que era o maior receio neste trabalho de Mestrado. 


\section{CONCLUSÕES}

Os dados obtidos e apresentados nesta dissertação de Mestrado permitem concluir que:

- É possível solubilizar o isolado proteico de soja utilizado neste trabalho através de um processo alcalino-térmico, a $85^{\circ} \mathrm{C}$ por 30 minutos e $\mathrm{pH} 12$;

- É possível emulsificar estearina de palma utilizando-se o isolado proteico de soja solubilizado, e produzir partículas lipídicas sólidas encapsulando beta-caroteno. Tais micropartículas se mostraram estáveis ao longo do tempo de armazenagem, tanto em relação do seu diâmetro médio quanto em relação ao potencial zeta. Mostraram diferentes capacidades de proteção do beta-caroteno encapsulado contra degradação, e tal capacidade foi altamente dependente da presença de alfa-tocoferol na formulação;

- É possível incorporar as dispersões de micropartículas lipídicas sólidas encapsulando beta-caroteno em iogurtes, produzindo-os no sabor laranja, cenoura e mel, com parâmetros colorimétricos e textura parecidos com os similares comercialmente disponíveis;

- Os iogurtes produzidos foram muito bem aceitos na análise sensorial, indicando que a adição das micropartículas foi bem sucedida, e essa aceitação se manteve estável ao longo dos 25 dias de estocagem. 


\section{SUGESTÕES PARA TRABALHOS FUTUROS}

Para a continuação deste trabalho de pesquisa sugere-se alguns tópicos:

- Analisar a possível ação protetora da proteína de soja na interface em diferentes condições de stress;

- Investigar a possibilidade de aumento da estabilidade dos sistemas ao longo do tempo, propriedade requerida dependendo da aplicação final a que o sistema será destinado.

- Avaliar a possibilidade de produção de sistemas com maior poder encapsulante, visando aplicação em produtos alimentícios nos quais essa característica é requerida.

- Testar aplicabilidade das formulações de micropartículas lipídicas sólidas encapsulando beta-caroteno em outros produtos alimentícios. 


\section{REFERÊNCIAS BIBLIOGRÁFICAS}

AGROPALMA (2014). Website da empresa, catálogo de produtos. Disponível em: $<$ http://www.agropalma.com.br/produtos.asp $>$ Acesso em: 09 set. 2014.

ASSOCIATION OF OFFICIAL ANALYTICAL CHEMISTS - AOAC. Official methods of analysis of the Association of Official Analytical Chemists. Washington, DC: AOAC, 1997.

AWAD, T. S. et al. A critical study of novel physically structured lipid matrices composed of homolipid from Capra hircus and theobroma oil. International Journal of Pharmaceutics, Amstedam, v. 322, p. 67-78, 2006.

AWAD, T.S. et al. Effect of Omega-3 Fatty Acids on Crystallization, Polymorphic Transformation and Stability of Tripalmitin Solid Lipid Nanoparticle Suspensions. Crystal Growth and Design, Washington, v. 9, p. 3405-3411, 2009.

BARAC, M. et al. Soy protein modification - A review. Acta Periodica Technologica University of Novi Sad, Serbia, Vol 35, p. 3 -16. 2004.

BERTRAM, J.S.; VINE, A.L.; Cancer prevention by retinoids and carotenoids: Independent action on a common target. Biochimica et Biophysica Acta, Amsterdam ,v. 1740, p. 170178. 2005.

BIODIESELBR. Apresenta dados, notícias e revista de acesso eletrônico na área de biodiesel. Curitiba. Disponível em: <http://www.biodieselbr.com/plantas/palma/palma.htm> Acesso em: 09 set. 2014.

BLIGH, E.G.; DYER,W.J. 1959. A rapid method for total lipid extraction and purification. Canadian Journal of Biochemistry and Physiology, Ottawa, v. 37, p. 911-917, 1959.

BRASIL. Ministério da Agricultura, Pecuária e Abastecimento. Secretaria de Defesa Agropecuária. Padrões de Identidade e Qualidade de Leites Fermentados. Instrução Normativa n. 46 de 23 de outubro de 2007. Diário Oficial da União, Brasília, 2007. 
BRASIL. Ministério da Agricultura, Pecuária e Abastecimento. Notícias: crescimento da renda aumenta demanda por alimentos no Brasil. 2013. Disponível em:

http://www.agricultura.gov.br/comunicacao/noticias/2013/10/crescimento-da-renda-aumentademanda-por-alimentos-no-brasil. Acesso em: 21 set. 2014.

COORNACHIA, L; ROOS, Y.H. Stability of $\beta$-carotene in protein-stabilized oil-in-water delivery systems. Journal of Agricultural and Food Chemistry, Washington, v. 59, p. 7013-7020, 2011a.

CORNACCHIA, L.; ROOS, Y.H. State of dispersed lipid carrier and interface composition as determinants of beta-carotene stability in oil-in-water emulsions. Journal of Food Science, Hoboken, v. 76, p. C1211-C1218, 2011 b.

CONN, P.F., SCHALCH, W. , TRUSTCOT, T.G.The singlet oxygen and carotenoid interaction. V Journal. Photochemistry and Photobiology B: Biology, Lausanne, v. 2, p. 41-47. 1991.

DAMODARAN, S.; PARKIN, K. L.; FENNEMA, O. R.. Química de Alimentos de Fennema. 4. ed. Porto Alegre: Artmed, 2010. 900 p.

DAHAN, A.; HOFFMAN, A. Rationalizing the selection of oral lipid based drug delivery systems by na in vitro dynamic lipolysis model for improved oral bioavailability of poorly water soluble drugs. Journal of Controlled Release, Amsterdam, v. 129, p. 1-10, 2008.

DEMAN, J. M. Principles of Food Chemistry. 3. ed. New York: Springer, 1999. 520 p.

DESAI, K.G.H.; PARK, J.H. Recent developments in microencapsulation of food ingredients. Drying Technology, New York, v. 23, p. 1361-1394, 2005.

DE VOS, P. et al. Encapsulation for preservation of functionality and targeted delivery of bioactive food components (Review). International Dairy Journal, Amsterdam, v. 20, p. 292 $-302,2010$.

DEWETTINCK, K.; HUYGHEBAERT, A. Fluidized bed coating in food technology. Trends In Food Science and Technology, Kidlington, v. 10, p.163-168, 1999. 
DINIZ, A.C.P. Geleificação a frio de isolados protéicos de soja. 2007. 170f. Tese (Doutorado) - Faculdade de Engenharia de Alimentos, Universidade Estadual de Campinas, Campinas, 2007.

EDGE, R., MCGARVEY, D.J., TRUSCOTT, T.G. The carotenoids as anti-oxidants - a review. Journal of Photochemistry and Photobiology B: Biology, Lausanne, v. 41, p.189-200. 1997.

FOEGEDING, E. A.; DAVIS, J. P. Food protein functionality: A comprehensive approach. Food Hydrocolloids, Amsterdam , v. 25, p.1853-1864, 2011.

GOKCE, E.H.; KORKMAZ, E.; DELLERA, E.; SANDRI, G.; BONFERONE, M.C.; OZER, O. Resveratrol-loaded solid lipid nanoparticles versus nanostructured lipid carriers: evaluation of antioxidant potential for dermal applications. International Journal of Nanomedicine, Auckland, v. 7, p. 1841-1850, 2012a.

GOKCE, E.H.; KORKMAZ, E.; DELLERA, E.; SANDRI, G.; BONFERONE, M.C.; OZER, O. A comparative evaluation of coenzyme Q10-loaded liposomes and solid lipid nanoparticles as dermal antioxidant carriers. International Journal of Nanomedicine, Auckland v. 7, p. 5109-5117, 2012b.

FRASER, PD; E BRAMLEY, PM. The biosynthesis and nutritional uses of carotenoids (Review), Progress in Lipid Research, Kidlington, v. 43, p. 228-265, 2004.

GOMES, G. V. L. et al. Characterization and shelf life of beta-carotene-loaded solid lipid microparticles produced with stearic acid and sunflower oil. Brazilian Archives of Biology and Technology (Impresso), Curitiba, v. 56, p. 663-671, 2013.

GOMES, G. V. L. et al. Developmnent of a lipid particle for beta-carotene encapsulation using a blend of tristearin and sunflower oil: choice of the lipid matrix and evaluation of the shelf life of dispersions. Food Technology and Biotechnology, Zagreb, v. 51, p. 383-391, 2013.

GONNET, M.; LETHUAUT, L.; BOURY, F. New trends in encapsulation of liposoluble vitamins. Journal of Controlled Release, Amsterdam , v. 146, p.276-290, 2010. 
GOUIN, S. Microencapsulation: industrial appraisal of existing Technologies and trends. Trends in Food Science \& Technology, Cambridge, v. 15, p.330-347, 2004.

GUTIERRES, V. O. et al. Curcumin-supplemented yoghurt improves physiological and biochemical markers of experimental diabetes. British Journal of Nutrition, Cambridge, v. 108, p. 440-448, 2012.

HAYAKAWA, S.; NAKAI, S. Relationships of hydrophobicity and net charge to the solubility of milk and soy proteins. Journal of Food Science, Chicago, v. 50, 486-491, 1985.

HEKMAT, S.; REID, G. Sensory properties of probiotic yogurt is comparable to standard yogurt. Nutrition Research, New York, v. 26, p. 163-166, 2006.

HELGASON, T. et al. Impact of surfactant properties on oxidative stability of $\beta$-carotene encapsulated within solid lipid nanoparticles. Journal of Agriculture and Food Chemistry, Washington, v. 57, p. 8033-8040, 2009.

HENTSCHEL, A.; GRAMDORF, S.; MÜLLER, R.H.. $\beta$-Carotene-Loaded Nanostructured Lipid Carriers. Nanoscale Food Science, Engineering, And Technology, Hoboken , v. 73, n. 2, p.1-6, 2008.

HUGHES, D. A.; WRIGHT, A. J.; FINGLAS, P. M. The effect of beta-carotene supplementation on the immune function of blood monocytes from healthy male nonsmokers. Journal of Laboratory and Clinical Medicine, Philadelphia, v. 129, n. 3, p.309-317, 1997.

HUNG, L. C. et al. An improved method for the preparations of nanostructured lipid carriers containing heat-sensitive bioactives. Colloids and Surfaces B: Biointerfaces, Amsterdam, v. 87, p. 180-186, 2011.

INSTITUTO ADOLFO LUTZ. Métodos físico-químicos para análise de alimentos. Versão eletrônica. 1020f. São Paulo. 2008.

JEONG, S. H.; PARK, J. H.; PARK, K.. Formulation issues around lipid-based oral and parenteral delivery systems. In: WASSAN, K. M. Role of Lipid Excipients in Modifying 
Oral and Parenteral Drug Delivery: Basic Principles and Biological Examples. Hoboken: Wiley, 2007. Cap. 2. p. 32-43.

KALUSTIAN, P. Pharmaceutical and cosmetic uses of palm and lauric products. JAOCS, Heidelberg, v. 62, n. 2, p. $431-433,1985$.

KINSELLA, J.E. Functional properties of soy proteins. JAOCS, Heidelberg, v. 56, 242-258. 1979.

KRZEMINSKI, A.; GROSSHABLE, K.; HINRICHS, J. Structural properties of stirred yoghurt as influenced by whey proteins. LWT - Food Science and Technology, London, v. 44, p. $2134-2140,2011$.

KRIMM, S.; BANDEKAR, J. Vibrational spectroscopy and conformation of peptides, polypeptides and proteins. Advances in Protein Chemistry, Maryland Heights, v. 38, p. 184-364.

LACATUSU, I. et al. Highly antioxidant carotene-lipid nanocarriers: synthesis and antibacterial activity. Journal of Nanoparticle Research, Dordrecht, v. 14, p. 902-917, 2012.

LAEMMLI, U.K. Cleavage of structural proteins during de assembly of the head of bacteriofage T4. Nature, London, v. 227 , 680-185, 1970.

LAI, F. et al. Artemisia arborescens L. essential oil-loaded solid lipid nanoparticles for potential agricultural application: preparation and characterization. AAPS Pharmaceutics, New York v. 7, p. E1-E9, 2006.

$\mathrm{LI}, \mathrm{H}$. et al. Enhancement of gastrointestinal absorption of quercetin by solid lipid nanoparticles. Journal of Controlled Release, Amsterdam, v. 133, p. 238-244, 2009.

LIU, C.H.; WU, C.T. Optimization of nanostructured lipid carriers for lutein delivery. Colloids and Surfaces A: Physicochemical and Engineering Aspects, Amsterdam, v. 353, p. 149156, 2010.

LOLLO, P. C. B. et al. Probiotic yogurt offers higher immune-protection than probiotic 
whey beverage. Food Research International, Kidlington, v. 54, p. 118-224, 2013.

LOURENS-HATTING, A.; VILJOEN, B.C. Yogurt as probiotic carrier food (Review). International Dairy Journal, Amsterdam, v. 11, p. 1-17, 2001

MALAKI-NIK, A.; LANGMAID, S.; WRIGTH, A.J. Non-ionic surfactant and interfacial structure impact crystallinity and stability of $\beta$-carotene loaded lipid nanodispersions. Journal of Agricultural and Food Chemistry, Washington, v. 60, p. 4126-4135, 2012.

MANTSCH, H.H.; CHAPMAN, D. Infrared absorption of biomolecules. Nova York: Wiley Liss. 1996

MATHIAS, T. R. S. et al. Avaliação do comportamento reológico de diferentes iogurtes comerciais. Brazilian Journal of Food Technology, Campinas, v. 16, n.1, p. 12-20, 2013.

MCCLEMENTS D.J. Food emulsions: principles, practice, and techniques. Washington: CRC Press, 2005.

MCCLEMENTS D.J. Food emulsions: principles, practice, and techniques. $2^{\underline{a}}$ ed. Washington: CRC Press, 2004.

McCLEMENTS, D.J.; DECKER, E.A.; PARK, Y. Controlling Lipid Bioavailability through Physicochemical and Structural Approaches. Critical Reviews in Food Science and Nutrition, Boca Raton, v.49, p. 48-67, 2009.

McCLEMENTS, D. J.; LI, Y. Structured emulsion-based delivery systems: Controlling the digestion and release of lipophilic food components: -. Advances in Colloid and Interface Science, Amsterdam, v. 159, p.213-228, 2010.

McCLEMENTS, D. J. Crystals and crystallization in oil-in-water emulsions: implications for emulsion-based delivery systems. Advances in Colloid and Interface Science, Amsterdam, v. 174, p.1-30, 2012.

MEHNERT, W.; MADER, K. Solid lipid nanoparticles Production, characterization and applications. Advanced Drug Delivery Reviews, Amsterdam , v. 47, p.165-196, 2001. 
MEDEIROS,A.C.L. logurte caprino probiótico em pó: estudo do processo de secagem da caracterização do pó e da viabilidade do probiótico. 2013. 72 f. Dissertação (Mestrado) - Faculdade de Zootecnia e Engenharia de Alimentos, Universidade de São Paulo, Pirassununga, 2013.

MEILGAARD, M.C.; CIVILLE, G.V.; CARR, B.T. Sensory Evaluation Techniques. CRC Press, Boca Raton, EUA, $2^{\text {a }}$ ed., 464 p, 1991.

MOHAN, S.; PUVIARASAN, N.; BAKKIALAKSHMI, S. Vibrational spectra and analysis of tryptophan. Asian Journal of Chemistry, Ghaziabad, v.11, n.4, p. 1137-1143, 1999.

MÜLLER, R.H.; MADER, K.; GOHLA, S. Solid lipid nanoparticles (SLN) for controlled drug delivery: a review of the state of the art. European Journal of Pharmaceutics and Biopharmaceutics, Londres, v.50, p. 161-177, 2000.

MÜLLER, R.H.; RADTKE, M.; WISSING, S.A. Solid lipid nanoparticles (SLN) and nanostructured lipid carriers (NLC) in cosmetic and dermatological preparations. Advanced Drug Delivery Reviews, Amsterdam, v. 54, n. 1, p. S131-S155, 2002.

NEDOVIC, V.; KALUSEVIC, A.; MANOJLOVIC, V. An overview of encapsulation technologies for food applications. Procedia Food Science, Amsterdam, v. 1, n. 1, p.18061815, 2011.International Congress on Engineering and Food 11nd 2011.

OKURO, P. K.; MATOS JUNIOR, F. E.; FAVARO-TRINDADE, C. S. Technological Challenges for Spray Chilling Encapsulation of Functional Food Ingredients. Food Technology Biotechnology, Zagreb, v. 51, n. 2, p.171-182, 2013.

OLLILAINEN, V.; HEINONEN, M.; LINKOLA, E. Caroteinoids and retinoids in finnish foods: meat and meat products. Journal of Food Composition and Analysis, Maryland Heights, p. 178-188. 1988.

PATEL, H. M.; RYMAN, Brenda E.. ORAL ADMINISTRATION OF INSULIN BY ENCAPSULATION WITHIN LIPOSOMES. Febs Letters, Amsterdam, v. 62, n. 1, p.60-63, 1976. 
PATEL, M.R.; SAN MARTIN-GONZALEZ, M.F. Characterization of ergocalciferol loaded solid lipid nanoparticle. Journal of Food Science, Hoboken, v. 71, p. N8-N13, 2012.

PALACE, V.P.; KHAPER, N.; QIN Q.; SINGAL, P.K. Antioxidant potentials of vitamin A and carotenoids and their relevance to heart desease. Free Radical Biology \& Medicine, Philadelphia, v. 26, p. 746-761, 1999.

PETERSON, G.L. Review of the folin phenol protein quantification method of Lowry, Rosebrough, Farr and Randall. Analytical Biochemistry, Philadelphia, v. 100, p. 201-219, 1979.

POOL, H.; MENDOZA, S.; XIAO, H.; MCCLEMENTS, D.J. Encapsulation and release of hydrophobic bioactive components in nanoemulsion-based delivery systems: impact of physical form on quercetin bioaccessibility. Food \& Function, Cambridge, v. 4, p. 162-174, 2013.

PORTER, C. J. H.; TREVASKIS, N. L.; CHARMAN, W. N. Lipids and lipid-based formulations: optimizing the oral delivery of lipophilic drugs. Nature Reviews: Drug Discovery, London, v. 6, n. 3, p.231-248, Mar. 2007.

PRIVALOV, P.L.; KHECHINASHVILI, N.N. A thermodynamic approach to the problem of stabilization of globular protein structure: a calorimetric study. Journal of Molecular Biology, London, v. 86, p. 665-684, 1974.

PROMBUTARA, P.; KULWATTHANASAL, Y.; SUPAKA, N.; SRAMALA, I.; CHAREONPORNWATTANA, S. Production of nisin-loaded solid lipid nanoparticles for sustained antimicrobial activity. Food Control, Kidlington v. 24, p.184-190, 2012.

PURWANDARI, U.; SHAH, N.P.; VASILJEVIC, T. Effects of exopolysaccharide-producing strains of Streptococccus thermophiles on technological and rheological properties of settype yoghurt. International Dairy Science, New York, v. 17, p. 1344-1352, 2007.

QI, C.; CHEN, Y.; HUANG, J.H.; JINA, Q.Z.; WANGA, X.G. Preparation and characterization of catalase-loaded solid lipid nanoparticles based on soybean phosphatidylcholine. Journal of the Science of Food and Agriculture, Chichester, v. 92, p. 787-793, 2012. 
RÉ, M.I. Microencapsulation by Spray Drying. Drying Technology, New York, v. 16, n.6, p. 1195-1236, 1998.

RELKIN, P.; YUNG, J.; KALNIN, D.. Structural Behaviour of Lipid Droplets in Proteinstabilized Nano-emulsions and Stability of $\alpha$-Tocopherol. Food Biophysics, New York, v. 3, p.163-168, 2008.

ROBINSON, R.K.; LUCEY, J.A.; TAMIME, A.Y. Manufacture of yoghurt. In: TAMIME, A.Y. (Ed.). Fermented milks. Oxford: Blackwell Science, 2006, cap. 3, p. 53-75.

SANTIAGO, L. G.; MALDONADO-VALDERRAMA, J.; MARTÍN-MOLINA, A. Adsorption of soy protein isolate at air-water and oil-water interfaces. Colloids and Surfaces A: Physicochemical and Engineering Aspects, Amsterdam, v. -, n. 323, p.155-162, 2008.

SCALIA, S.; MEZZENA, M. Incorporation of quercetin in lipid microparticles: Effect on photoand chemical-stability. Journal of Pharmaceutical and Biomedical Analysis, Amsterdam, v. 49, p. 90-94, 2009.

SHUKAT, R.; RELKIN, P. Lipid nanoparticles as vitamin matrix carriers in liquid food systems: on the role of high-pressure homogenisation, droplet size and adsorbed materials.

Colloids and Surfaces B: Biointerfaces, Amsterdam, v. 86, p. 119-124, 2011.

SHUKAT, R.; BOURGAUX, C.; RELKIN, P. Crystallisation behaviour of palm oil nanoemulsions carrying vitamin E. Journal of Thermal Analysis and Calorimetry, Budapest, v. 108, p. 153-161, 2012.

SIGMA-ALDRICH. Website da empresa, catálogo de produtos. 2014. Disponível em: $<$ http://www.sigmaaldrich.com/catalog/product/sigma/10417?lang=pt\&region=BR $>$ Acesso em: 21 ago. 2014.

SILVA, J. C. Estabilidade físico-química e avaliação de digestibilidade in vitro de micropartículas lipídicas sólidas produzidas com óleo de palmiste. 2013. $86 \mathrm{f}$. Dissertação (Mestrado). - Faculdade de Zootecnia e Engenharia de Alimentos, Universidade de São Paulo, Pirassununga, 2013.

SILVA, J. et al. Characterization, physicochemical stability, and evaluation of in vitro 
digestibility of solid lipid microparticles produced with palm kernel oil and tristearin. Food Science and Technology. Campinas. (aceito para publicação).

SIONKOWSKA, A. et al. Chemical and thermal cross-linking of collagen and elastin hydrolysates. International Journal of Biological Macromolecules, Amsterdam, v. 47, p. 570-577, 2010.

SORGENTINI, D. A.; WAGNER, J. R.; AÑÓN, M. C.. Effects of Thermal Treatment of Soy Protein Isolate on the Characteristics and Structure-Function Relationship of Soluble and Insoluble Fractions. Journal of Agriculture and Food Chemistry, Amsterdam, v. 43, n. 9, p.2471-2479, 1995.

SOUTO, E.B.; MULLER, R.H. The use of SLN and NLC as topical particulate carriers for imidazole antifungal agents. Pharmazie, Eschborn, v. 61, n. 5, p. 431-437, 2006.

STEFFE, J.F. Rheological methods in food process engineering. 2a ed., Freeman Press: Michigan, 1996.

TAKEITI, C.Y.Influência do tratamento térmico nas propriedades funcionais de isolados protéicos de soja e de seus hidrolisados enzimáticos. Dissertação (Mestrado), Faculdade de Engenharia de Alimentos, Universidade Estadual de Campinas, Campinas, 2002.

TAMIME, A.Y.; ROBINSON, R.K.Yoghurt science and technology. 2a ed. Boca Raton: CRC, 2004. $619 \mathrm{p}$.

TIKEKAR, R.V.; NITIN, N.. Distribution of Encapsulated Materials in Colloidal Particles and Its Impact on Oxidative Stability of Encapsulated Materials. Langmuir, Washington, v. 28, p. 9233-9243, 2012.

TONIAZZO, T. et al. Beta-carotene-loaded liposome dispersions stabilized with xanthan and guar gums: physico-chemical stability and feasibility of application in yogurt. LWT- Food Science and Technology, London, v. 59, p. 1265-1273, 2014. 
TONON, R.; BRABET, C.; HUBINGER, M.D.. Influence of process conditions on the physicochemical properties of acai (Euterpe oleraceae Mart.) powder produced by spray drying. Journal of Food Engineering, London, v. 88, p. 411-418, 2008.

TRIPPLET II, M.D.; RATHMAN, J.F. Optimization of $b$-carotene loaded solid lipid nanoparticles preparation using a high shear homogenization technique. Journal of Nanoparticle Research, Dordrecht, v. 11, p. 601-614, 2009.

TROMBINO, S.; CASSANO, R.; MUZZALUPO, R.; PINGITORE, A.; CIONE, E.; PICCI, N. Stearyl ferulate-based solid lipid nanoparticles for the encapsulation and stabilization of $\beta$ carotene and $\alpha$-tocopherol. Colloids and Surfaces B: Biointerfaces, Amsterdam, v. 72, p. 181-187, 2009.

WHITE J. A., HART R. J., FRY J. C. An evaluation of the waters Pico-Tag system for the amino-acid-analysis of food materials. Journal of Automatic Chemistry, New York, $\mathrm{n}^{\circ} 8$, v.4, p. 170-177, 1986.

YAP, P.H.; deMAN, J.M.; deMAN, L. Polimorphism of palm oil and palm oil products. JAOCS, Heidelberg, n.5, v. 66, p.693-697, 1989

ZHENG, M. et al. Formulation and characterization of nanostructured lipid carriers containing a mixed lipids core. Colloids and Surfaces A: Physicochemical and Engineering Aspects, Amsterdam, v. 430, p. 76 - 84, 2013.

ZUIDAM, N. J.; SHIMONI, E. Overview of Microencapsulation for Use in Food Products and Methods to Make Them. In: ZUIDAM, N. J.; NEDOVIC, V. Encapsulation Technologies for Active Ingredients and Food Processing. London: Springer, 2010. Cap. 2. p. 3-29. 


\section{ANEXO 1 - MODELO DE CURVA ANALÍSTICA PARA QUANTIFICAÇÃO PROTEICA}

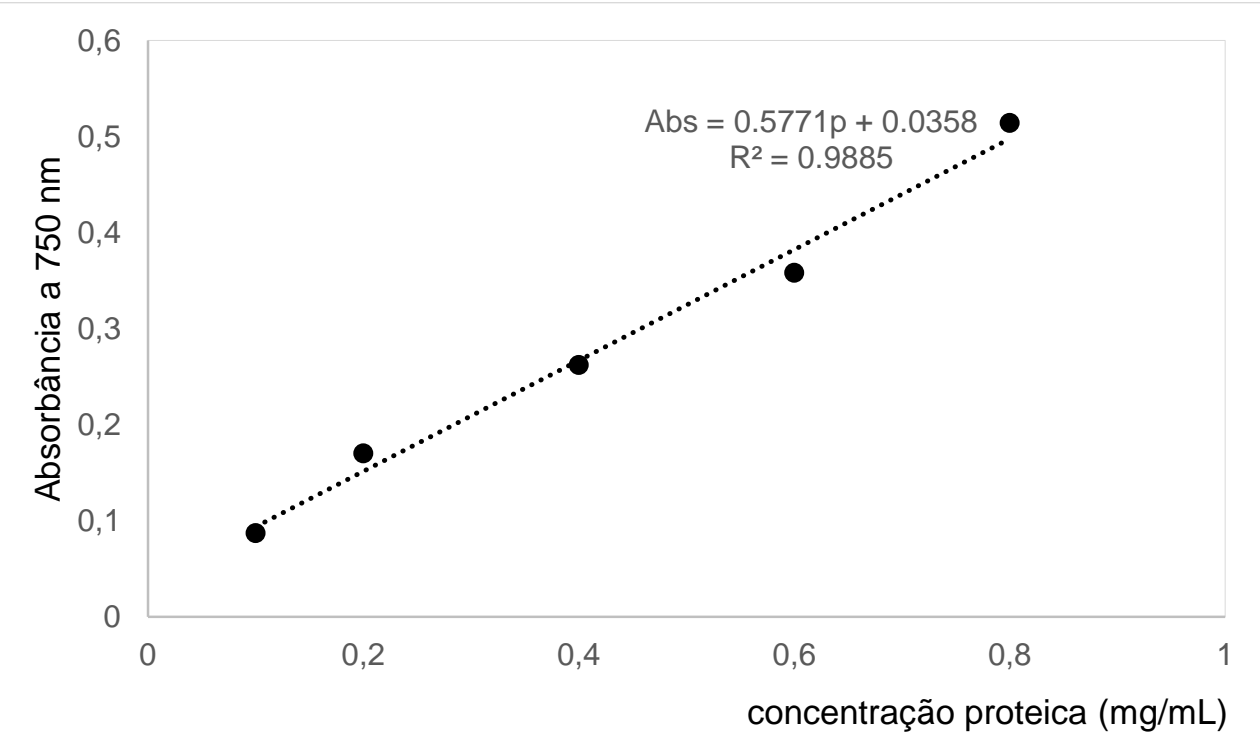

Curva analítica elaborada com a proteína soroalbumina bovina (BSA) para quantificação proteica dos sobrenadantes da centrifugação das dispersões de IPS utilizados no ensaio de hidrofobicidade superficial. 
ANEXO 2 - MODELO DE FICHA APLICADA NO TESTE SENSORIAL

$\underline{\text { logurte batido sabor mel, laranja e cenoura adicionado de } \beta \text {-caroteno microencapsulado }}$

Nome:

Idade:

$20 / 03 / 2014$

Você está recebendo uma amostra de iogurte batido sabor mel, laranja e cenoura adicionado de $\beta$-caroteno microencapsulado. Por favor, prove e avalie a amostra utilizando a escala abaixo para descrever o quanto gostou ou desgostou dos atributos cor, textura, sabor e aceitação global.

Amostra $n^{\circ}$

\begin{tabular}{|l|l|}
\hline Cor & \\
\hline Textura & \\
\hline Sabor & \\
\hline Aceitação Global & \\
\hline
\end{tabular}

1. Detestei

2. Desgostei muito

3. Desgostei regularmente

4. Desgostei ligeiramente

5. Indiferente

6. Gostei ligeiramente

7. Gostei regularmente

8. Gostei muito

9. Adorei 


\section{ANEXO 3 - MODELO DO TERMO DE CONSENTIMENTO PREENCHIDO PELOS PROVADORES}

Termo de consentimento livre e esclarecido

Consentimento formal de participação no projeto de pesquisa: "AVALIAÇÃo SENSORIAL DE IOGURTE COM APLICAÇÃO DE PARTÍCULAS LIPÍDICAS SÓLIDAS ENRIQUECIDAS COM BETACAROTENO".

$$
\begin{aligned}
& \text { Nome: } \\
& \text { Endereço: } \\
& \text { Cidade: }
\end{aligned}
$$$$
\text { CEP: }
$$$$
\text { Fone: }
$$

Justificativa: Uma das tendências fortes na área de alimentos atualmente é a busca por produtos saudáveis, fato este que vem em contraposição à também crescente procura por produtos industrializados, por possuírem, entre outras características, maior estabilidade, fácil preparo ou prontos para o consumo. Nos casos onde o processamento industrial requerido pode prejudicar nutricionalmente o alimento, a busca é pela adição de bioativos naturais que estejam devidamente protegidos. Estes compostos podem vir até a substituir aditivos cuja ingestão é controlada e/ou substituir aqueles que vêm sendo banidos devidos aos efeitos nocivos por consumo prolongado. Um grande desafio é descobrir um compromisso entre a proteção devida do composto ativo durante as etapas de industrialização e distribuição e sua biodisponibilidade no organismo humano após ingeridos. O betacaroteno, o caroteno mais comumente encontrado em alimentos, é um eficiente pro-vitamínico, possui ação antioxidante já foi relatada sua ação na prevenção de doenças coronarianas, cardíacas e alguns tipos de câncer. Neste contexto, e seguindo a busca por sistemas de microencapsulantes que possam ser adicionados com segurança em formulações alimentícias, é que se encontra o presente projeto.

Objetivos do projeto: Avaliar a aceitação sensorial do iogurte aplicado de betacaroteno microencapsulado por partículas lipídicas sólidas estabilizadas com isolado proteico de soja.

Procedimentos: A análise onde seres humanos avaliam diversos atributos de qualidade de alimentos é chamada de

ANÁLISE SENSORIAL. Os procedimentos para execução da análise sensorial nesta pesquisa serão os seguintes:

- Sessenta provadores farão a avaliação sensorial dos produtos.

- Serão testadas formulações de iogurte com diferentes composições das dispersões de betacaroteno

- O provador deverá avaliar (olhar, cheirar, provar) os produtos e responder às perguntas solicitadas na Ficha de Avaliação.

- A duração do teste para cada pessoa será de aproximadamente 5 minutos.

Outras informações:

- O provador pode se recusar a continuar com a avaliação sensorial a qualquer momento, sem penalização alguma e sem prejuizo ao seu cuidado.

- Os provadores não terão qualquer tipo de despesas em decorrência da participação na pesquisa.

- Não há possibilidade de risco ou qualquer tipo de desconforto em função da participação nesta pesquisa, uma vez que todos os ingredientes utilizados nos produtos são inteiramente seguros e serão de boa qualidade e procedência e o processo de fabricação será realizado de acordo com as normas de Boas Práticas de Fabricação. Além disso, a matéria-prima (leite) será pasteurizado e o iogurte armazenado sob refrigeração $\left(7^{\circ}-10^{\circ} \mathrm{C}\right)$ até o momento da realização das análises.

- Em função do exposto no item anterior, não há previsão de indenização em decorrência da participação neste projeto.

- Os testes para avaliação sensorial do iogurte, nos quais os provadores experimentarão os produtos desenvolvidos serão acompanhados pela aluna proponente (Camila Velludo Molina).

- Quaisquer outros esclarecimentos poderão ser solicitados antes, durante e após a pesquisa. Eu,

CPF abaixo assinado, concordo em participar do estudo "AVALIAÇÃO SENSORIAL DE IOGURTE COM APLICAÇÃO DE PARTíCULAS LIPÍDICAS SÓLIDAS ENRIQUECIDAS COM BETACAROTENO" TENhO pleno conhecimento da justificativa, objetivos, benefícios esperados e dos procedimentos a serem executados, bem como da possibilidade de receber esclarecimentos sempre que considerar necessário. Será mantido sigilo quanto à identificação de minha pessoa e zelo a minha privacidade. Ao mesmo tempo assumo o compromisso de seguir as recomendações estabelecidas pelos pesquisadores. Eu li e entendi todas as informações contidas neste documento.

Aluna responsável: Camila Velludo Molina - Eng. de Alimentos.

Contato: camilamolina@usp.br

Pirassununga, de de

Assinatura: 


\section{ANEXO 4 - ESPECIFICAÇÕES DAS MATÉRIAS-PRIMAS (ESTEARINA DE PALMA E GOMA XANTANA)}

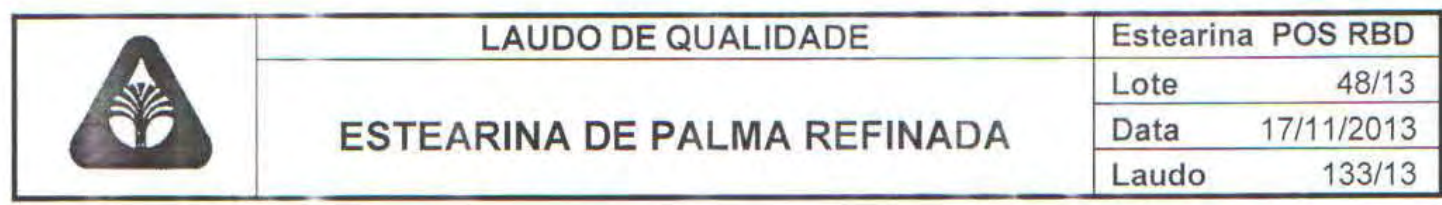

Cliente: USP

Data de Fabricação: 17/12/2012

Prazo de Validade: 12 meses após fabricação.

Aditivos: Isento.

Características:

Fisico Quimicas (AOCS)

\begin{tabular}{|l|c|c|l|c|c|}
\hline \multicolumn{1}{|c|}{ Atributos } & Resultados & Limites & \multicolumn{1}{c|}{ Atributos } & Resultados & Limites \\
\hline Acidez (\% Palmitico ) & 0,041 & $\leq 0,05$ & SFC à $10^{\circ} \mathrm{C}$ & 69,00 & $74 \pm 5$ \\
\hline I.Peróxidos ( $\mathrm{mEq} / \mathrm{kg})$ & 0,553 & $\leq 1,0$ & SFC à $20^{\circ} \mathrm{C}$ & 48,85 & $53 \pm 5$ \\
\hline Cor Lovibond Red 5 $1 / 4$ & 2,3 & $\leq 4,0$ & SFC à $25^{\circ} \mathrm{C}$ & 40,74 & $42 \pm 5$ \\
\hline Ponto de Fusão $\left({ }^{\circ} \mathrm{C}\right)$ & 52,0 & $49-52$ & SFC à $30^{\circ} \mathrm{C}$ & 35,87 & $32 \pm 5$ \\
\hline Índice de lodo $($ wijjs $)$ & 39,48 & $36-42$ & SFC à $35^{\circ} \mathrm{C}$ & 28,00 & $23 \pm 5$ \\
\hline Sabor & Neutro & Neutro & SFC à $40^{\circ} \mathrm{C}$ & 21,54 & $18 \pm 5$ \\
\hline
\end{tabular}

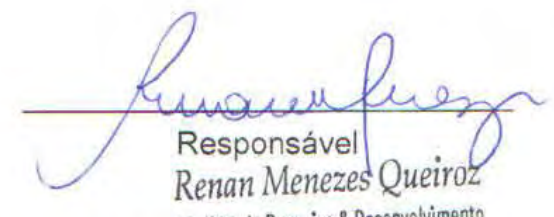

Analista de Pessuisa \& Desenvolvinento

Escritório: Al. Santos, 466 - $10^{\circ}$ Andar - Cerqueira César - CEP 01418 - 000 Fone: 011 - 3175- 5465 Săo Paulo-SP E-mail: comercial@agropalma.com.br Fábrica: Rod Arthur Bernardes, 5555 - Tapană - CEP 66825 - 000 Fone 091 - 4009-8000-Belém - Pa - E-mail: tecnico@agropalma.com.br 
GUMS \& SYSTEMS DIVISION

\section{GRINDSTED $®$ Xanthan 80}

\section{Descrição}

GRINDSTED® Xanthan 80 é uma goma xantana granulada de grau alimentício que é particularmente usada como espessante e estabilizante. $\mathrm{O}$ tamanho da partícula é de 80 mesh e assegura um grau rápido de hidratação, fácil manipulação e aplicação em produções normais de alimentos.

\section{Áreas de aplicação}

É uma goma solúvel a frio e apresenta sinergia com goma guar e goma jatai.

Beneficios potenciais

- Agente de suspensão para sólidos e gotas de azeite

- Emulsão efetiva e estabilização da espuma

- Alta viscosidade em baixas concentrações com comportamento pseudoplástico (diluição)

- Efeito anti-sinerése

- Ausência de tixotropia

- Estável tanto em soluções ácidas como alcalinas

- Altamente resistente a temperatura

- Compativel com soluçōes que contém altas concentraç̄es de vários sais.

\section{Dosagens}

As seguintes diretrizes gerais podem ser dadas:

Molhos para salada

Mistura para bolos

Molhos

Relish

Recheios de fruta

Bebidas de frutas

Molho "cole slaw"

Sopas instantâneas

(secas)

$0,15-0,50 \%$

$0,05-0,25 \%$

$0,10-0,30 \%$

$0,10-0,25 \%$

$0,03-0,15 \%$

$0,05-0,15 \%$

$0,15-0,25 \%$

$0,30-0,50 \%$

\section{Instruções de uso}

Formulações especificas e informações sobre o processamento podem ser obtidas se requisitadas.

\section{Especificações físico-químicas}

(Métodos de análise disponiveis se requisitados)

Cor

Umidade

pH (solução 1\%)

Tamanho de partícula

Creamy - white$$
6-12 \%
$$

$6-12 \%$
$6,0-8,0$

min. $95 \%$ passa através de $180 \mu \mathrm{m}$ (mesh 80

Tamanho de particula $\min .99,5 \%$ passa através

Viscosidade$$
\text { de } 250 \mu \mathrm{m} \text { (mesh } 60 \text { ) }
$$

$24^{\circ} \mathrm{C}, 1 \% \mathrm{KCl}$ (Brookfield LVT, $60 \mathrm{rpm}$, spindle 3)

\section{Especificações microbiológicas}

Contagem total em placa

Bolores e leveduras $100 \mathrm{UFC/g}$

Salmonela

usente em 25

E. coli

ausente em $5 \mathrm{~g}$

\section{Especificações de metais pesados}

Metais pesados (como $\mathrm{Pb}$ ) máx. $20 \mathrm{mg} / \mathrm{Kg}$ Chumbo $(\mathrm{Pb})$

Arsênico (As)

Cádmio (Cd)

máx. $2 \mathrm{mg} / \mathrm{Kg}$

máx. $1 \mathrm{mg} / \mathrm{Kg}$

máx. $1 \mathrm{mg} / \mathrm{Kg}$ 